\title{
Zmiany w krajobrazie rolniczym Mazowsza i ich wpływ na wartości wypoczynkowe krajobrazu wynikające z obecności ptaków kurowatych (Phasianidae)
}

\author{
Pamięci Janusza Szymczyka
}

\section{Karolina Pietrzykowska, Jerzy Wojtatowicz}

\section{STRESZCZENIE}

W artykule podjęto się próby ukazania jak działania na poziomie planistycznym i gospodarki rolnej wpływają na wartości wypoczynkowe krajobrazu, wynikające z zachowania ptaków kurowatych. Cel ten zrealizowano na przykładzie trzech gatunków związanych z agrocenozami: kuropatwy, przepiórki i bażanta. W szczególności uwzględniono dostępność pokarmu i siedlisko ich życia. Dokonano analizy zmian i ich przyczyn w kontekście zarówno Polski, jak i Mazowsza. Wybrano te, które w sposób istotny wpływają na kształtowanie się obecnej struktury ilościowej omawianych gatunków ptaków, tj.: strukturę użytkowania terenów rolnych, chemizację, nawożenie i mechanizację. Do realizacji celu głównego i celów pośrednich, rozwiązywanych na poszczególnych etapach pracy, stosowano metody dedukcyjne używane w architekturze krajobrazu. Stawiano hipotezy, które weryfikowano poprzez analizę literatury w określonym aspekcie. Główną hipotezą do zbadania było określenie, czy postęp w gospodarce rolnej, uwzględniający wielofunkcyjne wykorzystanie krajobrazu, wspomagany metodami planistycznymi, może przyczynić się do rozwoju walorów wypoczynkowych krajobrazu wynikających z ochrony ptaków kurowatych. Potwierdzono, że działania na poziomie planistycznym nie odpowiadają na potrzeby związane z ich ochroną. Analiza związków i zależności między ludźmi, gatunkami zwierząt i ich środowiskiem wykazała, że mogą być one zarówno pozytywne, jak i negatywne w każdym z rozważanych przypadków. Porównanie okresu od lat 90 . XX w. do roku 2017 potwierdziło postępującą intensyfikację rolnictwa. Zestawienie pokarmu roślinnego pozwoliło na wykazanie, że omawiane kuraki żywią się w sumie 247 roślinami. 17 z nich stanowi pokarm dla trzech gatunków, a 55 dla dwóch. Podział roślin na kategorie pozwolił na wykazanie, że największą bazę żerową dla kuropatwy i bażanta stanowią rośliny krajobrazowe $(55 \%, 49,7 \%)$, użytkowe $(50,5 \%, 57,4 \%)$ i ozdobne $(39,3 \%$, $42 \%)$. Dla przepiórki zaś chwasty (56,3\%), rośliny użytkowe (41,8\%) i zagrożone na Mazowszu (32\%). Chwasty w przypadku kuropatwy i bażanta stanowiły $38,2 \%$ i $29,4 \%$, a rośliny zagrożone ponad $14 \%$ wszystkich zjadanych roślin. Rośliny upraw rolniczych stanowiły $23,5 \%$ w przypadku kuropatwy, przepiórki $18,1 \%$, a bażanta $14,4 \%$ ich bazy żerowej.

W odpowiedzi na zaistniałe problemy autorzy zauważają potrzebę każdorazowego projektowania indywidualnych modeli krajobrazowo-przestrzennych dla poszczególnych gmin. Modele takie powinny w przypadku kuropatwy, w szczególności uwzględniać pasmowy układ podstref. Istotne jest także, by uwzględniały one miejsca schronień, gniazdowania i zdobywania pokarmu.

Słowa kluczowe: modele krajobrazowo-przestrzenne, krajobraz wiejski, wypoczynek, pokarm roślinny, przepiórka, kuropatwa, bażant 


\section{Wstęp}

Nieodłączną cechą krajobrazu są zmiany, jakie zachodzą pomiędzy poszczególnymi jego składnikami. Odbywać się one mogą w różnym tempie i skali oraz być powodowane siłami natury lub działalnością człowieka ${ }^{1}$. W artykule skupiono się na terenach rolniczych, które zajmują 52,4\% powierzchni Polski². Stanowią one zatem istotny obszar w skali kraju z punktu widzenia nie tylko ochrony przyrody i krajobrazu, ale także zaspokajania potrzeb m.in. wypoczynkowych ludzi.

W tym przypadku problematykę ochrony i kształtowania krajobrazu rozważono z punktu widzenia architekta krajobrazu, który planując czy projektując tereny wypoczynkowe uwzględnia potrzeby ludzi w tym zakresie. Podjęcie tej tematyki uzasadnione jest koniecznością pogodzenia wielu wymagań będących ważnym walorem turystyki na terenach otwartych. Należą do nich m.in.: produkcja rolnicza, ochrona dziedzictwa kulturowego i przyrodniczego. Ważną rolę w kontekście wypoczynku odgrywają zarówno obszary chronione, jak i gatunki objęte ochroną prawna, takie jak ptaki.

W zależności od potrzeb ludzi i wyznaczonego priorytetu, istniejące elementy w różnych przedziałach czasowych zwiększają lub tracą swoją wartość. Komponenty krajobrazu, sprzyjające stawianym celom i przynależące do funkcji podstawowej zwykle stając się istotne, wypierają pozostałe. Elementy kolidujące gina, pozostałe obojętne dla niej powiększają swoją liczebność i areał występowania lub ustępują.

Na terenach wiejskich podstawowym celem aktywności ludzkiej jest produkcja rolna. Pozostałe, do których należą m.in. ochrona przyrody i wypoczynek, koegzystują z nią często ponosząc dotkliwe szkody. Analizę tej relacji i czynników na nią wpływających przeanalizowano w niniejszym artykule, ze szczególnym uwzględnieniem Mazowsza.

Omówiono, w jaki sposób poszczególne działania w krajobrazie rolniczym, związane z planowaniem przestrzennym i intensyfikacją rolnictwa, wpływają na faunę i florę tych terenów, a także ich postrzeganie. Za przykład posłużyły wybrane gatunki ptaków z rodziny kurowatych, które uznano za charakterystyczne przez swoje ścisłe powiązanie z tymi terenami, zarówno w aspekcie kulturowym³ ${ }^{3}$ jak i przyrodniczym.

\footnotetext{
${ }^{1}$ Powolne - wzrost rośliny, szybkie - powódź, skala mikro - drzewo, skala makro - określony typ krajobrazu, powodowane siłami natury - drzewo złamane przez uderzenie pioruna, powodowane działalnością człowieka - wypalanie traw.

${ }^{2}$ Stan na 1 czerwca 2018 r. [GUS 2018b].

${ }^{3}$ Myślistwo, kulinaria, sztuka użytkowa, malarstwo np.: J. Chełmoński „Kuropatwy na śniegu”, J. Cybis „Bażanty”, F. Goya „Polowanie na przepiórki”, A. Pisano „Madonna z przepiórką”.
} 


\section{Cel, zakres pracy, metodyka}

Celem pracy było pokazanie, jak działania na poziomie planistycznym i gospodarki rolnej wpływają na wartości wypoczynkowe krajobrazu, wynikające z zachowania ptaków kurowatych. Jako przykład posłużyły wybrane gatunki ptaków z rodziny kurowatych: kuropatwa Perdix perdix L., przepiórka Coturnix coturnix L. oraz bażant Phasianus colhicus L.

Na potrzeby postawionego celu omówiono wybrane działania wpływające na krajobraz rolniczy podejmowane $\mathrm{w}$ planowaniu przestrzennym oraz rolnictwie. Analizując literaturę z zakresu planowania przestrzennego, zwrócono uwagę na modele zagospodarowania terenów rolniczych.

W szczególności wzięto pod uwagę ekotony i pasma śródpolne. Modele te mogłyby być wykorzystane do ochrony badanych gatunków oraz rozwoju agroturystyki [Bartman 1974, s. 56-76; Wuczyński i in. 2011, s. 202-209]. Działania w odniesieniu do rolnictwa omówiono w kontekście Polski i Mazowsza. Skoncentrowano się na zmianach: powierzchni użytków rolnych, poziomu nawożenia, zużycia środków ochrony roślin oraz mechanizacji. Do realizacji celu głównego i celów pośrednich, opracowywanych na poszczególnych etapach, stosowano metody dedukcyjne używane w architekturze krajobrazu. Stawiano hipotezy, które weryfikowano poprzez analizę literatury w określonym aspekcie. Główną hipotezą do zbadania było określenie, czy postęp w gospodarce rolnej wspomagany metodami planistycznymi, może przyczynić się do rozwoju walorów wypoczynkowych w krajobrazie wiejskim. Mając na względzie ten aspekt przeprowadzono badania roślinnej bazy pokarmowej ptaków, którą zestawiono w tabelach. Podano w nich nazwę polską i łacińską. Przeprowadzono ich analizę pod kątem wartości krajobrazowych, walorów ozdobnych, a także innych cech, które w mniejszym lub większym stopniu wpływają na wypoczynek. Na tej podstawie wyróżniono kategorie, które zdefiniowano poniżej.

Rośliny krajobrazowe (Rk) - rośliny wyróżniające się w krajobrazie; dominujące w polu widzenia ze względu na liczebność (np. zboża nadające zbiorowiskom swoisty wygląd), pokrój, barwę. Zwykle reprezentują zbiorowiska roślinne pochodzenia kulturowego.

Rośliny ozdobne (Ro) - rośliny wyróżniające się estetycznymi cechami plastycznymi, dużymi walorami dekoracyjnymi, takimi jak piękne i ciekawe kwiaty, owoce, ulistnienie, zabarwienie pędów, pokrój. W ich kwalifikacji wspomagano się publikacjami [Krause i in. 2004; Seneta, Dolatowski 2009].

Rośliny zagrożone na Mazowszu (RzM) - rośliny zagrożone wyginięciem w krajobrazie rolniczym Mazowsza. Gatunki określono na podstawie literatury: [Warcholińska 1987, s. 225-231; Warcholińska 1998, s. 115-130; Jakubowska-Gabara, Kucharski 1999, s. 55-74; Bomanowska 1998, s. 107-112; Michalska-Hejduk, Bomanowska 2009, s. 107-112].

Rośliny zagrożone (Rz) - gatunki wymienione na Czerwonej liście roślin zagrożonych [Mirek, Zarzycki 2006] o stopniach narażenia: Ex - wymarłe i zaginione, E - wymierające, krytycznie zagrożone, V - narażone, zagrożone wyginięciem, I - posiadające nieokreślony stopień zagrożenia. Do grupy tej zaliczono także gatunki objęte ochroną gatunkową ścisła, jak i częściową. 
Chwasty (Ch) - rośliny powszechnie uważane za niepożądane w składzie uprawy rolnej, np. polowej, ogrodowej, łąkowej.

Rośliny upraw rolniczych (Rur) - rośliny zielne związane z uprawami rolniczymi i ogrodniczymi, a także rośliny drzewiaste krótkowieczne z uwagi na przyjętą technologię upraw sadowniczych.

Rośliny użytkowe (Ru) - rośliny dziko żyjące i uprawiane przez człowieka. Wykorzystywane m.in. w przemyśle stolarskim, kosmetycznym, farmaceutycznymi itd. [Podbielkowski 1985].

Przynależność do kategorii pominięto, gdy w materiale źródłowym podano jedynie nazwę rodziny lub rodzaju, a także w przypadku roślin o cechach niewyróżniających się.

W kolumnie „źródła” przedstawiono dane pochodzące z literatury i obserwacji własnych. Dane z literatury podano na drugim miejscu, po danych pochodzących z obserwacji terenowych. Ułożono je chronologicznie, a nie w kolejności liczb porządkowych, stosując następujące skróty:

1. Oznaczenia rodzaju pokarmu: Bk - bulwy korzeniowe, $\mathrm{K}$ - kwiaty, Ko - korzenie, L liście, $\mathrm{N}$ - nasiona, $\mathrm{O}$ - owoce, Pą - pąki, Pę - pędy, Zcz - zielone części.

2. Oznaczenia miejsc obserwacji: $\mathrm{k}$ - ptaki w niewoli, w klatce, w wolierze, Emil. - Emilianów k. Radzymina, Kacz. - Łazy Kaczeniec k. Łochowa, Klau. - Terenowa Stacja Ochrony Przyrody i Krajobrazu Wyższej Szkoły Ekologii i Zarządzania w Klaudynie, gm. Stare Babice, Urs. - Park pałacowy Szkoły Głównej Gospodarstwa Wiejskiego w Warszawie przy ul. Nowoursynowskiej.

3. Autorzy obserwacji: JD - Jerzy Derlicki, JW - Jerzy Wojtatowicz, KP - Karolina Pietrzykowska, WT - Włodzimierz Tymiński.

Z uwagi na szereg zmian w taksonomii ptaków i roślin, a także zmian w nomenklaturze zoologicznej i botanicznej, jakie miały miejsce od końca XIX w., dane z literatury podawano z reguły w wersji uwspółcześnionej. Niezbędne zmiany nazewnictwa starano się ujednolicić w sposób konsekwentny, wedle wskazań Katalogu Faunistycznego [Bogdanowicz, Chudzicka, Pilipiuk, Skibińska 2014] i The Plant List [http://www.theplantlist.org/]. Nazwy polskie weryfikowano wedle wskazań Atlasu Roślin Polski [atlas-roslin.pl].

Rośliny przynależne do poszczególnych kategorii zliczono uwzględniając sumarycznie gatunki i niższe grupy systematyczne. Podano także rośliny, które stanowią pokarm dla trzech i dwóch z omawianych gatunków ptaków kurowatych.

\section{Wpływ planowania przestrzennego na zmiany w krajobrazie rolniczym}

Specyfika krajobrazów wiejskich, wynikająca z ich różnorodności, ma wartość nie tylko z punktu widzenia estetycznego czy wypoczynkowego. Ich bogactwo ekosystemowe stanowi układ ekologiczny ważny także dla ochrony przyrody. Ważność ta znajduje poparcie w przyjętej przez Polskę zasadzie zrównoważonego rozwoju ${ }^{4}$, która leży u podstaw pla-

\footnotetext{
${ }^{4}$ Konstytucja Rzeczypospolitej Polskiej, 1997, art. 5 [Chylarecki i in. 2018].
} 
nowania przestrzennego. Występujące w tym zakresie problemy rozpatrzono na poziomie krajowym i lokalnym.

Na poziomie krajowym, na pierwszy plan wysuwa się zbyt duża liczba przepisów prawa mająca wpływ na proces planowania, co utrudnia gospodarowanie przestrzenią [https:// www.nik/gov.pl/aktualności/nik-o-systemie-gospodarowania-przestrzenia-gmin.html]. Istotna jest także kwestia dopłat, których nie ma w przypadku kształtowania krajobrazu, i które są dla rolników wyższe w przypadku gruntów ornych niż łąk [Ulbrych 2009, s. 265271]. Powyższe powoduje poważne konsekwencje dla ochrony przyrody. Niszczenie łąk jest równoznaczne z utratą cennych roślin, które stanowią źródło pożywienia, schronienia i lęgów dla wielu gatunków zwierząt, w tym ptaków. Zjawisko to jest tym bardziej niepokojące, że powiększające się grunty orne przyczyniają się do coraz częściej obserwowanej likwidacji dróg, miedz i zadrzewień przydrożnych, przywodnych i śródpolnych ${ }^{5}$ (ryc. 1).

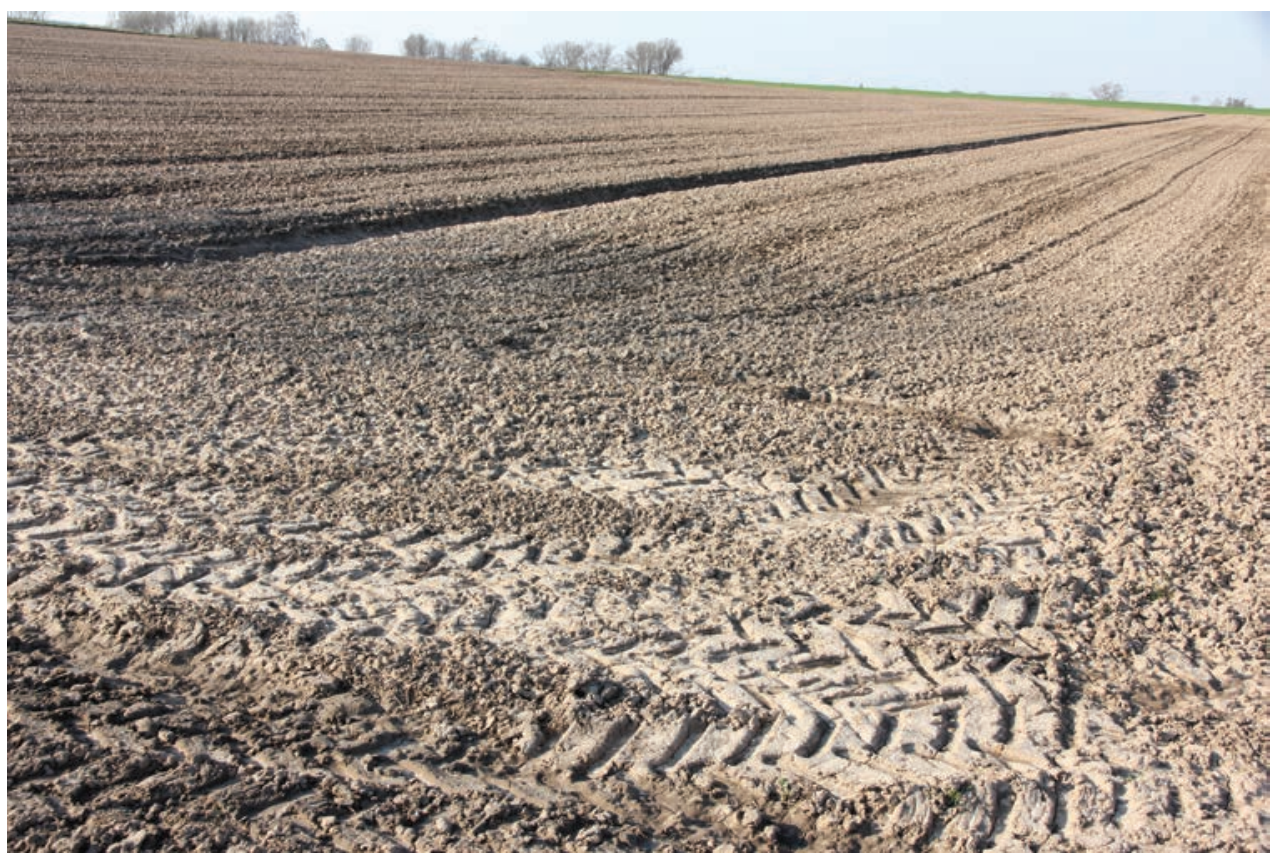

Ryc. 1. Grunty orne koło Bronowa, województwo mazowieckie

Fot. J. Wojtatowicz

\footnotetext{
${ }^{5}$ Np.: na Mazowszu, nad Narwią i Biebrzą między Bronowem i Wizną, na Podlasiu na wschód od Wizny między Rusią, Burzynem i Klimaszewnicą.
} 
Ponadto tylko 30\% gmin dysponuje miejscowymi planami zagospodarowania przestrzennego, które są zwykle nieaktualne, fragmentaryczne i wykonywane szablonowo. Powyższe potwierdzają przeprowadzone w latach 2010-2016 kontrole w 360 urzędach gmin i 50 starostwach powiatowych na terenie Polski. W 37\% przypadków nie wykonano opracowań ekofizjograficznych. Ich brak powoduje możliwość zagospodarowania terenów ze szkodą dla środowiska oraz prawdopodobieństwo błędów w ujęciu jego ochrony w przygotowanych studiach. W 26\% kontrolowanych jednostek, w tym tych położonych w województwie mazowieckim, np.: Grodzisk Mazowiecki, Piaseczno, Konstancin Jeziorna, stwierdzono, że zawarte dane o obiektach ochrony przyrody były nieaktualne. Ponadto, w gminie Konstancin Jeziorna studium uwarunkowań i kierunków zagospodarowania przestrzennego gminy nie zawierało wymaganych elementów, takich jak określenie konieczności ochrony wód i ziemi przed zanieczyszczeniami w związku z prowadzeniem gospodarki rolnej. Nie uwzględniło ono także obszaru NATURA 2000 - PLB 14004 „Dolina Środkowej Wisły” [NIK 2016].

Nieprzykładanie wagi nawet do obszarów i obiektów chronionych ${ }^{6}$ oraz brak indywidualnych modeli dostosowanych do danej wsi powoduje utratę cennych wartości przyrodniczych i dewastację krajobrazu [Bogdanowski 1999, s. 25-31; Żarska 2006]. Przyczynia się do tego także wspomniane powyżej scalanie gruntów, powodujące niszczenie takich elementów jak zadrzewienia czy zakrzewienia oraz niekontrolowana zabudowa [Kupidura, Łuczewski, Kupidura 2011].

Ten ostatni aspekt wynika z nieprawidłowości w ustawie o Planowaniu i Zagospodarowaniu Przestrzennym [https://www.nik.gov.pl/aktualnosci/nik-o-systemie-gospodarowania-przestrzenia-gmin.html]. Pozwala ona bowiem na niemal nieograniczoną zabudowę wszelkich terenów, które nie mają opracowanych planów miejscowych, w drodze decyzji o warunkach zabudowy. Za przykład posłużyć może otulina Kampinoskiego Parku Narodowego, gdzie rocznie wydawanych jest kilkanaście projektów decyzji we wsiach parkowych: Dąbrowa, Truskaw, Izabelin, Janówek, Truskawka [Michalska-Hejduk, Bomanowska 2009]. Innym tego przykładem jest obszar między Zielonką i rzeką Długa który był bardzo ważny z punktu widzenia migracji zwierząt i został zabudowany?

Ekspansywna zabudowa wsi powoduje niszczenie cennych przestrzeni, które powinny być kształtowane miejscowymi planami zagospodarowania przestrzennego. Na uwagę w tych rozważaniach zwraca fakt, że zasada zrównoważonego rozwoju dotyczy zarówno terenów chronionych, jak i pozostałych, które tym bardziej są pomijane. Fakt ten zauważają m.in. Marks i Markowski [2012, s. 145-154], Słojewski [1976]. Powyższe potwierdza także Żarska [2006], która stwierdza, że „koncentrowanie się wyłącznie na przyrodniczych obszarach chronionych jest z dużym prawdopodobieństwem niewystarczające do wstrzymania procesu wymierania dzikich gatunków wskutek działalności człowieka" [Żarska 2006, s. 148].

Poprawność działań w tym zakresie ilustrują przykłady z krajów Europy zachodniej, w których kwestie związane z kształtowaniem krajobrazu obszarów wiejskich stanowią

\footnotetext{
${ }^{6}$ Są to użytki ekologiczne, zespoły przyrodniczo-krajobrazowe.

${ }^{7}$ Teren ten, w pierwotnym projekcie obszaru chronionego krajobrazu, stanowił bardzo ważną jego część.
} 
istotny element planowania przestrzennego. Na cele związane z ochroną środowiska i krajobrazu przeznacza się 10\% danego terenu, a plany tworzy się indywidualnie. W Holandii prace studialne opracowują interdyscyplinarne zespoły złożone z architektów krajobrazu, ekologów, planistów itd. Działania tzw. urządzeniowo-rolne podzielone są na poziomy. Przedstawia się w nich ustalone funkcje, projektowane struktury krajobrazu oraz rozwiązania techniczne w postaci planów, rzutów, szczegółów nasadzeń itp. Podobne rozwiązania stosowane są także we Francji czy Bawarii [Żarska 2006].

Posługując się tylko narzędziami planistycznymi trudno jest rozwiązywać wiele problemów ochrony zwierząt. Z pewnością jest to możliwe i celowe, gdy skala tych opracowań na to pozwala. Dotyczy to np. ochrony gatunków z bardzo dużymi rewirami lęgowymi, u których noclegowiska i żerowiska oddalone są od siebie na odległość wielu kilometrów. Znaczna część tych problemów może być rozwiązana przez projektanta. Są też jednak i takie, które wymagają współpracy z planistą. Dotyczy to na przykład kształtowania siedlisk ptaków, które w ciągu roku zmieniają miejsca pobytu ze względu na dostępność pokarmu i miejsc lęgowych. Kierując się potrzebami racjonalnej ochrony konieczna jest ścisła integracja działań planisty i projektanta. Istotna w tym zakresie jest także współpraca z decydentem czy inwestorem, którzy rozumieją potrzebę harmonijnego rozwoju gminy czy działki.

W przypadku ptaków daleko migrujących, jak np. gęsi zbożowej, bociana białego czy wikłacza czerwonodziobego [Pinowski 2018] potrzebna jest współpraca międzynarodowa. Ważne w niej miejsce powinni zajmować planiści, projektanci oraz właściciele terenów, na których żyją cenne i zagrożone gatunki. W tych rozważaniach istotne są także gatunki pospolite, które już dziś zmniejszają swoją liczebność.

Przedstawione powyżej problemy uznać należy za pierwszoplanowe, bez rozwiązania których możliwość realizacji zrównoważonego rozwoju poddana zostaje w wątpliwość.

\section{Wpływ powiązań między obszarami wiejskimi, ptakami i wypoczynkiem}

Planując czy projektując tereny wypoczynkowe na wsi, które mają chronić miejscową faunę, należy mieć na uwadze wzajemne powiązania pomiędzy obszarem zamieszkiwanym przez ludzi i dzikie zwierzęta. Taki układ wynika z wielofunkcyjności wsi. Z jednej strony stanowi ona miejsce produkcji roślin uprawnych, a z drugiej jest terenem wypoczynku ludzi i zamieszkiwania swoistej fauny, w tym ptaków. Analiza związków i zależności zachodzących pomiędzy terenem, człowiekiem i określonym gatunkiem zwierzęcia powinna być pierwszym krokiem w podejmowanych działaniach planistycznych i projektowych. Relacje te rozważać należy zarówno w aspekcie pozytywnym, jak i negatywnym.

Podczas rozpatrywania wzajemnych relacji, z punktu widzenia architekta krajobrazu, posłużono się schematem analizy związków i zależności. Pozwala on od etapu wstępnych prac przedprojektowych na opracowanie ramowego planu działań planistycznych, projektowych czy decyzyjnych dla danego obszaru. Rozważając korzystny wpływ terenu dla określonego gatunku uwidacznia się wiele zadań wynikających z konieczności zachowania 
wartości przyrodniczych i kulturowych. Zalicza się do nich: dostosowanie do przepisów ochrony przyrody i środowiska, zachowanie bioróżnorodności, utrzymanie swoistych cech krajobrazowych i walorów turystycznych. Analizując znaczenie zwierząt w kompleksowym ujęciu zadań ochronnych w planowaniu czy projektowaniu, należy uwzględnić korzyści wynikające z ograniczania roślin niepożądanych w rolnictwie, szkodników, roślin uprawnych, czy zapylania kwiatów ${ }^{8}$. W przypadku turystyki pozytywny wpływ wynika z ich obecności, różnorodności i możliwości ich obserwacji. Istnienie ptaków i innych zwierząt, np. ryb, płazów cechujących się interesującym wyglądem, miłym i donośnym głosem zawsze podnosi walory turystyczne terenu (ryc. 2).

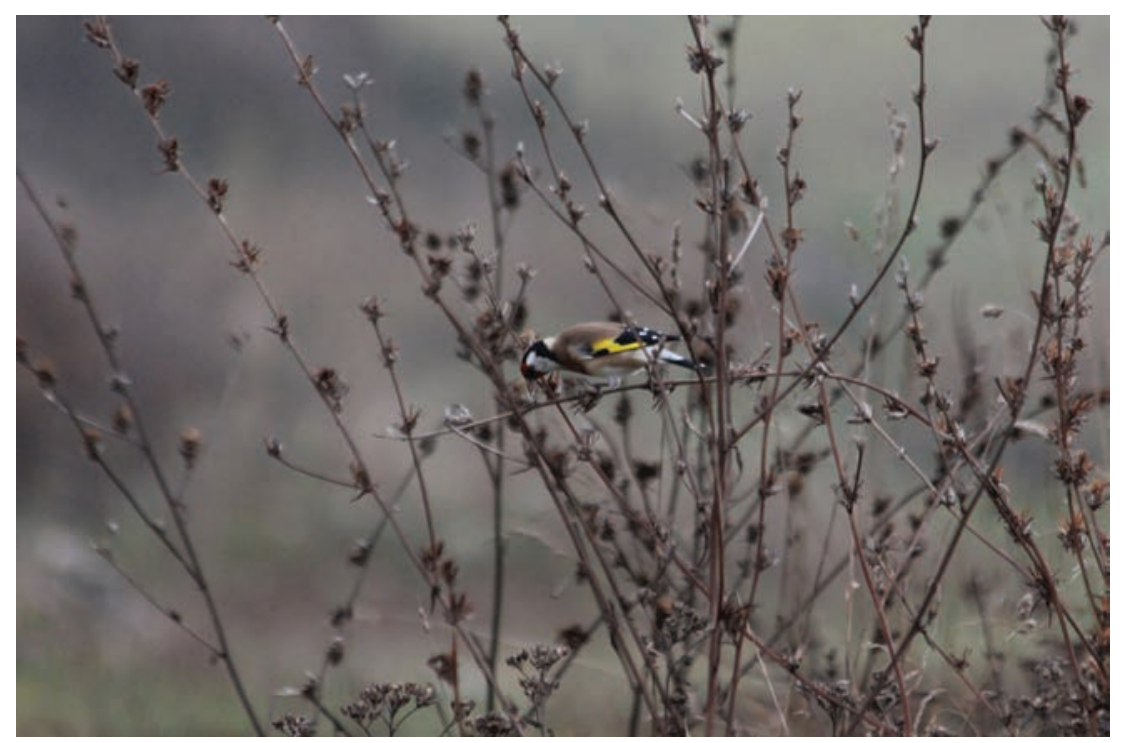

Ryc. 2. Szczygieł zjadający nasiona cykorii

Fot. J. Wojtatowicz

Biorąc pod uwage potrzeby ptaków i innych zwierząt w odniesieniu do środowiska należy uwzględnić miejsca lęgów, schronień, noclegowisk, tokowisk, wodopojów i miejsc kąpieli suchej i mokrej ${ }^{9}$.

W odniesieniu do turystyki wymagany jest spokój, zwłaszcza dla gatunków płochliwych. Na wyjątkową uwagę zasługują obszary odwiedzane masowo w okresie lęgów ptaków. Są one miejscem, w którym giną pisklęta z głodu, a jaja z powodu wychłodzenia. Najczęściej są to obszary atrakcyjne do wypoczynku nad woda, miejsca zawodów wędkarskich i tereny poza miastem.

\footnotetext{
${ }^{8}$ Pozytywny wpływ dla producentów nasion, owoców i pszczelarzy.

${ }^{9}$ Tokowiska i miejsca walk, trybuny, miejsca śpiewu i wydawania innych dźwięków.
} 
Analizując wpływ zwierząt na gospodarkę rolną należy mieć przede wszystkim na względzie szkody w uprawach oraz możliwość przenoszenia chorób groźnych dla zwierząt domowych. Przenoszenie chorób, masowe pojawianie się komarów, gzów, kleszczy, meszek to najczęściej spotykane niekorzystne oddziaływania zwierząt na wypoczywających ludzi.

Korzystny wpływ obszarów wiejskich na zwierzęta wynika z możliwości realizacji wymagań życiowych. Dla turystyki natomiast to przede wszystkim możliwości korzystania z walorów turystycznych odmiennych od tych, z którymi obcują oni na co dzień.

Niekorzystny wpływ rolnictwa na faunę wynika ze zmian powodowanych przez intensyfikację produkcji, $\mathrm{w}$ tym chemizację, mechanizację oraz produkcję wielkoobszarową. Szczególnie dotyczy to tych, które nie uwzględniają naturalnych cykli życiowych dzikich zwierząt, a także niszczenia tras ich wędrówek (ryc. 3).

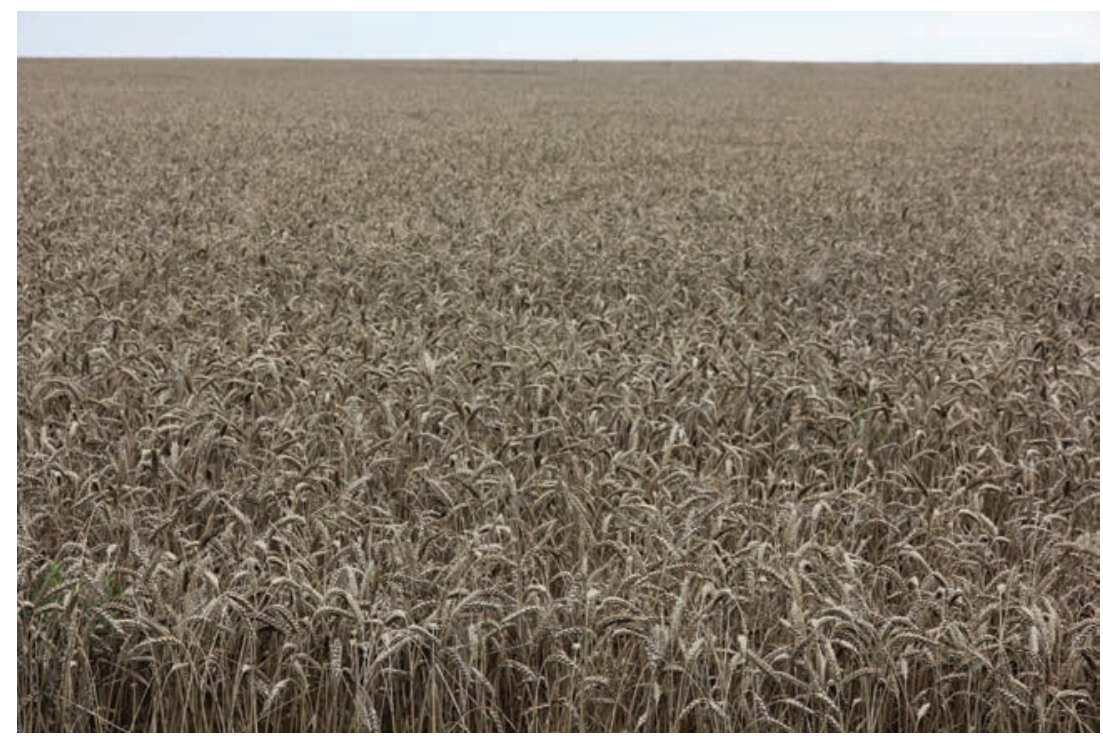

Ryc. 3. Pole pszenicy

Fot. J. Wojtatowicz

W kontekście turystyki niekorzystny wpływ rolnictwa przejawia się głównie w degradacji walorów wypoczynkowych. Obejmuje on także używanie środków chemicznych niebezpiecznych dla zdrowia i życia ludzi.

Korzystny wpływ turystyki na obszary wiejskie to głównie możliwość pozyskania pozaprodukcyjnych środków materialnych oraz zwiększenie dbałości o ochronę walorów przyrodniczych i kulturowych.

Korzystny wpływ turystyki dla dzikich zwierząt to działania na rzecz ich ochrony. 


\section{Intensyfikacja rolnictwa w krajobrazie Mazowsza i jej wpływ na ptaki kurowate}

W analizie zmian, jakie zaszły na terenie Polski i Mazowsza od lat 90. do roku 2017 potwierdzono stale postępującą intensyfikację rolnictwa. Obejmuje ona m.in. wzrost powierzchni użytków rolnych ${ }^{10}$, zużycia nawozów mineralnych ${ }^{11}$ oraz pestycydów ${ }^{12}$, a także mechanizację ${ }^{13}$. Tendencję tę przedstawiają poniże ryciny (ryc. 4-7).

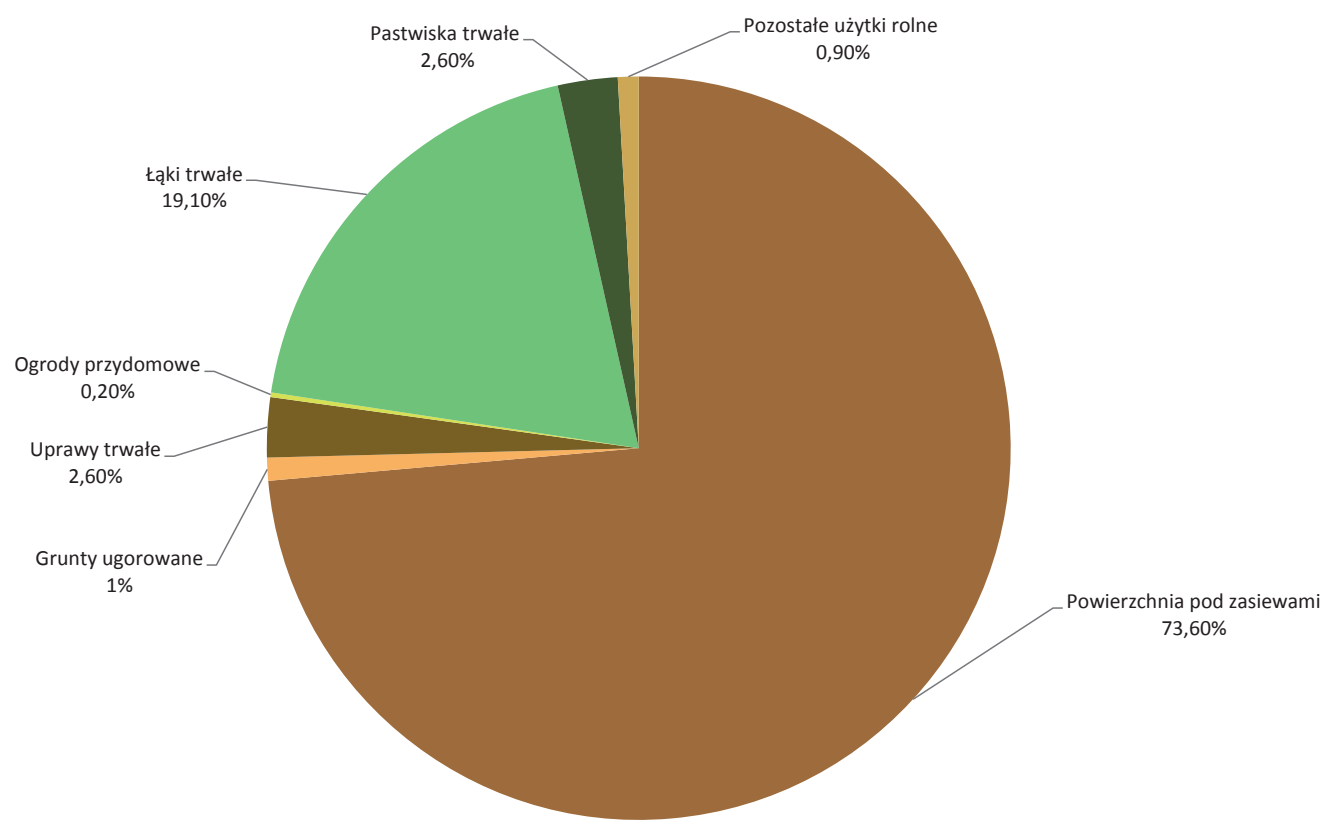

Ryc. 4. Użytki rolne w gospodarstwach rolnych ogółem na terenie Polski

Źródło: GUS 2018

\footnotetext{
${ }^{10}$ W Polsce grunty orne stanowity kolejno w 1990 r. - 46\%, 2000 - 45\%, 2017 r. - 75\% [GUS 2001; GUS 2017]. ${ }^{11}$ W Polsce -1990 r. - 3028,7 tys. t, 2000 r. - 1526,5 tys. t, 2017 r. - 2049,8 tys. ton, w województwie mazowieckim - 2000 r. $-179,141$ tys. ton, 2017 r. $-227,5$ tys. ton [GUS 2001; GUS 2017].

${ }^{12}$ W Polsce - 1990 r. - 19435 t, 2000 r. - 22164 t, 2017 r. - 71446 t [GUS 2001; GUS 2017].

${ }^{13}$ W Polsce, żywa siła pociągowa - 1990 r. - 9,7\%, 2000 r. - 4,7\%, 2016 r. - nie odnotowano, w województwie mazowieckim - 2000 r. - 6,5\%, 2016 r. - nie odnotowano [GUS 2001; GUS 2017].
} 


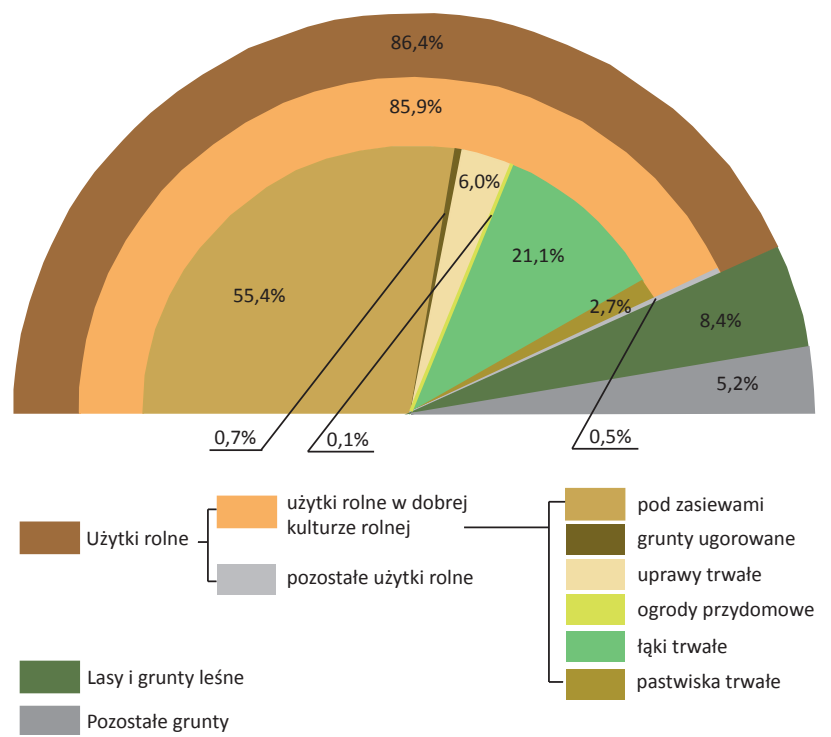

Ryc. 5. Struktura użytkowania gruntów w 2017 r. w województwie mazowieckim Źródło: GUS 2017a

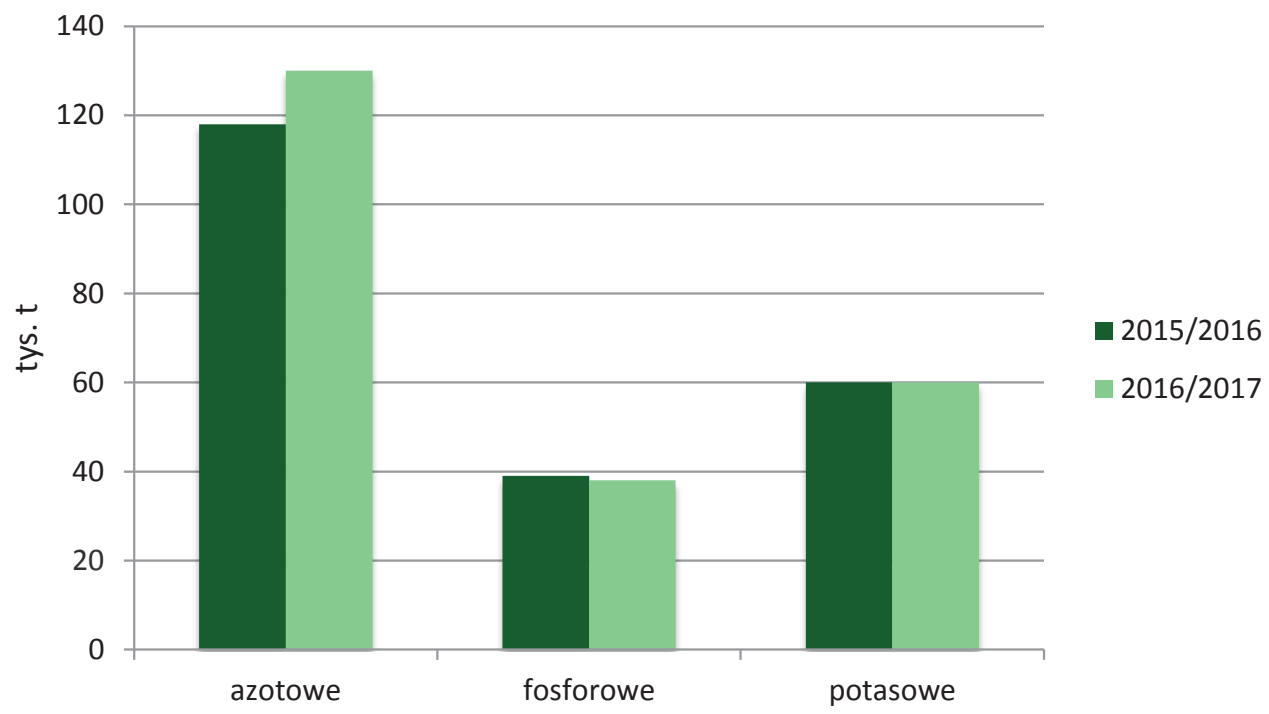

Ryc. 6. Zużycie nawozów mineralnych (NPK)

Źródło: GUS 2017a 


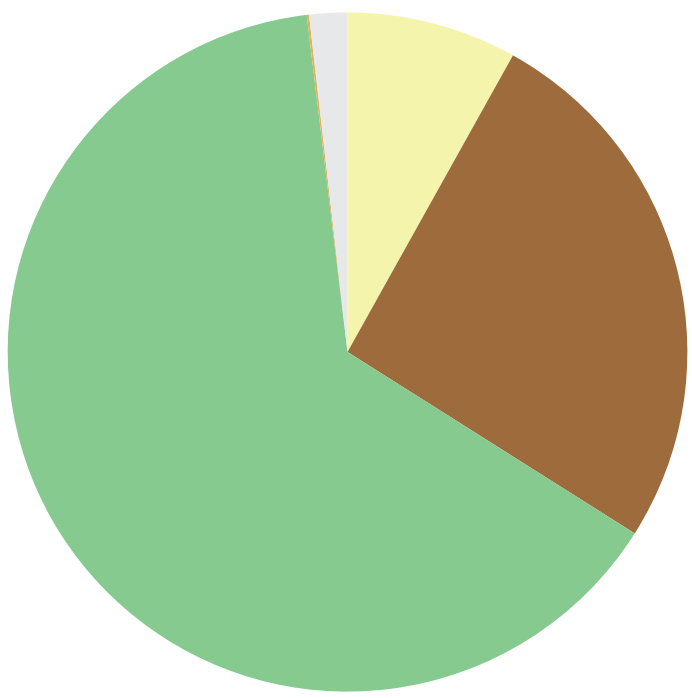

\author{
owadobójcze
}

- grzybobójcze i zaprawy nasienne

chwastobójcze

i hormonalne

gryzoniobójcze

pozostałe

Ryc. 7. Zużycie pestycydów w Polce w 2017 r.

Źródło: opracowanie własne

Niniejsze tendencje przeanalizowano w kontekście ich wpływu na zwierzynę drobna, $\mathrm{w}$ tym ptaki kurowate.

Wzrost powierzchni upraw powoduje lokalizowanie gniazd na niewielkiej ich części. Taka ich lokalizacja przyczynia się do większego narażenia ptaków na ataki drapieżników, które chętnie wykorzystują struktury graniczne z dziką roślinnością jako miejsce polowań i trasy wędrówek. Rozdrobnione uprawy, które jak wykazano powyżej-zanikają - sprzyjają rozmieszczeniu gniazd na całej powierzchni pola, co tym samym chroni je przed atakami z ich strony [Panek 2009].

Stosowanie nawozów azotowych (NPK) pogłębia występujący na glebach kwaśnych, których w Polsce jest $60 \%$, stan niedoboru wapnia i magnezu. Ponadto uproszczenie składu botanicznego roślinności łąkowej, w wyniku rozwoju traw azotolubnych, powoduje zubożenie pokarmu roślinnego w mikroelementy. Zmniejszenie zawartości takich składników jak: wapń, sód, magnez, miedź czy kobalt zaburza prawidłowy wzrost, funkcjonowanie i rozwój zwierzyny drobnej [Majdecka, Kryński 2009].

Stosowanie w coraz większych ilościach pestycydów również nie pozostaje obojętne. Pomimo bowiem używania w przeważającej ilości środków IV i V klasy toksyczności, stwierdzono u piskląt zmniejszoną aktywność ruchową i biegunkę. U ptaków dorosłych zaobserwowano, iż kontakt z pestycydami powoduje skrócenie nośności, co przekłada się na liczbę jaj oraz wskaźnik wylęgu. Z jaj poddanych niewielkiej dawce środków owadobójczych podczas oprysków wylęga się mniej o 10 do $25 \%$ zdrowych piskląt. Powodują one także zmniejszenie bazy pokarmowej m.in. dla młodych ptaków, takich jak bażant czy kuropatwa. 
Postępująca mechanizacja oraz całkowity zanik siły pociągowej przyczynia się nie tylko do niszczenia gniazd, ale także do likwidacji zadrzewień, zakrzewień śródpolnych oraz miedz. Proces ten prowadzi do zaniku miejsc sprzyjających rozmnażaniu roślin i zwierząt oraz znacznego ograniczenia różnorodności gatunkowej agrocenoz [Motyl, Sadkowski 2012] (ryc. 8).

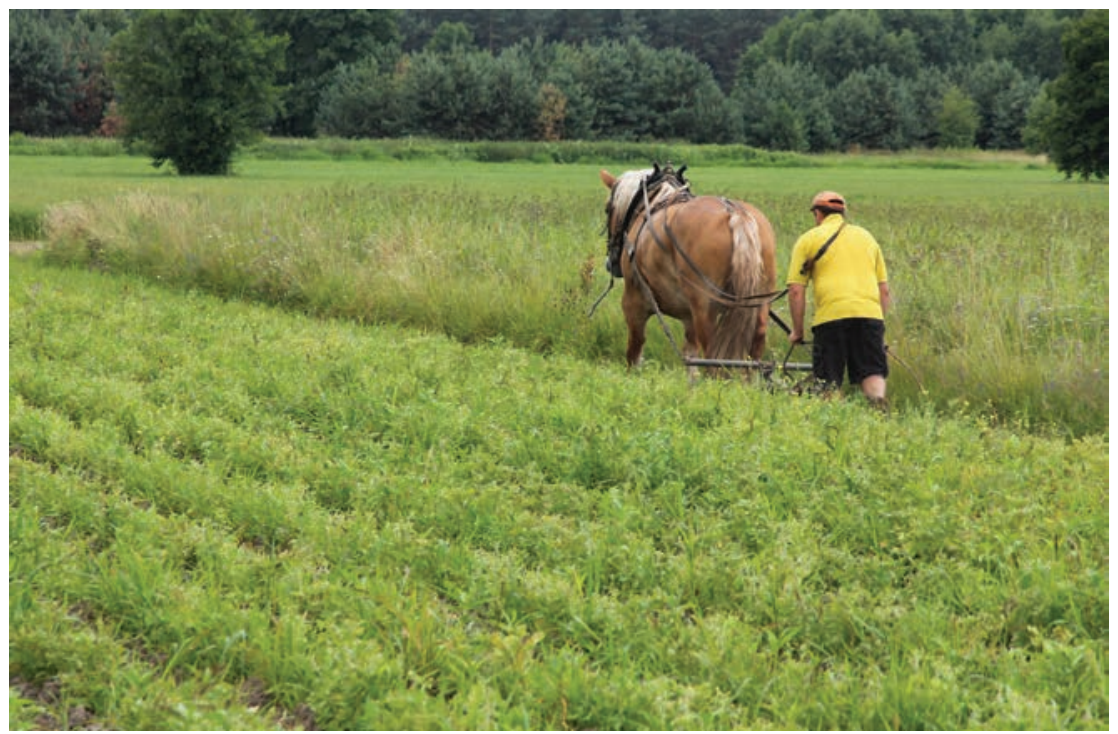

Ryc. 8. Orka konna

Fot. J. Wojtatowicz

\section{Wybrane zmiany w środowisku przyrodniczym krajobrazu rolniczego}

\section{Awifauna}

Ptaki polskiego krajobrazu rolniczego uznawane są za najbardziej zagrożoną grupę. Powyższe potwierdzają ich tendencje spadkowe na przestrzeni lat 2000-2016 wg wskaźnika $\mathrm{FBI}^{14}$.

W tym okresie wartość jego spadła o 13\% przy średnim, rocznym tempie spadku wynoszącym 0,6\%. Istotne spadki zanotowano w przypadku 11 gatunków, co stanowi 50\% grupy

\footnotetext{
${ }^{14}$ Wskaźnik FBI (Farmland Bird Index) - oficjalnie stosowany wskaźnik w krajach Unii Europejskiej, składają się na niego wskaźniki liczebności 22 gatunków ptaków ściśle powiązanych z terenami użytkowanymi rolniczo, tj: bocian biały, cierniówka, czajka, dudek, dymówka, dzierlatka, gąsiorek, kląskawka, kulczyk, makolągwa, mazurek, ortolan, pliszka żółta, pokląskwa, potrzeszcz, pustułka, rycyk, skowronek, szpak, świergotek łąkowy, trznadel, turkawka [wikipedia.pl].
} 
badanej ${ }^{15}$, wzrosty w przypadku 8 gatunków $-36 \%{ }^{16}$. Sytuację stabilną wykazały tylko 2 gatunki ${ }^{17}$. Na obszarach Specjalnej Ochrony Ptaków Natura 2000 wskaźnik ten był stabilny [Motyl, Sadkowski 2012, s. 65-78].

Porównując powyższe wyniki z sytuacją w Europie zwraca uwagę, występujący podobnie jak w Polsce, trend spadkowy populacji ptaków związanych z krajobrazem rolniczym. Od 2000 r. zanotowano obniżenie wskaźnika o 10\%, a od 1980 o 60\% [https://pecbms.info/] (ryc. 9).

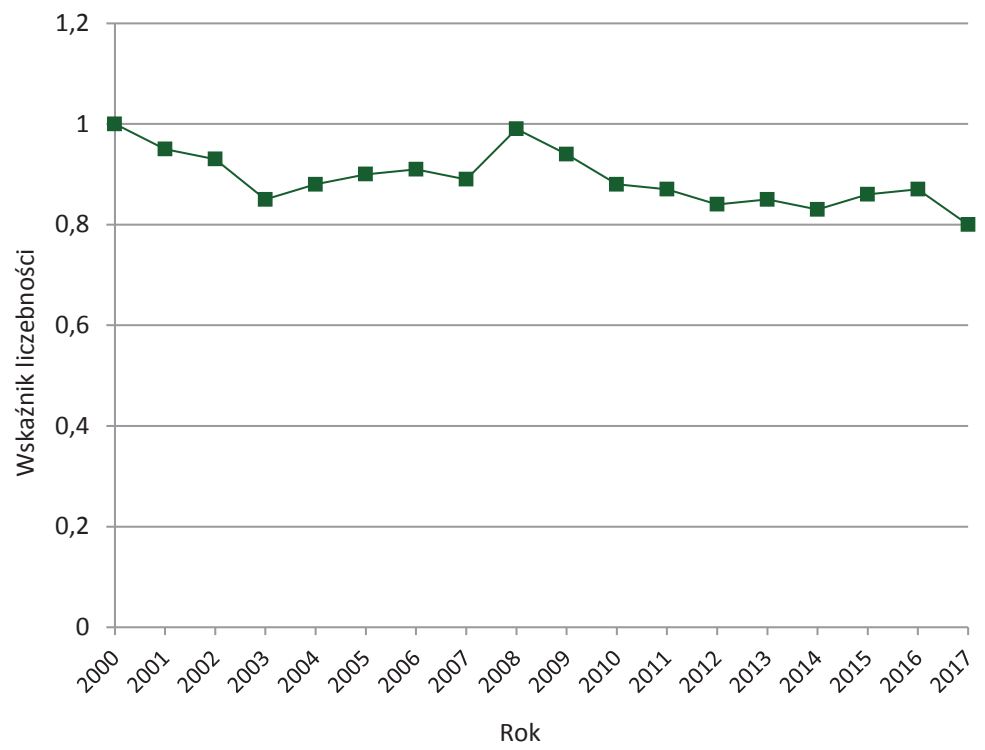

Ryc. 9. Stan populacji ptaków wg wskaźnika FBI

Źródło: monitoringptakow.gios.gov.pl

Na przedstawione zmiany wpływa intensyfikacja rolnictwa. Potwierdzają to spadki liczebności gatunków ptaków związanych z ekstensywnym gospodarowaniem jak trznadel, ortolan, makolągwa czy kuropatwa [Chylarecki 2010, s. 1-10].

\footnotetext{
${ }^{15}$ Trznadel, turkawka, świergotek łąkowy, skowronek, rycyk, cierniówka, czajka, makolągwa, ortolan, pliszka żółta, pokląskwa

${ }^{16}$ Dudek, gąsiorek, kląskawka, szpak, kulczyk, mazurek, potrzeszcz, pustułka

${ }^{17}$ Bocian biały, dymówka
} 


\section{Ptaki kurowate}

Tendencje spadkowe wykazują wszystkie z omawianych gatunków ptaków kurowatych. Ze względu na charakter czasopisma tendencje te ograniczono do 1 gatunku - kuropatwy. Drastyczne spadki jej populacji mają miejsce zarówno w Europie ${ }^{18}$, jak i w Polsce. Dowodzą tego prowadzone w tym zakresie badania monitoringowe na terenie Polski. W latach 70. liczebność tego ptaka szacowano na 7 mln sztuk, w latach 90 . już tylko na 0,5 mln. W latach 2001-2010 wiosenne zagęszczenie kuropatw wynosiło od mniej niż 1 do 10 par na km². Powyższe tendencje potwierdziły kolejne badania przeprowadzone w latach 2015-2017 [Chylarecki i in. 2018].

Podobny trend stwierdzono także w województwie mazowieckim, w którym w latach 1992-1998 regres wyniósł 70\% [monitoringptakow.gios.gov.pl], co ilustruje rycina 10.

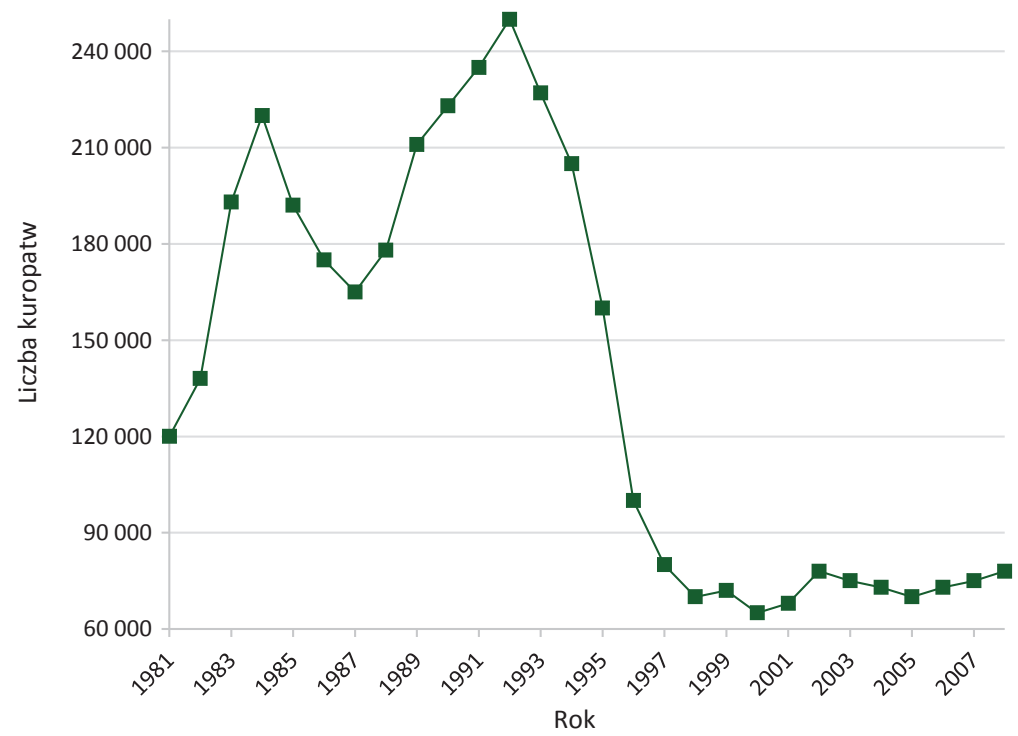

Ryc. 10. Stan populacji kuropatw na terenie obecnego województwa mazowieckiego w latach 1981-2008

Źródło: Motyl, Sadkowski 2012, s. 65-78

Na uwagę zasługuje ponadto fakt obniżenia liczebności tego gatunku również na terenie Kampinoskiego Parku Narodowego, w którym liczebność par lęgowych w latach 2001-2008 oszacowano na około 5 [Michalska-Hejduk, Bomanowska 2009].

\footnotetext{
${ }^{18}$ Zgodnie z Międzynarodową Czerwoną Księgą IUCN kuropatwa należy do gatunków, które zmniejszają swoją liczebność [https://www.iucnredlist.org/species/22678911/85929015].
} 


\section{Wyniki}

\section{Podział pokarmu roślinnego na kategorie}

Rośliny krajobrazowe (Rk). Do grupy tej przydzielono m.in. rośliny uprawne i ozdobne. W przypadku roślin uprawnych zauważyć należy, że znaczna powierzchnia monokulturowych roślin uprawnych w sposób dominujący wpływa na walory krajobrazowe. Rośliny te $\mathrm{w}$ masie mogą być odbierane nie tylko jako zgodne z panującymi poglądami estetycznymi, ale i przytłaczające. Jako przykład może posłużyć bezkresny łan kwitnącego rzepaku, który w ujęciu kompozycyjnym integruje się ze współczesnymi poglądami minimalizmu. Innym tego przykładem może być łan kukurydzy, który przerastając ponad linię horyzontu wzroku człowieka jest w odbiorze monotonny i nijaki. Do kategorii tej zaliczono także rośliny o walorach ozdobnych. Rosną one zwykle w rozproszeniu lub niewielkich skupieniach wśród innych roślin stanowiących dla nich tło. $W$ ich przypadku walory krajobrazowe wynikają z poglądów estetycznych nakierowanych na wartości kulturowo-historyczne, romantycznosentymentalne czy ochrony przyrody, włączając się do tzw. nurtu ekologicznego.

Rośliny zagrożone na Mazowszu (RzM), rośliny zagrożone (Rz). Analiza literatury wskazuje, że liczba roślin zagrożonych na Mazowszu nie zawsze pokrywa się z liczbą roślin zagrożonych w Polsce. Wiele bowiem gatunków, takich jak np. kurzyślad polny Anagallis arvensis L., Inicznik drobnoowocowy Camelina microcarpa Andrz. ex DC., chaber bławatek Centaurea cyanus L. ustępuje jedynie w tym województwie.

Chwasty (Ch). Postępująca antropopresja przyczynia się w coraz większym stopniu do ich zaniku. W Polsce 60\% roślin związanych z uprawami, które przybyły na przełomie XV i XVI w. uważa się za zagrożone wyginięciem [Feledyn-Szewczyk 2013, s. 18]. Przyczyną zaistniałej sytuacji jest intensyfikacja rolnictwa, a w szczególności: wielkopowierzchniowe uprawy, zwalczanie chemiczne, zmiany terminów siewów, wprowadzanie nowych technik zbioru, oczyszczanie materiału siewnego czy ograniczenie stosowania płodozmianu. Ponadto wzrost udziału upraw ozimych w stosunku do jarych spowodował 25\% spadek liczby gatunków chwastów tam występujących [Inglot 1986; Feledyn-Szewczyk 2012, s. 63-72; Feledyn-Szewczyk 2013, s. 18; Bomanowska, Michalska-Hejduk 2008, s. 5-11].

Za najsilniej zagrożone uważa się chwasty związane z tradycyjnymi uprawami np. lnu jak: lnicznik właściwy, kanianka lnowa, życica lnowa czy sporek polny. Niską liczebnością chwastów cechują się także pola uprawne terenów chronionych (ryc. 11). W Kampinoskim Parku Narodowym na polach stwierdzono, że prawie połowa, tj. 148 gatunków występowała bardzo rzadko i rzadko (na 1-2 stanowiskach) [Bomanowska, Michalska-Hejduk 2008, s. 5-11]. Chwasty i żerujące w nich owady spełniają rolę bazy pokarmowej dla wielu gatunków. Wpływają ponadto na zwiększenie mikroflory i mikrofauny glebowej, działają antagonistycznie w stosunku do patogenów roślin uprawnych np. komosa biała - mszyca burakowa [Feledyn-Szewczyk 2013, s. 16-17]. 


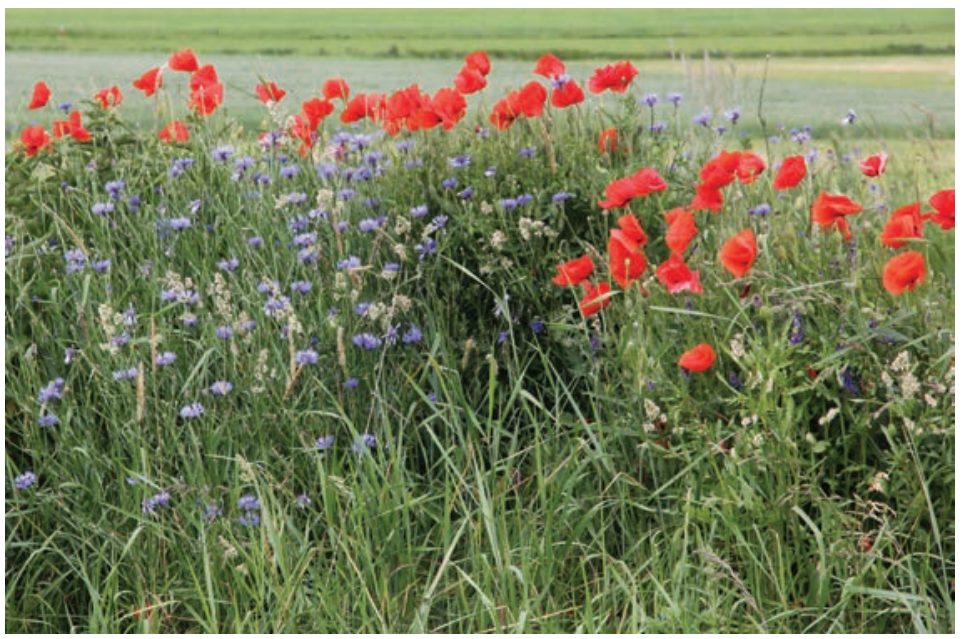

Ryc. 11. Ginące na Mazowszu chabry i maki stanowiące pokarm kuropatwy

Fot. J. Wojtatowicz

Rośliny upraw rolniczych (Rur). Analiza lat 1990-2018 wskazuje na zmiany w strukturze zasiewów. Prowadzą one do systematycznego powiększania powierzchni upraw kukurydzy, rzepaku i rzepiku (ryc. 12). W 1990 r. kukurydza zajmowała 59 tys. ha, w 2000 - 318,7 tys. ha, a w 2018 - 645 tys. ha. Podobnie, w przypadku rzepaku i rzepiku, których areał w tym okresie zwiększył się o 344,7 tys. hektarów wynosząc ostatecznie 845,1 tys. ha.

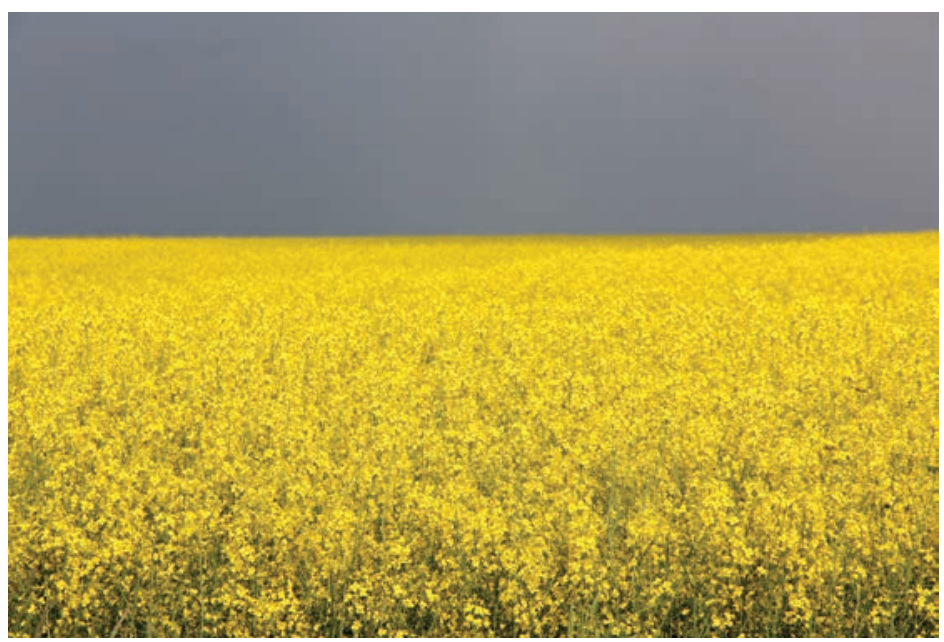

Ryc. 12. Łan rzepaku

Fot. J. Wojtatowicz 
Zmiany te charakterystyczne są także dla Mazowsza. Potwierdza to porównanie lat 2016 i 2017. Powierzchnia upraw kukurydzy wzrosła o 19,9\%, a rzepaku i rzepiku o 41,2\%. Przedstawione zmiany odbywają się kosztem takich roślin uprawnych jak proso czy gryka.

Zmniejszeniu uległa także powierzchnia roślin pastewnych, w tym strączkowych i motylkowych. W 1990 r. zajmowały one w Polsce 2342,2 tys. ha, a w 2018 ponad połowę mniej, tj. 1014,3 tys. ha. Na Mazowszu spadek ten, na przestrzeni 2016 i 2017 r., wyniósł 59\% [GUS 2018a; GUS 2017b].

Podobna tendencja występuje także w odniesieniu do warzyw, które obecnie stanowią 1,5\% powierzchni otwartej zasiewów w Polsce [GUS 2018a; GUS 2017b].

Przedstawione zmiany przyczyniają się do zmniejszania miejsc pozbawionych roślinności w międzyrzędziach. Przekłada się to na spadek dostępnej bazy pokarmowej, dogodnych miejsc do jej zbierania, kąpieli i wypoczynku.

\section{Zestawienie danych liczbowych}

Wyniki przedstawiające liczbę roślin przydzielonych do poszczególnych kategorii, a także ich udział procentowy w całej bazie pokarmowej zestawiono w tabeli 1 .

Tabela 1. Liczba roślin i ich udział procentowy w podziale na kategorie, w odniesieniu do całej bazy pokarmowej badanych ptaków

\begin{tabular}{|l|r|r|r|}
\hline \multicolumn{1}{|c|}{ Kategoria } & Przepiórka & Kuropatwa & Bażant \\
\hline Rośliny krajobrazowe & 14 & 49 & 103 \\
& $25 \%$ & $55 \%$ & $49,7 \%$ \\
\hline Rośliny ozdobne & 12 & 35 & 87 \\
\hline Rośliny zagrożone na & $21 \%$ & $39,3 \%$ & $42 \%$ \\
Mazowszu & 18 & 13 & 31 \\
\hline Rośliny zagrożone & $32 \%$ & $14,6 \%$ & $14,9 \%$ \\
\hline \multirow{2}{*}{ Chwasty } & 11 & 6 & 12 \\
& $20 \%$ & $6,7 \%$ & $5,7 \%$ \\
Rośliny upraw rolniczych & 31 & 34 & 61 \\
& $56,3 \%$ & $38,2 \%$ & $29,4 \%$ \\
Rośliny użytkowe & 10 & 21 & 30 \\
& $18,1 \%$ & $23,5 \%$ & $14,4 \%$ \\
\hline
\end{tabular}

Źródło: opracowanie własne 
Omawiane kuraki żywią się w sumie 351 roślinami (tabela 2 - Aneks). Siedemnastoma gatunkami roślin odżywiają się trzy badane gatunki ptaków. Należą do nich: szarłat szorstki Amaranthus retroflexus L., kurzyślad polny Anagallis arvensis L., owies zwyczajny Avena sativa L., chaber bławatek Centaurea cyanus L., komosa biała Chenopodium album L., chwastnica jednostronna Echinochloa crus-galli (L.) P.Beauv., jęczmień zwyczajny Hordeum vulgare L., poziewnik szorstki Galeopsis tetrahit L., życica roczna Lolium temulentum L., nostrzyk biały Melilotus albus Medik., mak polny Papaver rhoeas L., żyto zwyczajne Secale cereale L., sporek polny Spergula arvensis L., włośnica zielona Setaria viridis (L.) P.Beauv., gwiazdnica pospolita Stellaria media L. Vill, mniszek lekarski Taraxacum officinale Webb, pszenica zwyczajna Triticum vulgare Vill. Ponad pięćdziesięcioma gatunkami roślin odżywiają się dwa gatunki ptaków.

W podziale na kategorie największą bazę żerową dla kuropatwy i bażanta stanowią rośliny krajobrazowe (55\%, 49,7\%), użytkowe $(50,5 \%, 57,4 \%)$ i ozdobne $(39,3 \%$, 42\%). Dla przepiórki zaś chwasty (56,3\%), rośliny użytkowe (41,8\%) i zagrożone na Mazowszu (32\%). Chwasty w przypadku kuropatwy i bażanta również stanowią znaczący procent pokarmu, wynosząc kolejno 38,2\% i 29,4\%, a rośliny zagrożone ponad 14\% wszystkich zjadanych roślin.

Rośliny upraw rolniczych stanowiły 23,5\% w przypadku kuropatwy, przepiórki 18,1\%, a bażanta $14,4 \%$ ich bazy żerowej.

Analiza uzyskanych wyników wskazuje, że przedstawiona liczba gatunków jest zaniżona. Zgodnie bowiem z przyjętą metodą nie traktowano podanego w literaturze rodzaju jako gatunku. Przykładami takimi są słonecznik zwyczajny (bażant), słonecznik (kuropatwa, przepiórka), len zwyczajny (bażant), len (kuropatwa), proso (bażant) proso zwyczajne (kuropatwa, przepiórka), kukurydza zwyczajna (bażant), kukurydza (kuropatwa, przepiórka).

\section{Proponowane rozwiązania}

W świetle przedstawionych zmian w krajobrazie rolniczym i ich wpływu na faunę, szczególnie ważne staje się uwzględnianie przyrodniczych wartości tych terenów. Aspekt ten powinien być brany pod uwagę zarówno w procesie planowania, jak i gospodarowania. W działaniach tych powinny być zatem uwzględnione nie tylko obszary chronione, ale i pozostałe, które pełnią w tym zakresie istotną rolę [Kupidura, Łuczewski, Kupidura 2011; Żarska 2006].

Wśród zasad koniecznych do zachowania różnorodności biologicznej w gminach wymienia się m.in. potrzebę zgodności sposobu kształtowania i użytkowania z warunkami przyrodniczymi, a także projektowanie systemów przyrodniczych. Zgodnie z tymi założeniami $\mathrm{w}$ wielu publikacjach naukowych proponowane są modele ekologiczno-przestrzenne służące kształtowaniu gmin. Zaproponowano, m.in. dla gminy Chotcza położonej w województwie mazowieckim, koncepcję kratownicy, określoną jako 3 razy m. Polega ona na maksymalizacji liczby ostoi przyrodniczych, korytarzy ekologicznych i ich hierarchiczności [Żarska 2006]. 
Analizy zaproponowanych rozwiązań i literatury faunistycznej wskazują na konieczność pełnego rozpoznania terenu. Działania takie powinny odbywać się pod kątem występujących gatunków roślin i zwierząt i możliwości ich zachowania na danym obszarze. Uzasadniają to często występujące w tym zakresie różnice, które niejednokrotnie wzajemnie się wykluczają. Rozważne działania w planowaniu i gospodarowaniu przestrzenią wymagają ustalenia możliwości i hierarchii ochrony. Ich świadoma realizacja służyć może zarówno gatunkom rzadkim, jak i typowym dla krajobrazu rolniczego.

Doświadczenia autorów wskazują że wymienione problemy na etapie prac projektowych, urządzania i pielęgnacji powinny być rozwiązywane także przez architektów krajobrazu. Na uwagę w tych rozważaniach zwraca fakt, że obszary wiejskie chroniące bioróżnorodność, będą także atrakcyjne pod względem turystyki i wypoczynku. Zachowana mozaika tych terenów z zadrzewieniami śródpolnymi, zakrzewieniami i chwastami stanowić może miejsce migracji i schronień. Daje także możliwość obserwacji przyrody i świadczy o cennej swojskości tych krajobrazów.

Zachowanie tych wartości, które w krajach Europy zachodniej coraz częściej należą do rzadkości oraz promocja agroturystyki, mogą być ważnym elementem służącym rozwojowi obszarów wiejskich.

Rozważania odnoszące się do kształtowania krajobrazu poprowadzono w kontekście wybranych ptaków kurowatych. W przypadku omawianych gatunków, kwestiami które znacząco wpływają na ich liczebność są: miejsca gniazdowania, zdobywania pokarmu i schronień przed drapieżnikami, głównie lisem. Poprowadzone badania wykazały, że ptaki te w przypadku upraw wielkopowierzchniowych gniazdują na ich niewielkim obszarze. Częściej są one tym samym narażone na ataki drapieżników. Uzasadnia to fakt, że tereny graniczne z dziką roślinnością wykorzystywane są przez nie jako miejsce polowań i trasę wędrówek. Ważne zatem staje się zapewnienie im odpowiednich schronień w postaci na przykład remiz. Wykazano ponadto, że zniesienia w zbożach rzadziej padały łupem drapieżników niż w roślinności dzikiej. Podobny wynik uzyskano w przypadku rozdrobnionych pól [Panek 2009, s. 13-22; Fruziński 1981, s. 142-143].

Uznać zatem należy, że modele przestrzenno-krajobrazowe w przypadku omawianych gatunków uwzględniać powinny pasmowy układ podstref. Układ ten powinien znajdować się na pograniczu różnych zbiorowisk z gruntami ornymi i użytkami trwałymi. W modelach takich powinno się uwzględniać strefy składające się z licznych podstref o zróżnicowanej strukturze wysokościowej np. obrzeża lasów, wysokie kępy zadrzewień przywodnych i śródpolnych. Podstrefy o funkcji wydzielającej powinny także występować na obszarach, gdzie obecnych jest wiele drobnych zbiorowisk. Przykładami takimi mogą być tereny wzdłuż dróg polnych, szczególnie tych o nawierzchni utwardzonej, rowów, skarp, miedz, skupin krzewów, zarośli, wzniesień, zagłębień suchych lub wypełnionych woda, stert kamieni. Szczególne istotne w przypadku omawianych gatunków są także obecne i potencjalne miejsca schronień, gniazdowania, kąpieli, grzebania w piasku i inne, gdzie zdobywają pokarm. Za wartościowe w tym zakresie uznać należy zbiorowiska położone w strefie cienia, zasięgu korzeni, niższych plonów, których obecność nie wpłynie znacząco na wyniki 
produkcji, a przyczyni się do zachowania bioróżnorodności i bezpieczeństwa agroturystów [Bartman 1974, s. 56-75; Młynkowiak, Kutyna 2010, s. 043-074].

Cenne będą też pasy, np. 6-metrowe wokół pól, pozbawione oprysków. W Anglii ich zachowanie znacząco wpłynęło na liczebność ptaków z rodziny kurowatych [Panek 2009, s. 13-22].

Za pilną potrzebę uznać należy utworzenie nowych kategorii obszarów umożliwiających rozwój gatunków roślin stanowiących pokarm dla omawianych gatunków. Konieczne w tych pracach jest współdziałanie specjalistów z różnych dziedzin. Zespoły planistów i projektantów, wspomagane wiedzą fachowców, powinny rozwiązywać problemy ochrony ptaków, kompleksowo w ramach zintegrowanych planów i projektów. Skala tych opracowań powinna być adekwatna do stawianych zadań. Powyższe jest niezmiernie istotne z punktu widzenia ochrony przyrody, rodzimego krajobrazu i rozwoju agroturystyki.

\section{Literatura}

Bartman E., 1974, Wykorzystanie lasów do celów rekreacyjnych, Rozprawy Naukowe, 33, Dział Wydawnictw, Warszawa, s. 56-75.

Bogdanowicz W., Chudzicka E., Pilipiuk J., Skibińska E., 2014, Fauna Polski: charakterystyka i wykaz gatunków. T. 4, Strunowce (Chordata), kręgowce (Vertebrata): kręgowce bezszczękowe (Petromyzontidae), promieniopłetwe (Actinopterygii), ptazy (Amphibia), gady (Reptilia), ptaki (Aves), ssaki (Mammalia) = Fauna of Poland: characteristics and checklist of species, 4, Muzeum i Instytut Zoologii PAN, Warszawa.

Bogdanowski J., 1999, Diagnoza i prognoza architektury krajobrazu wsi polskiej a parkowy krajobraz jutra [w:] J. Kurek (red.), Wieś Polska współczesne przemiany i rozwój, Materiały Ogólnopolskiej Konferencji Naukowej Kraków 20-21 maja 1999, Pro-Art., Kraków, s. 25-31.

Bomanowska A., 1998, Niektóre rzadkie i zagrożone gatunki roślin segetalnych w Kampinoskim Parku Narodowym, Acta Universitatis Lodziensis Folia Botanica, 13, s. 107-112.

Bomanowska A., Michalska-Hejduk D., 2008, Czynna ochrona warunkiem zachowania cennych gatunków związanych z tradycyjnym rolnictwem w Kampinoskim Parku Narodowym, Materiały konferencyjne Konferencji popularno-naukowej Ligi Ochrony Przyrody, LOP, s. 5-11.

Chylarecki P., 2010, Ptaki jako wskaźnik różnorodności biologicznej: analiza zagrożeń bioróżnorodności, Ochrona różnorodności biologicznej w Polsce, Posiedzenie Komisji Ochrony Środowiska, Zasobów Naturalnych i Leśnictwa, Warszawa 20 maja 2010 r., s. 1-10.

Chylarecki P., Chodkiewicz T., Neubauer G., Sikora A., Meissner W., Woźniak B., Wylegała P., Ławicki Ł., Marchowski D., Betleja J., Bzoma S., Cenian Z., Górski A., Korniluk M., Moczarska J., Ochocińska D., Rubacha S., Wieloch M., Zielińska M., Zieliński P., Kuczyński L., 2018, Trendy liczebności ptaków w Polsce, Główny Inspektorat Ochrony Środowiska, Warszawa. 
Feledyn-Szewczyk B., 2012, Ocena różnorodności zbiorowisk segetalnych w roślinach uprawianych w wybranych gospodarstwach ekologicznych w województwie lubelskim, Journal of research and apllications in agricultural engineering, 57, 3, s. 63-72.

Feledyn-Szewczyk B., 2013, Wpływ sposobu użytkowania gruntów na różnorodność gatunkowa flory segetalnej, Monografe i rozprawy naukowe, 36, IUNiG, Puławy, s. 16-18.

Fruziński, B., 1981, Ekologiczne podstawy gospodarstwa łowieckiego, Skrypty Akademii Rolniczej w Poznaniu, AR, Poznań, s. 142-143.

Inglot S., 1986, Z dziejów wsi polskiej i rolnictwa, Ludowa Spółdzielnia Wydawnicza, Warszawa. Jakubowska-Gabara J., Kucharski J., 1999, Ginace i zagrożone gatunki flory naczyniowej zbiorowisk naturalnych i pótnaturalnych Polski środkowej, Fragmenta floristica et geobotanica. Series polonica, A.VI, s. 55-74.

Krause J., Lisiecka A., Szczepaniak S., 2004, Ozdobne rośliny jednoroczne i dwuletnie, AR w Poznaniu, Poznań.

Kupidura A., Łuczewski M., Kupidura P., 2011, Wartość krajobrazu. Rozwój przestrzeni obszarów wiejskich, Wydawnictwo Naukowe PWN, Warszawa.

Majdecka T., Kryński E., 2009, Chemizacja produkcji roślinnej i życia codziennego, a zdrowie zwierzyny, Nauka Łowiectwu. Środowiskowe uwarunkowania kryzysu zwierzyny drobnej cz. 4, Mazowsze, Serce Polski, Samorząd Województwa Mazowieckiego, 13.

Marks M., Markowski M., 2012, Postęp w produkcji roślinnej i jego wpływ na krajobraz rolniczy, Acta Scientarium Polonorum. Administratio Locorum, 11, 2, s. 145-154.

Michalska-Hejduk D., Bomanowska A., 2009, Rola Kampinoskiego Parku Narodowego w zachowaniu różnorodności biologicznej i krajobrazowej dawnych obszarów wiejskich, Kampinoski Park Narodowy: Agencja Reklamowo-Wydawnicza Arkadiusz Grzegorczyk, Łódź-Izabelin.

Mirek Z., Zarzycki K., 2006, Red lists of plants and fungi in Poland. Czerwona lista roślin i grzybów Polski, W. Szafer Institute of Botany, Polish Academy of Sciences, Kraków.

Młynkowiak E., Kutyna I., 2010, Zbiorowiska leśne w obrębie śródpolnych zadrzewieńw zachodniej części Pojezierza Drawskiego, Badania Fizjograficzne Seria B Botanika, I, Poznań, s. 043-074.

Motyl T., Sadkowski T., 2012, Program odbudowy populacji zwierzyny drobnej w województwie mazowieckim, cz. 7, Narodowy Fundusz Ochrony Środowiska i Gospodarki Wodnej, Warszawa, s. $65-77$.

Panek M., 2009, Intensywność rolnictwa, a liczebność kuropatw, Nauka Łowiectwu. Środowiskowe uwarunkowania kryzysu zwierzyny drobnej, cz. 4, Samorząd Województwa Mazowieckiego, Warszawa, s. 13-22.

Pinowski J.K., 2018, Z ptakami przez życie. Autobiografia ornitologa-ekologa, Muzeum i Instytut Zoologii PAN, Warszawa. 
Podbielkowski Z., 1985, Słownik roślin użytkowych, Państwowe Wydawnictwo Rolnicze i Leśne, Warszawa.

Seneta W., Dolatowski J., 2009. Dendrologia, Wydawnictwo Naukowe PWN, Warszawa.

Słojewski R., 1976, Obszary wiejskie w planowaniu przestrzennym zagadnienia metodyczne $i$ instruktażowe, Biuro Studiów i Projektów Rozwoju Przestrzennego Województwa w Szczecinie: Ministerstwo Gospodarki Przestrzennej i Budownictwa. Departament Urbanistyki i Architektury, Szczecin.

Ulbrych A., 2009, Bioróżnorodność szansa rozwoju obszarów wiejskich, Polskie krajobrazy wiejskie dawne i wspótczesne, Prace Komisji Krajobrazu Kulturowego, 12, Sosnowiec, s. 265-271.

Warcholińska A. U.,1987, Lista zagrożonych gatunków roślin segetalnych środkowej Polski - A list of endangered segetal plant species in central Poland, Fragmenta Floristica et Geobotanica, XXXI-XXXII,1-2, s. 225-231.

Warcholińska A.U.,1998, Stan i rozmieszczenie niektórych chwastów polnych w środkowej Polsce, Acta Universitatis Lodziensis Folia Botanica, 12, s. 115-130.

Wuczyński A., Kujawa K., Dajdok Z., Grzesiak W., 2011, Species richness and composition of bird communities in various field margins of Poland, Agriculture, Ecosystems and Environment, 141, s. 202-209.

Żarska B., 2006, Modele ekologiczno-przestrzenne i zasady kształtowania krajobrazu gmin wiejskich, Wydawnictwo SGGW, Warszawa.

Rocznik statystyczny rolnictwa. Roczniki Branżowe, 2001, GUS, Warszawa.

Rocznik statystyczny rolnictwa, 2018, GUS, Warszawa.

Rolnictwo w 2017 Analizy statystyczne, 2017, GUS, Warszawa.

Rolnictwo w województwie mazowieckim w 2017 roku, 2017a, GUS, Warszawa.

Rolnictwo w 1998 na tle lat poprzednich, 1998, GUS, Warszawa.

System gospodarowania przestrzenia gminy jako dobrem publicznym, 2016, NIK, Warszawa.

Użytkowanie gruntów i powierzchnia zasiewów w 2018, 2018b, GUS, Warszawa.

\section{Strony internetowe}

https://komisjafaunistyczna.pl/

https://www.iucnredlist.org/species/22678911/85929015

https://komisjafaunistyczna.pl/ 
https://monitoringptakow.gios.gov.pl

https://www.nik.gov.pl/aktualnosci/nik-o-systemie-gospodarowania-przestrzenia-gmin. html

https://pecbms.info/

http://www.theplantlist.org/

https://wikipedia.pl

[wszystkie strony internetowe dostępne w listopadzie 2020] 


\section{Aneks}

Tabela 2. Zestawienie pokarmu roślinnego przepiórki, kuropatwy i bażanta

\begin{tabular}{|c|c|c|c|}
\hline Nazwa łacińska & Nazwa polska & Kategoria & Źródło \\
\hline \multicolumn{4}{|c|}{ Coturnix coturnix L., przepiórka } \\
\hline Achillea L. & krwawnik & & $\begin{array}{r}\text { Jabłoński, Gorazdowski } \\
2004: 32\end{array}$ \\
\hline Adonis aestivalis L. & miłek letni & $\begin{array}{l}(\mathrm{RzM}),(\mathrm{Rz}) \\
(\mathrm{Ro}),(\mathrm{Ch})\end{array}$ & Glutz 1973: 318 \\
\hline Adonis flammea Jacq. & miłek szkarłatny & $\begin{array}{l}(\mathrm{RzM}),(\mathrm{Rz}) \\
(\mathrm{Ch})\end{array}$ & Glutz 1973: 318 \\
\hline $\begin{array}{l}\text { Ajuga chamaepitys (L.) } \\
\text { Schreb. }\end{array}$ & $\begin{array}{l}\text { dąbrówka } \\
\text { żółtokwiatowa }\end{array}$ & (RzM), (Rz) & Glutz 1973: 318 \\
\hline $\begin{array}{l}\text { Amaranthus retroflexus } \\
\text { L. }\end{array}$ & szarłat szorstki & $(\mathrm{Ch}),(\mathrm{Ru})$ & Glutz 1973: 318 \\
\hline Anagallis arvensis L. & kurzyślad polny & $\begin{array}{l}(\mathrm{RzM}),(\mathrm{Ch}), \\
(\mathrm{Ru})\end{array}$ & Glutz 1973: 318 \\
\hline $\begin{array}{l}\text { Anagallis arvensis } \\
\text { subsp. foemina (Mill.) } \\
\text { Schinz \& Thell. }\end{array}$ & $\begin{array}{l}\text { kurzyślad } \\
\text { błękitny }\end{array}$ & $(\mathrm{Rz}),(\mathrm{Ch})$ & Glutz 1973: 318 \\
\hline Anethum L. & koper & & $\begin{array}{r}\text { Zcz; Jabłoński, Gorazdowski } \\
2004: 32\end{array}$ \\
\hline Avena L. & owies & & $\begin{array}{r}\text { Cramp 1980: 500, N; Okarma } \\
2008: 80\end{array}$ \\
\hline Avena sativa L. & owies zwyczajny & $\begin{array}{l}\text { (Rk), (Ro), } \\
\text { (Rur) }\end{array}$ & Glutz 1973: 318 \\
\hline Ballota L. & mierznica & & Cramp 1980: 500 \\
\hline Ballota nigra L. & mierznica czarna & $(\mathrm{Ch}),(\mathrm{Ru})$ & N; Cramp1980: 500 \\
\hline Brassica L. & kapusta & & Cramp 1980: 500 \\
\hline $\begin{array}{l}\text { Brassica rapa L. subsp. } \\
\text { rapa }\end{array}$ & kapusta właściwa & (Rur) & Dzięciołowski 1961: 14 \\
\hline Bromus L. & stokłosa & & $\begin{array}{r}\text { Glutz 1973: 317, Cramp 1980: } \\
500\end{array}$ \\
\hline $\begin{array}{l}\text { Camelina microcarpa } \\
\text { Andrz. ex DC. }\end{array}$ & $\begin{array}{l}\text { lnicznik } \\
\text { drobnoowocowy }\end{array}$ & $\begin{array}{l}(\mathrm{RzM}),(\mathrm{Rz}) \\
(\mathrm{Ch})\end{array}$ & Glutz 1973: 318 \\
\hline Cannabis L. & konopia & & Cramp 1980: 500 \\
\hline Cannabis sativa L. & konopia siewna & (Ch), (Rur) & Glutz 1973: 318 \\
\hline
\end{tabular}




\begin{tabular}{|c|c|c|c|}
\hline Nazwa łacińska & Nazwa polska & Kategoria & Źródło \\
\hline Carum L. & kminek & & Dzięciołowski 1961: 14 \\
\hline Centaurea cyanus L. & chaber bławatek & $\begin{array}{l}(\mathrm{RzM}),(\mathrm{Rk}) \\
(\mathrm{Ro}),(\mathrm{Ch}),(\mathrm{Ru})\end{array}$ & Glutz 1973: 318 \\
\hline Cerastium L. & rogownica & & $\begin{array}{r}\text { Glutz 1973: 317, Cramp 1980: } \\
500\end{array}$ \\
\hline Chenopodium L. & komosa & & Cramp 1980: 500 \\
\hline Chenopodium album $\mathrm{L}$. & komosa biała & $(\mathrm{Rk}),(\mathrm{Ch}),(\mathrm{Ru})$ & $\begin{array}{r}\text { Glutz 1973: 318, N; Cramp } \\
1980: 500\end{array}$ \\
\hline $\begin{array}{l}\text { Cirsium arvense (L.) } \\
\text { Scop. }\end{array}$ & ostrożeń polny & (Ch) & Glutz 1973: 318 \\
\hline $\begin{array}{l}\text { Cladium mariscus (L.) } \\
\text { Pohl }\end{array}$ & kłoć wiechowata & $(\mathrm{Rz})$ & Glutz 1973: 318 \\
\hline Consolida regalis Gray & ostróżeczka polna & $\begin{array}{l}(\mathrm{RzM}),(\mathrm{Rz}) \\
(\mathrm{Ro})\end{array}$ & Glutz 1973: 318 \\
\hline Cucumis L. & ogórek & & $\begin{array}{r}\text { Jabłoński, Gorazdowski } \\
2004: 32 \\
\end{array}$ \\
\hline Daphne gnidium L. & $\begin{array}{l}\text { wawrzynek } \\
\text { gnidyjski }\end{array}$ & & O; Cramp 1980: 500 \\
\hline Daucus L. & marchew & & $\begin{array}{r}\text { Zcz; Jabłoński, Gorazdowski } \\
2004: 32\end{array}$ \\
\hline $\begin{array}{l}\text { Deschampsia cespitosa } \\
\text { (L.) P.Beauv. }\end{array}$ & śmiałek darniowy & $(\mathrm{Rk}),(\mathrm{Ro}),(\mathrm{Ru})$ & Glutz 1973: 318 \\
\hline $\begin{array}{l}\text { Digitaria sanguinalis } \\
\text { (L.) Scop. }\end{array}$ & $\begin{array}{l}\text { palusznik } \\
\text { krwawy }\end{array}$ & $\begin{array}{l}(\mathrm{RzM}),(\mathrm{Ch}), \\
(\mathrm{Ru})\end{array}$ & Glutz 1973: 318 \\
\hline $\begin{array}{l}\text { Echinochloa crus-galli } \\
\text { (L.) P.Beauv. }\end{array}$ & $\begin{array}{l}\text { chwastnica } \\
\text { jednostronna }\end{array}$ & $\begin{array}{l}(\mathrm{RzM}),(\mathrm{Ch}), \\
(\mathrm{Ru})\end{array}$ & Glutz 1973: 318 \\
\hline Euphasia L. & świetlik & & Cramp 1980: 500 \\
\hline Euphorbia exigua L. & $\begin{array}{l}\text { wilczomlecz } \\
\text { drobny }\end{array}$ & $(\mathrm{RzM}),(\mathrm{Rz})$ & Glutz 1973: 318 \\
\hline Euphorbia falcata L. & $\begin{array}{l}\text { wilczomlecz } \\
\text { sierpowaty }\end{array}$ & $(\mathrm{Rz}),(\mathrm{Ch})$ & Glutz 1973: 318 \\
\hline $\begin{array}{l}\text { Fagopyrum tataricum } \\
\text { (L.) Gaertn }\end{array}$ & gryka tatarka & (Rur) & k, N; Frankiewicz 1950: 19 \\
\hline Galeopsis L. & poziewnik & & $\begin{array}{r}\text { Glutz 1973: 317, Cramp 1980: } \\
500\end{array}$ \\
\hline Galeopsis tetrahit L. & $\begin{array}{l}\text { poziewnik } \\
\text { szorstki }\end{array}$ & $\begin{array}{l}(\mathrm{RzM}),(\mathrm{Ch}), \\
(\mathrm{Ru})\end{array}$ & Glutz 1973: 318 \\
\hline
\end{tabular}




\begin{tabular}{|c|c|c|c|}
\hline Nazwa łacińska & Nazwa polska & Kategoria & Źródło \\
\hline Glycine Willd. & soja & & $\begin{array}{r}\text { Jabłoński, Gorazdowski } \\
2004: 32\end{array}$ \\
\hline Helianthus L. & słonecznik & & Dzięciołowski 1961: 14 \\
\hline $\begin{array}{l}\text { Holosteum umbellatum } \\
\text { L. }\end{array}$ & $\begin{array}{l}\text { mokrzycznik } \\
\text { baldaszkowy }\end{array}$ & (RzM), (Ch) & Glutz 1973: 317 \\
\hline Hordeum L. & jęczmień & & $\begin{array}{r}\text { Cramp 1980: 500, N; } \\
\text { Okarma 2008: } 80\end{array}$ \\
\hline Hordeum vulgare $\mathrm{L}$. & $\begin{array}{l}\text { jęczmień } \\
\text { zwyczajny }\end{array}$ & (Rk), (Rur) & Glutz 1973: 318 \\
\hline Lamium amplexicaule L. & jasnota różowa & $(\mathrm{Ch})$ & Glutz 1973: 318 \\
\hline Lolium L. & życica & & Cramp 1980: 500 \\
\hline Lolium temulentum L. & życica trwała & $(\mathrm{RzM})$ & Glutz 1973: 318 \\
\hline Malus Mill. & jabłoń & & $\begin{array}{r}\text { starta; Jabłoński, } \\
\text { Gorazdowski 2004: } 32 \\
\end{array}$ \\
\hline Medicago L. & lucerna & & $\begin{array}{r}\text { Jabłoński, Gorazdowski } \\
2004: 32\end{array}$ \\
\hline Melampyrum L. & pszeniec & & Cramp 1980: 500 \\
\hline Melampyrum arvense L. & pszeniec różowy & $(\mathrm{RzM}),(\mathrm{Ch})$ & Glutz 1973: 317 \\
\hline Melilotus albus Medik. & nostrzyk biały & $\begin{array}{l}(\mathrm{Rk}),(\mathrm{Rur}) \\
(\mathrm{Ru})\end{array}$ & Dzięciołowski 1961: 14 \\
\hline Mercurialis annua L. & szczyr roczny & $(\mathrm{Ch})$ & Glutz 1973: 318 \\
\hline $\begin{array}{l}\text { Odontites vulgaris } \\
\text { Moench }\end{array}$ & zagorzałek późny & (Ch) & Glutz 1973: 317 \\
\hline Panicum L. & proso & & $\begin{array}{r}\text { k, N; Frankiewicz 1950: } \\
\text { 19, Glutz 1973: 317, Cramp } \\
\text { 1980: 500, N; Strojny 1986: } \\
\text { 347, N; Dudziński 1988: 117, } \\
\text { Jabłoński, Gorazdowski } \\
\text { 2004: 32, N; Okarma 2008: } 80\end{array}$ \\
\hline Panicum miliaceum L. & proso zwyczajne & (Ro),(Rur) & Glutz 1973: 318 \\
\hline Papaver L. & mak & & Cramp 1980: 500 \\
\hline Papaver argemone $\mathrm{L}$. & mak piaskowy & $\begin{array}{l}(\mathrm{RzM}),(\mathrm{Ch}), \\
(\mathrm{Ru})\end{array}$ & Glutz 1973: 317 \\
\hline Papaver dubium L. & mak wątpliwy & $\begin{array}{l}(\mathrm{RzM}),(\mathrm{Ro}), \\
(\mathrm{Ch})\end{array}$ & Glutz 1973: 317 \\
\hline Papaver rhoeas L. & mak polny & $\begin{array}{l}(\mathrm{RzM}),(\mathrm{Rk}), \\
(\mathrm{Ro}),(\mathrm{Ch}),(\mathrm{Ru})\end{array}$ & Glutz 1973: 317 \\
\hline
\end{tabular}




\begin{tabular}{|c|c|c|c|}
\hline Nazwa łacińska & Nazwa polska & Kategoria & Źródło \\
\hline Papaver somniferum L. & mak lekarski & $\begin{array}{l}(\mathrm{Rk}),(\mathrm{Ro}), \\
(\mathrm{Ch}),(\mathrm{Ru})\end{array}$ & Glutz 1973: 318 \\
\hline $\begin{array}{l}\text { Pennisetum glaucum } \\
\text { (L.) R.Br. }\end{array}$ & $\begin{array}{l}\text { rosplenica } \\
\text { perłowa }\end{array}$ & $(\mathrm{Ro}),(\mathrm{Ru})$ & $\begin{array}{r}\text { Glutz 1973: 317, N; Cramp } \\
1980: 500\end{array}$ \\
\hline Persicaria L. & rdest & & $\begin{array}{r}\text { Glutz 1973: 318, N; Cramp } \\
\text { 1980: 500, Dudziński 1988: } \\
117\end{array}$ \\
\hline Petroselinum J. Hill & pietruszka & & $\begin{array}{r}\text { Zcz; Jabłoński, Gorazdowski } \\
2004: 32\end{array}$ \\
\hline $\begin{array}{l}\text { Pinus ponderosa } \\
\text { Douglas ex C.Lawson }\end{array}$ & sosna żółta & $(\mathrm{Ro}),(\mathrm{Ru})$ & Turček 1961: 45 \\
\hline Plantago L. & babka & & Cramp 1980: 500 \\
\hline Poa L. & wiechlina & & N; Cramp 1980: 500 \\
\hline Poaceae (R. Br.) Barnh. & trawy & & $\begin{array}{r}\text { N; Taczanowski 1882: 62, } \\
\text { N; Dudziński 1988: 17, N; } \\
\text { Dejonghe 2008: } 86\end{array}$ \\
\hline Reseda lutea L. & rezeda żółta & $(\mathrm{Ch}),(\mathrm{Ru})$ & Glutz 1973: 318 \\
\hline Rumex L. & szczaw & & Cramp 1980: 500 \\
\hline Rumex acetosella L. & szczaw polny & $(\mathrm{Ch})$ & Glutz 1973: 317 \\
\hline Scleranthus annuus L. & czerwiec roczny & $(\mathrm{Ch})$ & Glutz 1973: 318 \\
\hline Secale cereale $\mathrm{L}$. & żyto zwyczajne & $\begin{array}{l}\text { (Rk), (Ro), } \\
\text { (Rur) }\end{array}$ & Glutz 1973: 318 \\
\hline Senecio vulgaris L. & starzec zwyczajny & $(\mathrm{Ch}),(\mathrm{Ru})$ & Glutz 1973: 317 \\
\hline Setaria P. Beauv. & włośnica & & Cramp 1980: 500 \\
\hline $\begin{array}{l}\text { Setaria italica (L.) } \\
\text { P.Beauv. }\end{array}$ & włośnica ber & (Rk), (Rur) & Glutz 1973: 318 \\
\hline $\begin{array}{l}\text { Setaria viridis (L.) } \\
\text { P.Beauv. }\end{array}$ & włośnica zielona & $(\mathrm{Ch}),(\mathrm{Ru})$ & $\begin{array}{r}\text { Glutz 1973: 317, N; Cramp } \\
1980: 500\end{array}$ \\
\hline $\begin{array}{l}\text { Solanum americanum } \\
\text { Mill. }\end{array}$ & psianka czarna & (Ch) & Glutz 1973: 318 \\
\hline Sorghum Moench & sorgo & & N; Cramp 1980: 500 \\
\hline Spergula L. & sporek & & Cramp 1980: 500 \\
\hline Spergula arvensis L. & sporek polny & $(\mathrm{Rz}),(\mathrm{Ch}),(\mathrm{Ru})$ & Glutz 1973: 318 \\
\hline $\begin{array}{l}\text { Spergularia (Pers.) } \\
\text { J.Presl \& C.Presl }\end{array}$ & muchotrzew & & Glutz 1973: 317, Cramp 1980: \\
\hline Stachys L. & czyściec & & Cramp 1980: 500 \\
\hline
\end{tabular}




\begin{tabular}{|c|c|c|c|}
\hline Nazwa łacińska & Nazwa polska & Kategoria & Źródło \\
\hline Stachys annua (L.) L. & czyściec roczny & $(\mathrm{RzM}),(\mathrm{Rz})$ & $\begin{array}{r}\text { Glutz 1973: 317, N; Cramp } \\
\text { 1980: } 500\end{array}$ \\
\hline Stellaria L. & gwiazdnica & & $\begin{array}{r}\text { Cramp 1980: 500, Jabłoński, } \\
\text { Gorazdowski 2004: } 32\end{array}$ \\
\hline Stellaria media (L.) Vill. & $\begin{array}{l}\text { gwiazdnica } \\
\text { pospolita }\end{array}$ & $(\mathrm{Ch})$ & Glutz 1973: 317, 318 \\
\hline $\begin{array}{l}\text { Taraxacum officinale } \\
\text { Webb }\end{array}$ & mniszek lekarski & $(\mathrm{Rk}),(\mathrm{Ch}),(\mathrm{Ru})$ & $\begin{array}{r}\text { Jabłoński, Gorazdowski } \\
2004: 32\end{array}$ \\
\hline Triticum L. & pszenica & & $\begin{array}{r}\text { k, N; Frankiewicz 1950: 19, } \\
\text { N; Jabłoński, Gorazdowski } \\
\text { 2004: 32, N; Okarma 2008: } 80\end{array}$ \\
\hline Triticum vulgare Vill. & $\begin{array}{l}\text { pszenica } \\
\text { zwyczajna }\end{array}$ & (Rk), (Rur) & Glutz 1973: 318 \\
\hline Urtica L. & pokrzywa & & $\begin{array}{r}\text { Jabłoński, Gorazdowski } \\
2004: 32\end{array}$ \\
\hline Vicia L. & wyka & & Cramp 1980: 500 \\
\hline Zea L. & kukurydza & & Dzięciołowski 1961: 14 \\
\hline Ziziphus jujuba Mill. & głożyna pospolita & $(\mathrm{Ru})$ & Turček 1961: 72 \\
\hline \multicolumn{4}{|c|}{ Perdix perdix L., kuropatwa } \\
\hline Achillea L. & krwawnik & & $\begin{array}{r}\text { k, Pę posiekane, pisklęta; } \\
\text { Szczepkowski 1958: 4, } \\
\text { k, posiekany, pisklęta; } \\
\text { Staszek 1961: 17, Jabłoński, } \\
\text { Gorazdowski 2004: } 32\end{array}$ \\
\hline Achillea millefolium L. & $\begin{array}{l}\text { krwawnik } \\
\text { pospolity }\end{array}$ & $\begin{array}{l}(\mathrm{RzM}),(\mathrm{Rk}), \\
(\mathrm{Ro}),(\mathrm{Ru})\end{array}$ & L; Szczepkowski 1953: 88 \\
\hline Agrostemma L. & kąkol & & Szczepkowski 1953: 88 \\
\hline Agrostemma githago L. & kąkol polny & $\begin{array}{l}(\mathrm{RzM}),(\mathrm{Rz}) \\
(\mathrm{Ro}),(\mathrm{Ru})\end{array}$ & N; Wiktor 1905: 12 \\
\hline Alopecurus L. & wyczyniec & & $\begin{array}{r}\text { Zcz; Oko, Wójtkowski 1960: } \\
317 \\
\end{array}$ \\
\hline $\begin{array}{l}\text { Alopecurus } \\
\text { myosuroides Huds. }\end{array}$ & wyczyniec polny & (Ch) & $\begin{array}{r}\text { N; Oko, Wójtkowski 1960: } \\
317\end{array}$ \\
\hline Alopecurus pratensis L. & $\begin{array}{l}\text { wyczyniec } \\
\text { łąkowy }\end{array}$ & (Rk), (Rur) & $\begin{array}{r}\text { N; Oko, Wójtkowski 1960: } \\
317\end{array}$ \\
\hline
\end{tabular}




\begin{tabular}{|c|c|c|c|}
\hline Nazwa łacińska & Nazwa polska & Kategoria & Źródło \\
\hline $\begin{array}{l}\text { Amaranthus retroflexus } \\
\text { L. }\end{array}$ & szarłat szorstki & $(\mathrm{Ch}),(\mathrm{Ru})$ & $\begin{array}{r}\text { N; Oko, Wójtkowski 1960: } \\
\text { 318, N listopad, L grudzień - } \\
\text { luty; Oko 1962a: 25, 26, Oko } \\
1963: 340\end{array}$ \\
\hline Anagallis arvensis $\mathrm{L}$. & kurzyślad polny & (RzM), (Ch) & $\begin{array}{r}\text { N; Oko, Wójtkowski 1960: } \\
\text { 317, Oko1963: } 340\end{array}$ \\
\hline Anethum L. & koper & & $\begin{array}{r}\text { Zcz; Jabłoński, Gorazdowski } \\
2004: 32\end{array}$ \\
\hline $\begin{array}{l}\text { Anthoxanthum } \\
\text { odoratum L. }\end{array}$ & tomka wonna & $\begin{array}{l}(\mathrm{RzM}),(\mathrm{Rk}), \\
(\mathrm{Ru})\end{array}$ & L marzec; Oko 1962a: 27 \\
\hline $\begin{array}{l}\text { Arctostaphylos uva-ursi } \\
\text { (L.) Spreng. }\end{array}$ & mącznica lekarska & $\begin{array}{l}(\mathrm{RzM}),(\mathrm{Rz}), \\
(\mathrm{Ro}),(\mathrm{Ru})\end{array}$ & Bartkowiak 1970: 256 \\
\hline $\begin{array}{l}\text { Arrhenatherum elatius } \\
\text { (L.) P.Beauv. ex } \\
\text { J.Presl \& C.Presl. }\end{array}$ & rajgras wyniosły & $(\mathrm{Rk}),(\mathrm{Ru})$ & $\begin{array}{r}\text { N, Zcz; Oko, Wójtkowski } \\
1960: 317\end{array}$ \\
\hline Asperugo procumbens L. & $\begin{array}{l}\text { lepczyca } \\
\text { rozesłana }\end{array}$ & (RzM), (Rz) & N; Oko 1963: 339, 340 \\
\hline Asteraceae Dum. & astrowate & & L; Oko 1963: 339 \\
\hline Atriplex L. & łoboda & & $\begin{array}{r}\text { Szczepkowski 1953: 88, Zcz; } \\
\text { Oko, Wójtkowski 1960: } 317\end{array}$ \\
\hline Avena L. & owies & & $\begin{array}{r}\text { Szczepkowski 1953: 88, N; } \\
\text { Moraczewska 1955: 6, N; } \\
\text { Bujna 1958: 29, N w postaci } \\
\text { skiełkowanej; Oko 1963: } \\
\text { 339, N; Luniak 1965: 5, } \\
\text { N; Pomarnacki 1969: 14, } \\
\text { Chlewski 1970: 7, Biały 1989: } \\
\text { 10, k; Biały 1997: } 23\end{array}$ \\
\hline Avena sativa $\mathrm{L}$. & owies zwyczajny & $\begin{array}{l}\text { (Rk), (Ro), } \\
\text { (Rur) }\end{array}$ & $\begin{array}{r}\text { N; Oko, Wójtkowski 1960: } \\
\text { 317, Oko 1963: } 340\end{array}$ \\
\hline $\begin{array}{l}\text { Berberis aquifolium } \\
\text { Pursh }\end{array}$ & $\begin{array}{l}\text { mahonia } \\
\text { pospolita }\end{array}$ & $(\mathrm{Ro}),(\mathrm{Ru})$ & Turček 1961: 40 \\
\hline
\end{tabular}




\begin{tabular}{|c|c|c|c|}
\hline Nazwa łacińska & Nazwa polska & Kategoria & Źródło \\
\hline Beta L. & burak & & $\begin{array}{r}\text { Wiktor 1905: 12, Knothe } \\
\text { 1952a: 8, Bednorz, Bogucki } \\
\text { 1961: 24, Dzięciołowski 1961: } \\
\text { 14, pokrojone; Kopijowska } \\
\text { 1961: 30, Nowak 1961: } \\
\text { 170, posiekane; Popławski } \\
\text { 1962: 86, 89, k, posiekane; } \\
\text { Sikorski 1963: 5, posiekane; } \\
\text { Dzieduszycki 1968: 10, Biały } \\
1989: 10\end{array}$ \\
\hline $\begin{array}{l}\text { Beta vulgaris subsp. } \\
\text { vulgaris }\end{array}$ & burak pastewny & (Rk), (Rur) & $\begin{array}{r}\text { Bk; Chlewski 1970: 7, Bk; } \\
\text { Feil1 989: } 24\end{array}$ \\
\hline $\begin{array}{l}\text { Beta vulgaris subsp. } \\
\text { vulgaris convar. } \\
\text { vulgaris var. altissima }\end{array}$ & burak cukrowy & (Rk), (Rur) & $\begin{array}{l}\text { Kryspin 1955: 4, Ko; Oko, } \\
\text { Wójtkowski 1960: 317, Bk; } \\
\text { Chlewski 1970: 7, Bk; Feil } \\
\text { 1989: 24, k; Biały 1997: } 23\end{array}$ \\
\hline Brassica L. & kapusta & & $\begin{array}{r}\text { Bednorz, Bogucki 1961: } \\
\text { 24, Nowak 1961: 170, } \\
\text { L; Popławski 1962: 89, } \\
\text { k; Sikorski 1963: 5, L; } \\
\text { Dzieduszycki 1968: 10, k; } \\
\text { Biały 1997: } 23\end{array}$ \\
\hline $\begin{array}{l}\text { Brassica napus L. var. } \\
\text { napobrassica }\end{array}$ & brukiew & (Rk), (Rur) & $\begin{array}{r}\text { Nowak 1961: 170, Biały 1989: } \\
\text { 10, Bk; Feil 1989: 24, w; Biały } \\
\text { 1997: } 23\end{array}$ \\
\hline $\begin{array}{l}\text { Brassica napus var. } \\
\text { napus }\end{array}$ & rzepak & $\begin{array}{l}\text { (Rk), (Ch), } \\
\text { (Rur) }\end{array}$ & $\begin{array}{r}\text { listopad; Oko 1962a: 25, } \\
\text { L; Popławski 1962: 89, } \\
\text { k, L; Sikorski 1963: 5, L; } \\
\text { Dzieduszycki 1968:10, L; } \\
\text { Panek 1988: 15, N; Behnke } \\
\text { 1995: 71, N; Głębocki 2010: }\end{array}$ \\
\hline
\end{tabular}




\begin{tabular}{|c|c|c|c|}
\hline Nazwa łacińska & Nazwa polska & Kategoria & Źródło \\
\hline Brassica oleracea L. & $\begin{array}{l}\text { kapusta } \\
\text { warzywna }\end{array}$ & (Rk), (Rur) & $\begin{array}{r}\text { Biały 1989: 10, Feil 1989: } \\
\text { 24, L; Knothe 1952a: 8, } \\
\text { pokrojone; Kopijowska } \\
\text { 1961: 30, Popławski 1962: } \\
\text { 86, Chlewski 1970: 7,L; } \\
\text { Bochniarzowa 1974: 7, Biały } \\
\text { 1989: 10, Feil 1989: 24, k; } \\
\text { Biały 1997: 23, Pilarczyk } \\
\text { 2006: 48, Chojnowski 2011: }\end{array}$ \\
\hline $\begin{array}{l}\text { Brassica oleracea var. } \\
\text { gemmifera (DC.) } \\
\text { Zenker }\end{array}$ & brukselka & (Rk), (Rur) & Chlewski 1970: 7 \\
\hline $\begin{array}{l}\text { Brassica oleracea L. var. } \\
\text { sabellica L. }\end{array}$ & jarmuż & (Rk), (Rur) & $\begin{array}{r}\text { Dzięciołowski 1961: } \\
\text { 14, k; Sikorski 1963: }, \\
\text { Dzieduszycki 1968: 10, } \\
\text { Chlewski 1970: 7, Feil } \\
\text { 1989: 24, w; Biały 1997: 23, } \\
\text { Pilarczyk 2006: } 48\end{array}$ \\
\hline Bromus L. & stokłosa & & $\begin{array}{r}\text { Zcz; Oko, Wójtkowski } 1960: \\
317\end{array}$ \\
\hline Bromus inermis Leyss. & stokłosa bezostna & (Ch) & $\begin{array}{r}\text { N; Oko, Wójtkowski } 1960: \\
317\end{array}$ \\
\hline Bromus hordeaceus L. & stokłosa miękka & (Ch) & $\begin{array}{l}\text { N; Oko, Wójtkowski 1960: } \\
\text { 317, L, marzec; Oko 1962a: }\end{array}$ \\
\hline $\begin{array}{l}\text { Buglossoides arvensis } \\
\text { (L.) I.M.Johnst. }\end{array}$ & nawrot polny & (Ch) & $\begin{array}{r}\text { Moraczewska 1955: 6, Bujna } \\
1958: 29\end{array}$ \\
\hline Cannabis L. & konopia & & Pomarnacki 1955: 7 \\
\hline Carduus L. & oset & & $\begin{array}{r}\text { N; Wiktor 1905: 12, } \\
\text { Szczepkowski 1953: } 88\end{array}$ \\
\hline Centaurea cyanus L. & chaber bławatek & $\begin{array}{l}\text { (RzM), (Rk), } \\
(\mathrm{Ro}),(\mathrm{Ch}),(\mathrm{Ru})\end{array}$ & $\begin{array}{r}\text { N; Oko, Wójtkowski 1960: } \\
\text { 317, N; Oko1962: 17, N, } \\
\text { listopad; Oko 1962a: 25, N; } \\
\text { Oko 1963: 339, } 340\end{array}$ \\
\hline Centaurea scabiosa L. & $\begin{array}{l}\text { chaber } \\
\text { driakiewnik }\end{array}$ & $(\mathrm{Rk}),(\mathrm{Ro}),(\mathrm{Ch})$ & $\begin{array}{r}\text { Moraczewska 1955: 6, Bujna } \\
1958: 29\end{array}$ \\
\hline
\end{tabular}




\begin{tabular}{|c|c|c|c|}
\hline Nazwa łacińska & Nazwa polska & Kategoria & Źródło \\
\hline Cerastium L. & rogownica & & $\begin{array}{r}\text { Szczepkowski 1953: 88, } \\
\text { Bujna 1958: } 29\end{array}$ \\
\hline $\begin{array}{l}\text { Cerastium } \\
\text { semidecandrum L. }\end{array}$ & $\begin{array}{l}\text { rogownica } \\
\text { pięciopręcikowa }\end{array}$ & (Ch) & N, listopad; Oko 1962a: 25 \\
\hline Cerastium arvense $\mathrm{L}$. & rogownica polna & (Ch) & $\begin{array}{r}\text { N; Oko, Wójtkowski 1960: } \\
318\end{array}$ \\
\hline Chenopodium L. & komosa & & $\begin{array}{r}\text { Moraczewska 1955: 6, } \\
\text { Bujna 1958: 29, Zcz; Oko, } \\
\text { Wójtkowski 1960: } 317\end{array}$ \\
\hline Chenopodium album L. & komosa biała & $(\mathrm{Rk}),(\mathrm{Ch}),(\mathrm{Ru})$ & $\begin{array}{l}\text { N; Oko, Wójtkowski 1960: } \\
\text { 318, N, listopad, styczeń - } \\
\text { marzec; Oko 1962a: 25, } 27\end{array}$ \\
\hline $\begin{array}{l}\text { Chenopodium } \\
\text { polyspermum } \mathrm{L} .\end{array}$ & $\begin{array}{l}\text { komosa } \\
\text { wielonasienna }\end{array}$ & $(\mathrm{RzM}),(\mathrm{Ch})$ & $\begin{array}{l}\mathrm{N} \text {, listopad, marzec, } \mathrm{L} \\
\text { grudzień; Oko 1962a: } 25-27\end{array}$ \\
\hline Chenopodiaceae Vent & komosowate & & L; Oko 1963: 339 \\
\hline Cirsium Mill & ostrożeń & & Szczepkowski 1953: 88 \\
\hline Crataegus L. & głóg & & N; Okarma 2008: 331 \\
\hline Cucumis L. & ogórek & & $\begin{array}{r}\text { Jabłoński, Gorazdowski } \\
2004: 32\end{array}$ \\
\hline $\begin{array}{l}\text { Cynara cardunculus } \\
\text { subsp. flavescens } \\
\text { Wiklund }\end{array}$ & $\begin{array}{l}\text { karczoch } \\
\text { zwyczajny }\end{array}$ & $(\mathrm{Ru})$ & Dzięciołowski 1961: 14 \\
\hline $\begin{array}{l}\text { Cytisus scoparius (L.) } \\
\text { Link }\end{array}$ & $\begin{array}{l}\text { żarnowiec } \\
\text { miotlasty }\end{array}$ & $(\mathrm{Rk}),(\mathrm{Ro}),(\mathrm{Ru})$ & N; Jeleniak 2002: 21 \\
\hline Daucus L. & marchew & & $\begin{array}{r}\text { Wiktor 1905: 12, Bednorz, } \\
\text { Bogucki 1961: 24, pokrojona; } \\
\text { Kopijowska 1961: 30, Nowak } \\
\text { 1961: 170, Popławski 1962: } \\
\text { 86, 89, k, Bk, posiekane; } \\
\text { Sikorski 1963: 5, pokrojona; } \\
\text { Biały 1989: 10, Zcz; } \\
\text { Jabłoński, Gorazdowski } \\
2004: 32\end{array}$ \\
\hline
\end{tabular}




\begin{tabular}{|c|c|c|c|}
\hline Nazwa łacińska & Nazwa polska & Kategoria & Źródło \\
\hline Daucus carota $\mathrm{L}$. & $\begin{array}{l}\text { marchew } \\
\text { zwyczajna }\end{array}$ & $\begin{array}{l}(\mathrm{Rk}),(\mathrm{Ru}), \\
\text { (Rur) }\end{array}$ & $\begin{array}{r}\text { Zcz; Oko, Wójtkowski 1960: } \\
\text { 317, Bk, listopad; Oko 1962a: } \\
\text { 25, posiekana; Dzieduszycki } \\
\text { 1968: 10, Chlewski 1970: 7, } \\
\text { Feil 1989: 24, k; Biały 1997: }\end{array}$ \\
\hline Delphinium consolida L. & ostróżeczka polna & $(\mathrm{Rz}),(\mathrm{Ro}),(\mathrm{Ru})$ & Glutz 1973: 273 \\
\hline $\begin{array}{l}\text { Echinochloa crus-galli } \\
\text { (L.) P.Beauv. }\end{array}$ & $\begin{array}{l}\text { chwastnica } \\
\text { jednostronna }\end{array}$ & $\begin{array}{l}(\mathrm{RzM}),(\mathrm{Ch}), \\
(\mathrm{Ru})\end{array}$ & $\begin{array}{r}\text { N, Zcz; Oko, Wójtkowski } \\
\text { 1960: 317, N; Oko 1962: 17, } \\
\text { N, L, listopad, Oko 1962a: } \\
\text { 25, Oko 1963: 340; }\end{array}$ \\
\hline $\begin{array}{l}\text { Elymus repens (L.) } \\
\text { Gould }\end{array}$ & perz właściwy & $(\mathrm{Ch}),(\mathrm{Ru})$ & L, styczeń, luty; Oko 1962a: \\
\hline Euphorbia cyparissias L. & $\begin{array}{l}\text { wilczomlecz } \\
\text { sosnka }\end{array}$ & $\begin{array}{l}\text { (Rk), (Ro), } \\
(\mathrm{Ch}),(\mathrm{Ru})\end{array}$ & Szczepkowski 1953: 88 \\
\hline Fabaceae Lindl. & bobowate & & L; Oko 1963: 339 \\
\hline Fagopyrum Mill. & gryka & & $\begin{array}{r}\text { Dzięciołowski 1961: 14, } \\
\text { Nowak 1961: 127, Chlewski } \\
\text { 1970: } 7\end{array}$ \\
\hline $\begin{array}{l}\text { Festuca pratensis } \\
\text { Huds. }\end{array}$ & kostrzewa łąkowa & $(\mathrm{Ru})$ & $\begin{array}{l}\text { N, Zcz; Oko, Wójtkowski } \\
\text { 1960: 317, N; Oko 1962: } 17\end{array}$ \\
\hline Fragaria L. & poziomka & & Nowak 1961: 127 \\
\hline Galeopsis tetrahit L. & $\begin{array}{l}\text { poziewnik } \\
\text { szorstki }\end{array}$ & $\begin{array}{l}(\mathrm{RzM}),(\mathrm{Ch}), \\
(\mathrm{Ru})\end{array}$ & Bujna 1958: 29 \\
\hline Glycine Willd. & soja & & $\begin{array}{r}\text { Jabłoński, Gorazdowski } \\
2004: 32 \\
\end{array}$ \\
\hline Helianthus L. & słonecznik & & N; Głębocki 2010: 36 \\
\hline Helianthus tuberosus L. & $\begin{array}{l}\text { słonecznik } \\
\text { bulwiasty, } \\
\text { topinambur }\end{array}$ & $(\mathrm{Rk}),(\mathrm{Ro}),(\mathrm{Ru})$ & $\begin{array}{r}\text { Buksiński 1958: 42, Kaj 1961: } \\
\text { 2, Ortwein 1964: 15, Bk; } \\
\text { Chlewski 1970: } 7\end{array}$ \\
\hline
\end{tabular}




\begin{tabular}{|c|c|c|c|}
\hline Nazwa łacińska & Nazwa polska & Kategoria & Źródło \\
\hline Hordeum L. & jęczmień & & $\begin{array}{r}\text { Szczepkowski 1953: 88, } \\
\text { N; Moraczewska 1955: } \\
\text { 6, N; Bujna 1958: 29, } \\
\text { Dzięciołowski 1961: 14, } \\
\text { N; Oko 1962: 17, L, Zcz, } \\
\text { grudzień, styczeń - luty; } \\
\text { Oko 1962a: 26, N; Popławski } \\
\text { 1962: 32, N w postaci } \\
\text { skiełkowanej; Oko 1963: } \\
\text { 339, Chlewski 1970: 7, Biały } \\
\text { 1989: 10, k; Biały 1997: 23, N; } \\
\text { Okarma 2008: 331 }\end{array}$ \\
\hline Hordeum vulgare L. & $\begin{array}{l}\text { jęczmień } \\
\text { zwyczajny }\end{array}$ & (Rk), (Rur) & $\begin{array}{r}\text { N; Oko, Wójtkowski 1960: } \\
\text { 317, N, listopad; Oko 1962a: } \\
25, \text { Oko 1963: } 340\end{array}$ \\
\hline Ilex aquifolium $\mathrm{L}$. & $\begin{array}{l}\text { ostrokrzew } \\
\text { kolczasty }\end{array}$ & $(\mathrm{Ro}),(\mathrm{Ru})$ & Bartkowiak 1970: 254 \\
\hline Juncus bufonius L. & sit dwudzielny & $(\mathrm{Ch})$ & Oko 1963: 340 \\
\hline Juniperus communis L. & jałowiec pospolity & $(\mathrm{Rk}),(\mathrm{Ro}),(\mathrm{Ru})$ & $\begin{array}{r}\text { Turček 1961: 36, Bartkowiak } \\
\text { 1970: } 248\end{array}$ \\
\hline Juniperus virginiana L. & $\begin{array}{l}\text { jałowiec } \\
\text { wirginijski }\end{array}$ & $(\mathrm{Ro}),(\mathrm{Ru})$ & Bartkowiak 1970: 248 \\
\hline Lathyrus pratensis L. & groszek żółty & $(\mathrm{Ru})$ & Oko 1963: 340 \\
\hline Leontodon autumnalis L. & $\begin{array}{l}\text { brodawnik } \\
\text { jesienny }\end{array}$ & (Ch) & Oko 1963: 340 \\
\hline Linum L. & len & & Dzięciołowski 1961: 14 \\
\hline Lolium temulentum L. & życica trwała & (Ch), (Rur) & $\begin{array}{l}\text { N, Zcz; Oko, Wójtkowski } \\
\text { 1960: 317, Zcz, styczeń - } \\
\text { marzec; Oko 1962a: 26, } 27\end{array}$ \\
\hline Lupinus L. & łubin & & Behnke 1995: 70 \\
\hline Lycium barbarum $\mathrm{L}$. & $\begin{array}{l}\text { kolcowój } \\
\text { pospolity }\end{array}$ & $(\mathrm{Ro}),(\mathrm{Ru})$ & Turček 1961: 40 \\
\hline Malus Mill. & jabłoń & & $\begin{array}{r}\text { starte; Jabłoński, } \\
\text { Gorazdowski 2004: } 32\end{array}$ \\
\hline
\end{tabular}




\begin{tabular}{|c|c|c|c|}
\hline Nazwa łacińska & Nazwa polska & Kategoria & Źródło \\
\hline Medicago L. & lucerna & & $\begin{array}{r}\text { Moraczewska 1955: 6, Bujna } \\
\text { 1958: 29, L, styczeń - luty; } \\
\text { Oko 1962a: 26, suszone; } \\
\text { Popławski 1962: 89, L; } \\
\text { Chlewski 1970: 7, Jabłoński, } \\
\text { Gorazdowski 2004: } 32\end{array}$ \\
\hline Melilotus (L.) Mill. & nostrzyk & & $\begin{array}{r}\text { Zcz; Oko, Wójtkowski 1960: } \\
317 \\
\end{array}$ \\
\hline Melilotus albus Medik. & nostrzyk biały & $\begin{array}{l}(\mathrm{Rk}),(\mathrm{Ru}), \\
\text { (Rur) }\end{array}$ & Dzięciołowski 1961: 14 \\
\hline Myosotis scorpioides L. & $\begin{array}{l}\text { niezapominajka } \\
\text { błotna }\end{array}$ & (Ro), (Ch) & Bujna 1958: 29 \\
\hline $\begin{array}{l}\text { Ornithopus satious } \\
\text { Brot. }\end{array}$ & $\begin{array}{l}\text { saradela } \\
\text { pastewna }\end{array}$ & (Rk), (Rur) & $\begin{array}{r}\text { N; Oko, Wójtkowski 1960: } \\
317\end{array}$ \\
\hline Oxalis L. & szczawik & & Moraczewska 1955: 6 \\
\hline Panicum L. & proso & & $\begin{array}{r}\text { Pomarnacki 1955: 7, N; } \\
\text { Sokołowski 1958: 155, N; } \\
\text { Nowak 1961: 127, Chlewski } \\
\text { 1970: 7, N; Sokołowski 1972: } \\
\text { 123, Jabłoński, Gorazdowski } \\
\text { 2004: 32, N; Okarma 2008: }\end{array}$ \\
\hline Panicum miliaceum L. & proso zwyczajne & $\begin{array}{l}\text { (Rk), (Ro), } \\
\text { (Rur) }\end{array}$ & Behnke 1995: 17 \\
\hline Papaver rhoeas L. & mak polny & $\begin{array}{l}\text { (RzM), (Rk), } \\
(\mathrm{Ro}),(\mathrm{Ch}),(\mathrm{Ru})\end{array}$ & $\begin{array}{r}\text { N; Wiktor 1905: 12, N; } \\
\text { Szczepkowski 1953: 88, N; } \\
\text { Oko 1963: 339, } 340\end{array}$ \\
\hline Petroselinum J. Hill & pietruszka & & $\begin{array}{r}\text { Zcz; Jabłoński, Gorazdowski } \\
2004: 32 \\
\end{array}$ \\
\hline Plantago major L. & babka zwyczajna & $(\mathrm{Ch}),(\mathrm{Ru})$ & Glutz 1973: 273 \\
\hline Plantago lanceolata L. & $\begin{array}{l}\text { babka } \\
\text { lancelowata }\end{array}$ & $(\mathrm{Ch}),(\mathrm{Ru})$ & $\begin{array}{r}\text { Szczepkowski 1953: 88, } \\
\text { Glutz 1973: } 273\end{array}$ \\
\hline
\end{tabular}




\begin{tabular}{|c|c|c|c|}
\hline Nazwa łacińska & Nazwa polska & Kategoria & Źródło \\
\hline Persicaria L. & rdest & & $\begin{array}{r}\text { Moraczewska 1955: 6, } \\
\text { Bujna 1958: 29, N; Oko, } \\
\text { Wójtkowski 1960: 317,N, } \\
\text { listopad, styczeń - luty, L, } \\
\text { grudzień; Oko 1962a: 25, } \\
\text { 26, N; Oko 1963: 339, 340, } \\
\text { Cramp 1980: 490, N; Okarma } \\
\text { 2008: 74, N, styczeń, luty; } \\
\text { Oko 1962a: 26, N; Oko 1962: } \\
\text { 17, Oko 1963: 340, Glutz } \\
\text { 1973: } 273\end{array}$ \\
\hline Poa annua L. & wiechlina roczna & (Ch) & $\begin{array}{r}\text { marzec; Oko 1962a: 27, } \\
\text { Cramp 1980: 490, N; } \\
\text { Okarma 2008: } 74\end{array}$ \\
\hline Poaceae (R. Br.) Barnh. & trawy & & $\begin{array}{r}\text { młode; Wiktor 1905: } \\
\text { 12, Szczepkowski 1953: } \\
\text { 88, L; Bujna 1958: 29, L; } \\
\text { Sokołowski 1958: 154, L; } \\
\text { Nowak 1961: 127, Popławski } \\
\text { 1962: 31, L; Chlewski 1970: } \\
\text { 7, L; Sokołowski 1972: 123, } \\
\text { Cramp 1980: 490, Madej } \\
\text { 2007: 118, L, zielone; } \\
\text { Dejonghe 2008: 86, L; } \\
\text { Okarma 2008: 74 }\end{array}$ \\
\hline Prunus spinosa L. & śliwa tarnina & $(\mathrm{Rk}),(\mathrm{Ro}),(\mathrm{Ru})$ & N; Okarma 2008: 331 \\
\hline Ranunculaceae Juss. & jaskrowate & & L; Oko 1963: 339 \\
\hline Ranunculus acris L. & jaskier ostry & $\begin{array}{l}\text { (Rk), (Ro), } \\
(\mathrm{Ch}),(\mathrm{Ru})\end{array}$ & Oko 1963: 340 \\
\hline Ranunculus repens L. & jaskier rozłogowy & $\begin{array}{l}\text { (RzM), (Rk), } \\
(\mathrm{Ch}),(\mathrm{Ro})\end{array}$ & Oko 1963: 340 \\
\hline Ribes rubrum L. & $\begin{array}{l}\text { porzeczka } \\
\text { zwyczajna }\end{array}$ & $(\mathrm{Rk}),(\mathrm{Ru})$ & Turček 1961: 54 \\
\hline Robinia pseudoacacia L. & grochodrzew & & N; Stankiewicz 2000a: 26 \\
\hline Rosa canina $\mathrm{L}$ & róża dzika & $(\mathrm{Rk}),(\mathrm{Ro}),(\mathrm{Ru})$ & $\begin{array}{r}\text { Bartkowiak 1970: 252, N; } \\
\text { Okarma 2008: } 331\end{array}$ \\
\hline Sambucus ebulus L. & bez hebd & $(\mathrm{Ro}),(\mathrm{Ru})$ & Turček 1961: 62 \\
\hline
\end{tabular}




\begin{tabular}{|c|c|c|c|}
\hline Nazwa łacińska & Nazwa polska & Kategoria & Źródło \\
\hline Scleranthus annuus L. & czerwiec roczny & $(\mathrm{Ch})$ & $\begin{array}{r}\text { N; Oko, Wójtkowski 1960: } \\
\text { 317, Oko 1963: } 340\end{array}$ \\
\hline Secale L. & żyto & & $\begin{array}{r}\text { Szczepkowski 1953: 88, N; } \\
\text { Moraczewska 1955: 6, N; } \\
\text { Bujna 1958: 29, L, grudzień, } \\
\text { marzec; Oko 1962a: 26, 27, } \\
\text { N; Pomarnacki 1969: } 14\end{array}$ \\
\hline Secale cereale $\mathrm{L}$. & żyto zwyczajne & $\begin{array}{l}\text { (Rk), (Ro), } \\
\text { (Rur) }\end{array}$ & N; Oko, Wójtkowski 1960: \\
\hline $\begin{array}{l}\text { Setaria viridis (L.) } \\
\text { P.Beauv. }\end{array}$ & włośnica zielona & $(\mathrm{Ch}),(\mathrm{Ru})$ & $\begin{array}{r}\text { Bujna 1958: 29, N, Zcz; Oko, } \\
\text { Wójtkowski 1960: 317, N; } \\
\text { Oko 1962: 17, N, listopad, } \\
\text { Zcz, styczeń - luty; Oko } \\
\text { 1962a: 25, 26, Oko 1963: } 340\end{array}$ \\
\hline Sinapis L. & gorczyca & & Dzięciołowski 1961: 14 \\
\hline Sinapis arvensis L. & gorczyca polna & $\begin{array}{l}(\mathrm{RzM}),(\mathrm{Rk}), \\
(\mathrm{Ch})\end{array}$ & $\begin{array}{r}\text { N; Oko, Wójtkowski } 1960: \\
317\end{array}$ \\
\hline Solanum tuberosum L. & ziemniak & & $\begin{array}{r}\text { Wiktor 1905: 12, O, listopad; } \\
\text { Oko 1962a: 25, parowane; } \\
\text { Popławski 1962: } 89\end{array}$ \\
\hline Sorbus L. & jarząb & & N; Okarma 2008: 331 \\
\hline \multirow[t]{2}{*}{ Sorbus aucuparia L. } & jarząb pospolity & $(\mathrm{Rk}),(\mathrm{Ro}),(\mathrm{Ru})$ & Bartkowiak 1970: 251, O; \\
\hline & & & Stankiewicz 2000a: 27 \\
\hline Spergula arvensis L. & sporek polny & $(\mathrm{Rz}),(\mathrm{Ch}),(\mathrm{Ru})$ & $\begin{array}{r}\text { listopad; Oko 1962a: 25, N; } \\
\text { Oko 1963: 339, } 340\end{array}$ \\
\hline Stellaria L. & gwiazdnica & & $\begin{array}{r}\text { Jabłoński, Gorazdowski } \\
2004: 32\end{array}$ \\
\hline \multirow[t]{2}{*}{ Stellaria media (L.) Vill. } & $\begin{array}{l}\text { gwiazdnica } \\
\text { pospolita }\end{array}$ & $(\mathrm{Ch}),(\mathrm{Ru})$ & L; Szczepkowski 1953: 88, \\
\hline & & & $\begin{array}{r}\text { Moraczewska 1955: 6, } \\
\text { Bujna 1958: 29, N; Oko, } \\
\text { Wójtkowski 1960: 317, } \\
\text { Cramp 1980: 490, N; Okarma } \\
2008: 74\end{array}$ \\
\hline $\begin{array}{l}\text { Symphoricarpos albus } \\
\text { (L.) S.F.Blake }\end{array}$ & śnieguliczka biała & (Rk), (Ro) & Turček 1961: 65 \\
\hline
\end{tabular}




\begin{tabular}{|c|c|c|c|}
\hline Nazwa łacińska & Nazwa polska & Kategoria & Źródło \\
\hline $\begin{array}{l}\text { Taraxacum officinale } \\
\text { Webb }\end{array}$ & mniszek lekarski & $(\mathrm{Rk}),(\mathrm{Ch}),(\mathrm{Ru})$ & $\begin{array}{r}\text { L; Szczepkowski 1953: 88, } \\
\text { N; Oko, Wójtkowski 1960: } \\
\text { 317, Jabłoński, Gorazdowski } \\
2004: 32\end{array}$ \\
\hline Tilia cordata Mill. & lipa drobnolistna & $(\mathrm{Rk}),(\mathrm{Ro}),(\mathrm{Ru})$ & O; Stankiewicz 2000: 23 \\
\hline Tilia platyphyllos Scop. & lipa szerokolistna & $(\mathrm{Rk}),(\mathrm{Ro}),(\mathrm{Ru})$ & O; Stankiewicz 2000: 23 \\
\hline Trifolium L. & koniczyna & & $\begin{array}{r}\text { Moraczewska 1955: 6, Zcz; } \\
\text { Oko, Wójtkowski 1960: 317, } \\
\text { Oko 1963: 340, L; Chlewski } \\
\text { 1970: 7, Cramp 1980: 490, } \\
\text { Madej 2007: 118, Okarma } \\
2008: 74\end{array}$ \\
\hline Trifolium arvense L. & koniczyna polna & $(\mathrm{Rk}),(\mathrm{Ro}),(\mathrm{Ch})$ & $\begin{array}{r}\text { N; Oko, Wójtkowski 1960: } \\
317 \\
\end{array}$ \\
\hline Trifolium pratense L. & koniczyna łąkowa & $\begin{array}{l}\text { (Rk), (Ro), } \\
\text { (Rur) }\end{array}$ & $\begin{array}{r}\text { N; Oko, Wójtkowski 1960: } \\
317 \\
\end{array}$ \\
\hline Trifolium repens L. & koniczyna biała & $\begin{array}{l}\text { (Rk), (Ro), } \\
\text { (Ch), (Rur) }\end{array}$ & $\begin{array}{r}\text { N; Oko, Wójtkowski 1960: } \\
\text { 317, Zcz, styczeń - luty; Oko } \\
\text { 1962a: 26, Oko 1963: } 340\end{array}$ \\
\hline Triticum L. & pszenica & & $\begin{array}{r}\text { pisklęta; Wiktor 1905: 74, } \\
\text { Szczepkowski 1953: 88, } \\
\text { N; Moraczewska 1955: 6, } \\
\text { Pomarnacki 1955: 7, N; Bujna } \\
\text { 1958: 29, Nowak 1961: 127, } \\
\text { N; Oko 1962: 17, L, grudzień, } \\
\text { marzec; Oko 1962: 26, 27, } \\
\text { N; Popławski 1962: 32, N } \\
\text { w postaci skiełkowanej; Oko } \\
\text { 1963: 339, Chlewski 1970: 7, } \\
\text { Biały 1989: 10, k; Biały 1997: } \\
\text { 23, Jabłoński, Gorazdowski } \\
\text { 2004: 32, N; Okarma 2008: } \\
\text { 331, N; Głębocki 2010: } 36\end{array}$ \\
\hline Triticum vulgare Vill. & $\begin{array}{l}\text { pszenica } \\
\text { zwyczajna }\end{array}$ & (Rk), (Rur) & $\begin{array}{r}\text { N; Oko, Wójtkowski 1960: } \\
\text { 317, N, październik; Oko } \\
\text { 1962a: 25, Oko 1963: } 340\end{array}$ \\
\hline Urtica L. & pokrzywa & & $\begin{array}{r}\text { suszona; Popławski 1962: } \\
\text { 89, Jabłoński, Gorazdowski } \\
2004: 32\end{array}$ \\
\hline
\end{tabular}




\begin{tabular}{|c|c|c|c|}
\hline Nazwa łacińska & Nazwa polska & Kategoria & Źródło \\
\hline Vaccinium myrtillus L. & borówka czarna & $(\mathrm{Rk}),(\mathrm{Ru})$ & Bartkowiak 1970: 257 \\
\hline Vaccinium uliginosum L. & $\begin{array}{l}\text { borówka } \\
\text { bagienna }\end{array}$ & $(\mathrm{Rk}),(\mathrm{Ru})$ & $\begin{array}{r}\text { Turček 1961: 68, Bartkowiak } \\
\text { 1970: } 257\end{array}$ \\
\hline Vaccinium vitis-idaea $\mathrm{L}$. & $\begin{array}{l}\text { borówka } \\
\text { brusznica }\end{array}$ & $(\mathrm{Rk}),(\mathrm{Ro}),(\mathrm{Ru})$ & Bartkowiak 1970: 256 \\
\hline Veronica triphyllos L. & $\begin{array}{l}\text { przetacznik } \\
\text { trójlistkowy }\end{array}$ & (RzM), (Ch) & $\begin{array}{r}\text { Zcz, styczeń - luty; Oko } \\
\text { 1962a: } 26\end{array}$ \\
\hline Vicia L. & wyka & & Szczepkowski 1953: 88 \\
\hline Vicia sativa L. & wyka siewna & (Rk), (Rur) & $\begin{array}{r}\text { N; Oko, Wójtkowski 1960: } \\
317\end{array}$ \\
\hline Viola tricolor L. & fiołek trójbarwny & $(\mathrm{Ro}),(\mathrm{Ch}),(\mathrm{Ru})$ & $\begin{array}{r}\text { N; Oko, Wójtkowski 1960: } \\
317\end{array}$ \\
\hline Vitis vinifera $\mathrm{L}$. & $\begin{array}{l}\text { winorośl } \\
\text { właściwa }\end{array}$ & $\begin{array}{l}\text { (Rk), (Ro), } \\
\text { (Rur) }\end{array}$ & $\begin{array}{r}\text { Turček 1961: 71, Bartkowiak } \\
\text { 1970: } 255\end{array}$ \\
\hline Zea L. & kukurydza & $\begin{array}{l}\text { (Rk), (Ro), } \\
\text { (Rur) }\end{array}$ & $\begin{array}{r}\text { śruta; Pomarnacki 1955: 7, } \\
\text { Dzięciołowski 1961: 14, N; } \\
\text { Okarma 2008: } 331\end{array}$ \\
\hline \multicolumn{4}{|c|}{ Phasianus colchicus L., bażant szlachetny } \\
\hline Abies alba Mill. & jodła pospolita & $(\mathrm{Rk}),(\mathrm{Ro}),(\mathrm{Ru})$ & Turček 1961: 20 \\
\hline Achillea L. & krwawnik & & $\begin{array}{r}\text { k; Popławski 1951: 5, k, } \\
\text { posiekane; Knothe 1952: } \\
\text { 15,k, pisklęta; Konarski 1956: } \\
\text { 11, Walewski, Konarski } \\
\text { 1957: 121, 123, k, pisklęta, } \\
\text { posiekane; Staszek 1961: 17, } \\
\text { k, pisklęta; Konarski 1966: } \\
\text { 24, k, N; Dzięciołowski, } \\
\text { Kowalina 1971: 92, Behnke } \\
\text { 1995: 63, Gorazdowski, } \\
\text { Jabłoński 2002: 34, L; } \\
\text { Kruszewicz, Manelski 2007: } \\
46, \text { WT }\end{array}$ \\
\hline Achillea millefolium L. & $\begin{array}{l}\text { krwawnik } \\
\text { pospolity }\end{array}$ & $\begin{array}{l}(\mathrm{RzM}),(\mathrm{Rk}) \\
(\mathrm{Ro}),(\mathrm{Ru})\end{array}$ & Zcz, k, posiekane; KP, JW \\
\hline Acer L. & klon & & $\begin{array}{r}\text { Walewski, Konarski 1957: } \\
122\end{array}$ \\
\hline Acer pseudoplatanus L. & klon jawor & $(\mathrm{Rk}),(\mathrm{Ro}),(\mathrm{Ru})$ & Turček 1961: 21 \\
\hline
\end{tabular}




\begin{tabular}{|c|c|c|c|}
\hline Nazwa łacińska & Nazwa polska & Kategoria & Źródło \\
\hline Agrimonia L. & rzepik & & $\begin{array}{r}\text { Kruszewicz, Manelski 2007: } \\
84\end{array}$ \\
\hline Allium schoenoprasum L. & szczypior & & $\begin{array}{r}\text { Walewski, Konarski 1957: } \\
\text { 123, Gorazdowski, Jabłoński } \\
\text { 2002: } 34\end{array}$ \\
\hline $\begin{array}{l}\text { Alnus glutinosa (L.) } \\
\text { Gaertn. }\end{array}$ & olsza czarna & $(\mathrm{Rk}),(\mathrm{Ro}),(\mathrm{Ru})$ & N; Gacki 1974: 7 \\
\hline $\begin{array}{l}\text { Alnus viridis (Chaix) } \\
\text { DC. }\end{array}$ & olsza zielona & (Rk) & Turček 1961: 22 \\
\hline Alopecurus L. & wyczyniec & & L; Oko 1962: 17 \\
\hline Alopecurus pratensis L. & $\begin{array}{l}\text { wyczyniec } \\
\text { łąkowy }\end{array}$ & (Rk), (Rur) & L, kwiecień; Oko 1962: 19 \\
\hline Amaranthus L. & szarłat & & $\begin{array}{r}\text { N, O, kwiecień, sierpień; } \\
\text { Oko 1975: 135, } 150\end{array}$ \\
\hline $\begin{array}{l}\text { Amaranthus retroflexus } \\
\text { L. }\end{array}$ & szarłat szorstki & $(\mathrm{Ch}),(\mathrm{Ru})$ & $\begin{array}{r}\text { N, O, styczeń, luty, sierpień; } \\
\text { Oko 1975: 129, 131, } 150\end{array}$ \\
\hline Anagallis arvensis L. & kurzyślad polny & $(\mathrm{RzM}),(\mathrm{Ch})$ & $\begin{array}{r}\text { N, wrzesień; Oko 1962: 22, } \\
\text { Pę, N; Gacki 1974: 7, Zcz; } \\
\text { Oko, Gacki 1974: 161, 162, } \\
\text { sierpień, wrzesień; Oko } \\
\text { 1975: 151, } 155\end{array}$ \\
\hline $\begin{array}{l}\text { Anchusa arvensis (L.) } \\
\text { M.Bieb. }\end{array}$ & farbownik polny & $(\mathrm{RzM}),(\mathrm{Ru})$ & $\begin{array}{r}\text { N; Gacki 1974: 7, N; Oko, } \\
\text { Gacki 1974: 160, wrzesień; } \\
\text { Oko 1975: } 155\end{array}$ \\
\hline Anchusa officinalis L. & $\begin{array}{l}\text { farbownik } \\
\text { lekarski }\end{array}$ & $(\mathrm{Ru})$ & $\begin{array}{r}\text { N, wrzesień; Oko 1962: 22, } \\
\text { wrzesień; Oko 1975: } 155 \\
\end{array}$ \\
\hline Anthemis arvensis L. & rumian polny & $\begin{array}{l}(\mathrm{RzM}),(\mathrm{Ch}), \\
(\mathrm{Ru})\end{array}$ & N; Oko, Gacki 1974: 159 \\
\hline $\begin{array}{l}\text { Anthoxanthum } \\
\text { odoratum L. }\end{array}$ & tomka wonna & $\begin{array}{l}(\mathrm{RzM}),(\mathrm{Rk}) \\
(\mathrm{Ru})\end{array}$ & L, marzec; Oko 1962: 19 \\
\hline $\begin{array}{l}\text { Apera spica-venti (L.) } \\
\text { P.Beauv }\end{array}$ & miotła zbożowa & $\begin{array}{l}(\mathrm{RzM}),(\mathrm{Ch}) \\
(\mathrm{Ru})\end{array}$ & $\begin{array}{r}\text { L; Gacki 1974: 7, N, Zcz; } \\
\text { Oko, Gacki 1974: 159, 161, N, } \\
\text { O, lipiec, październik; Oko } \\
\text { 1975: 146, 159, L; Lempaszak } \\
\text { 1977: } 7\end{array}$ \\
\hline Apiaceae Lindl. & selerowate & & $\begin{array}{r}\text { Ko, Pę, marzec; Oko 1975: } \\
129\end{array}$ \\
\hline
\end{tabular}




\begin{tabular}{|c|c|c|c|}
\hline Nazwa łacińska & Nazwa polska & Kategoria & Źródło \\
\hline Apium graveolens $\mathrm{L}$. & seler zwyczajny & (Rur) & $\begin{array}{r}\text { Matuszewski, Morow 1994: } \\
34\end{array}$ \\
\hline Arctium lappa L. & łopian większy & $(\mathrm{Ch}),(\mathrm{Ru})$ & N; Oko, Gacki 1974: 159 \\
\hline Arenaria serpyllifolia L. & $\begin{array}{l}\text { piaskowiec } \\
\text { macierzankowy }\end{array}$ & (Ch) & $\begin{array}{r}\text { N, O, maj, czerwiec, sierpień; } \\
\text { Oko 1975: 138, 141, } 150\end{array}$ \\
\hline $\begin{array}{l}\text { Arrhenatherum elatius } \\
\text { (L.) P.Beauv. ex } \\
\text { J.Presl \& C.Presl. }\end{array}$ & rajgras wyniosły & $(\mathrm{Rk}),(\mathrm{Ru})$ & $\begin{array}{r}\mathrm{N} \text {; Oko 1962: 17, N, O, } \\
\text { październik; Oko 1975: } 159\end{array}$ \\
\hline Artemisia absinthium L. & bylica piołun & $(\mathrm{Ro}),(\mathrm{Ch}),(\mathrm{Ru})$ & Mróz 2003: 99 \\
\hline Artemisia vulgaris $\mathrm{L}$. & bylica pospolita & $(\mathrm{Ch}),(\mathrm{Ru})$ & $\begin{array}{r}\text { Gacki 1974: 7, Zcz; Oko, } \\
\text { Gacki 1974: } 162\end{array}$ \\
\hline Asteraceae Dum. & astrowate & & $\begin{array}{r}\text { N, czerwiec, lipiec, sierpień, } \\
\text { grudzień; Oko 1975: 141, } \\
142,146,151,165\end{array}$ \\
\hline Atriplex patula L. & łoboda rozłożysta & $\begin{array}{l}(\mathrm{RzM}),(\mathrm{Ch}) \\
(\mathrm{Ru})\end{array}$ & N; Dzięciołowski 1964: 15 \\
\hline Avena L. & owies & & $\begin{array}{r}\text { N; Cornau 1903: 150, Pęski } \\
\text { 1928: 19, plewy; Feil 1950: 20, } \\
\text { N; Walewski, Konarski 1957: } \\
\text { 40, N Sokołowski 1958: 146, } \\
\text { N, kwiecień - maj; Oko 1962: } \\
\text { 19, k; Konarski 1966: 20, N; } \\
\text { Dzięciołowski, Kowalina } \\
\text { 1971: 17, N; Sokołowski } \\
\text { 1972: 119, Gacki 1974: 7, } \\
\text { Cramp1980: 507, 508, k, N; } \\
\text { Skrzypek 1981a: 5, Behnke } \\
\text { 1995: 40, N; Mróz 2003: } 46\end{array}$ \\
\hline Avena sativa $\mathrm{L}$. & owies zwyczajny & $\begin{array}{l}\text { (Rk), (Ro), } \\
\text { (Rur), }\end{array}$ & $\begin{array}{r}\text { Glutz 1973: 364, N, Zcz; } \\
\text { Oko, Gacki 1974: 159, 161, } \\
\text { N, luty - kwiecień, czerwiec } \\
\text { - wrzesień, grudzień; Oko } \\
\text { 1975: 130, 133, 135, 141, 146, } \\
\text { 150, 154, 158, 161, 164, Łaz., } \\
\text { JW, } 2000 .\end{array}$ \\
\hline
\end{tabular}




\begin{tabular}{|c|c|c|c|}
\hline Nazwa łacińska & Nazwa polska & Kategoria & Źródło \\
\hline Berberis L. & berberys & & $\begin{array}{r}\text { O; Walewski, Konarski } \\
\text { 1957: 40, O; Dzięciołowski, } \\
\text { Kowalina 1971: 17,O; } \\
\text { Gorazdowski, Jabłoński } \\
\text { 2002: 33, 34, O; Mróz 2003: } \\
\text { 49, O; Kruszewicz, Manelski } \\
2007: 43,47 \\
\end{array}$ \\
\hline $\begin{array}{l}\text { Berberis aquifolium } \\
\text { Pursh }\end{array}$ & $\begin{array}{l}\text { mahonia } \\
\text { pospolita }\end{array}$ & (Ro), (Ru) & Turček 1961: 40 \\
\hline Beta L. & burak & & $\begin{array}{r}\text { Dembinok 1956: 11, } \\
\text { Sokołowski 1958: 146, } \\
\text { pokrojony; Kopijowska 1961: } \\
\text { 30, Sokołowski 1972: 119, Bk, } \\
\text { N; Gacki 1974: 7, Żołnierzak } \\
\text { 1991: 19, Kamieniarz 1999: }\end{array}$ \\
\hline Beta vulgaris L. & burak zwyczajny & (Rk), (Rur) & $\begin{array}{r}\text { Glutz 1973: 364, N, Ko; Oko, } \\
\text { Gacki 1974: 159, 161, K, N, } \\
\text { O, Pę, luty, marzec sierpień } \\
\text { - grudzień; Oko 1975: 131, } \\
\text { 133, 151, 156, 158, 161, 162, } \\
164\end{array}$ \\
\hline $\begin{array}{l}\text { Beta vulgaris subsp. } \\
\text { vulgaris }\end{array}$ & burak pastewny & (Rk), (Rur) & $\begin{array}{r}\text { Feil1 950: 20, Walewski, } \\
\text { Konarski 1957: 41, L; } \\
\text { Dzięciołowski, Kowalina } \\
\text { 1971: 17, Łukasik 1996: 234, } \\
\text { Gorazdowski, Jabłoński } \\
\text { 2002: 33, Bk; Mróz 2003: 49, } \\
\text { Kruszewicz, Manelski 2007: } \\
\text { 84, N; Okarma 2008: } 331\end{array}$ \\
\hline
\end{tabular}




\begin{tabular}{|c|c|c|c|}
\hline Nazwa łacińska & Nazwa polska & Kategoria & Źródło \\
\hline $\begin{array}{l}\text { Beta vulgaris subsp. } \\
\text { vulgaris convar. } \\
\text { vulgaris var. altissima }\end{array}$ & burak cukrowy & (Rk), (Rur) & $\begin{array}{r}\text { Feil 1950: 20, Stokowski } \\
\text { 1952: 8, suche wywłoki; } \\
\text { Dembinok 1956: 11, } \\
\text { Walewski, Konarski 1957: 41, } \\
\text { L; Dzięciołowski, Kowalina } \\
\text { 1971: 17, Łukasik 1996: 234, } \\
\text { Gorazdowski, Jabłoński } \\
\text { 2002: 33, Bk; Mróz 2003: 49, } \\
\text { Kruszewicz, Manelski 2007: } \\
\text { 84, N; Okarma 2008: } 331\end{array}$ \\
\hline Betula L. & brzoza & & $\begin{array}{r}\text { L, Pę; Kruszewicz, Manelski } \\
\text { 2007: } 46\end{array}$ \\
\hline Betula nigra L. & $\begin{array}{l}\text { brzoza } \\
\text { nadrzeczna }\end{array}$ & & Turček 1961: 24 \\
\hline Brassicaceae Burnett & kapustowate & & $\begin{array}{r}\text { kwiecień, październik, } \\
\text { grudzień; Oko 1975: 136, } \\
159,164\end{array}$ \\
\hline Brassica L. & kapusta & & $\begin{array}{r}\text { Pęski 1928: 19, L; Walewski, } \\
\text { Konarski 1957: 121, } \\
\text { Sokołowski 1958: 146, } \\
\text { Sokołowski 1972: 119, } \\
\text { k; Skrzypek 1981: 10, } \\
\text { Żołnierzak 1991: 19, Behnke } \\
\text { 1995: } 38\end{array}$ \\
\hline Brassica napus L. & rzepak & $\begin{array}{l}\text { (Rk), }(\mathrm{Ch}), \\
\text { (Rur) }\end{array}$ & $\begin{array}{r}\text { K, Pa, maj; Oko 1962: 20, } \\
\text { Dzięciołowski, Kowalina } \\
\text { 1971: 47, Bk; Gacki 1974: } \\
\text { 7, N, Ko, Zcz; Oko, Gacki } \\
\text { 1974: 160, 161, Ko, styczeń - } \\
\text { kwiecień, czerwiec, Ko, Pę, } \\
\text { maj, listopad, grudzień, Oko } \\
\text { 1975: 129, 132, 134, 136, 139, } \\
\text { 142, 162, 164, Bk; Lempaszak } \\
\text { 1977: 7, Cramp 1980: 507, } \\
\text { śruta; Mróz 2003: } 96\end{array}$ \\
\hline $\begin{array}{l}\text { Brassica napus L. var. } \\
\text { napobrassica }\end{array}$ & brukiew & (Rk), (Rur) & $\begin{array}{r}\text { Dembinok 1956: 11, N; } \\
\text { Dzięciołowski, Kowalina } \\
1971: 50,56\end{array}$ \\
\hline $\begin{array}{l}\text { Brassica oleracea var. } \\
\text { botrytis }\end{array}$ & kalafior & (Rk), (Rur) & Matuszewski, Morow 1994: \\
\hline
\end{tabular}




\begin{tabular}{|c|c|c|c|}
\hline Nazwa łacińska & Nazwa polska & Kategoria & Źródło \\
\hline $\begin{array}{l}\text { Brassica oleracea var. } \\
\text { capitala }\end{array}$ & kapusta biała & (Rk), (Rur) & $\begin{array}{r}\text { Kruszewicz, Manelski 2007: } \\
43,84\end{array}$ \\
\hline $\begin{array}{l}\text { Brassica oleracea var. } \\
\text { medullosa }\end{array}$ & kapusta pastewna & (Rk), (Rur) & $\begin{array}{r}\text { k; Walewski, Konarski 1957: } \\
\text { 153, pokrojona; Kopijowska } \\
\text { 1961: 30, Dzięciołowski, } \\
\text { Kowalina 1971: 46, L; } \\
\text { Bochniarzowa 1974: 7, } \\
\text { Pielowski 1984: 13, Łogin } \\
\text { 1995: 12, Kamieniarz 1999: } \\
\text { 15, N; Kruszewicz, Manelski } \\
\text { 2007: 83, Chojnowski 2011: } \\
58\end{array}$ \\
\hline $\begin{array}{l}\text { Brassica oleracea L. var. } \\
\text { sabellica L. }\end{array}$ & jarmuż & (Rk), (Rur) & $\begin{array}{r}\text { Dzięciołowski, Kowalina } \\
\text { 1971: 46, Łogin 1995: 12, } \\
\text { Matuszewski, Morow 1994: } \\
\text { 34, Kamieniarz 1999: } 15\end{array}$ \\
\hline $\begin{array}{l}\text { Brassica rapa subsp. } \\
\text { Rapa }\end{array}$ & $\begin{array}{l}\text { rzepa } \\
\text { ścierniskowa }\end{array}$ & (Rk), (Rur) & $\begin{array}{r}\text { Gorazdowski, Jabłoński } \\
\text { 2002: 34, Kruszewicz, } \\
\text { Manelski 2007: } 84\end{array}$ \\
\hline $\begin{array}{l}\text { Brassica rapa subsp. } \\
\text { Pekinensis }\end{array}$ & kapusta pekińska & (Rk), (Rur) & $\begin{array}{r}\text { Gorazdowski, Jabłoński } \\
2002: 34\end{array}$ \\
\hline $\begin{array}{l}\text { Brassicaceae Burnett, } \\
\text { Cruciferae Juss. }\end{array}$ & kapustowate & & N; Oko, Gacki 1974: 160 \\
\hline Bromus hordeaceus L. & stokłosa miękka & (Ch) & $\begin{array}{r}\text { L, marzec, kwiecień, } \\
\text { czerwiec; Oko 1962: 19, 20, } \\
\text { N, O, kwiecień; Oko 1975: } \\
136\end{array}$ \\
\hline Bromus inermis Leyss. & stokłosa bezostna & $(\mathrm{Ch})$ & N, O, maj; Oko 1975: 138 \\
\hline $\begin{array}{l}\text { Camelina sativa (L.) } \\
\text { Crantz }\end{array}$ & lnicznik siewny & $\begin{array}{l}(\mathrm{RzM}),(\mathrm{Rz}) \\
(\mathrm{Ch}),(\mathrm{Ru})\end{array}$ & $\begin{array}{r}\text { N; Gacki 1974: 7, Zcz; Oko, } \\
\text { Gacki 1974: } 161\end{array}$ \\
\hline Cannabis L. & konopia & & $\begin{array}{r}\text { Cornau 1903: 193, k; } \\
\text { Walewski, Konarski } \\
\text { 1957: 154, N; Walewski, } \\
\text { Konarski 1957: 72, } \\
\text { 126, N; Dzięciołowski, } \\
\text { Kowalina 1971: 50, 56, N; } \\
\text { Gorazdowski, Jabłoński } \\
\text { 2002: } 34\end{array}$ \\
\hline
\end{tabular}




\begin{tabular}{|c|c|c|c|}
\hline Nazwa łacińska & Nazwa polska & Kategoria & Źródło \\
\hline Cannabis sativa $\mathrm{L}$. & konopia siewna & $(\mathrm{Ch}),(\mathrm{Ru})$ & N; Oko, Gacki 1974: 160 \\
\hline Caprifoliaceae Juss. & przewiertniowate & & $\begin{array}{r}\text { sierpień, listopad; Oko 1975: } \\
150,161\end{array}$ \\
\hline Carex $\mathrm{L}$. & turzyca & & $\begin{array}{r}\text { Szederjei 1958: 13, K, Pa, } \\
\text { maj; Oko 1962: } 20\end{array}$ \\
\hline Carpinus L. & grab & & N; Walewski, Konarski 1957: \\
\hline Carpinus betulus L. & grab pospolity & (Rk), (Ro), (Ru) & Turček 1961: 25 \\
\hline Caryophyllaceae Juss. & goździkowate & & $\begin{array}{r}\text { N, O, kwiecień, czerwiec, } \\
\text { sierpień, wrzesień, Ko, Pę, } \\
\text { maj; Oko 1975: 135, 139, } 143, \\
150,156\end{array}$ \\
\hline $\begin{array}{l}\text { Catalpa speciosa } \\
\text { (Warder ex Barney) } \\
\text { Warder ex Engelm }\end{array}$ & $\begin{array}{l}\text { surmia } \\
\text { wielokwiatowa }\end{array}$ & (Rk), (Ro), (Ru) & Turček 1961: 25 \\
\hline Celtis australis L. & $\begin{array}{l}\text { wiązowiec } \\
\text { południowy }\end{array}$ & $(\mathrm{Rk}),(\mathrm{Ro}),(\mathrm{Ru})$ & Turček 1961: 25 \\
\hline Centaurea L. & chaber & & k; Walewski, Konarski 1957: \\
\hline Centaurea cyanus L. & chaber bławatek & $\begin{array}{l}\text { (RzM), (Rk), } \\
(\mathrm{Ro}),(\mathrm{Ch}),(\mathrm{Ru})\end{array}$ & $\begin{array}{r}\text { N, czerwiec - wrzesień; Oko } \\
\text { 1962: 17, 20, 22, N; Gacki } \\
\text { 1974: 7, N; Oko, Gacki 1974: } \\
\text { 159, N, O styczeń - marzec, } \\
\text { maj, sierpień, październik } \\
\text { - grudzień; Oko 1975: 129, } \\
\text { 131, 133, 138, 151, 159, 162, } \\
\text { 165, N; Lempaszak 1977: } 7\end{array}$ \\
\hline Cerasus Mill. & wiśnia & & $\begin{array}{r}\text { O; Walewski, Konarski } \\
\text { 1957: 40, 122, Dzięciołowski, } \\
\text { Kowalina 1971: 16, O; Mróz } \\
\text { 2003: } 49\end{array}$ \\
\hline $\begin{array}{l}\text { Cerasus fruticosa (Pall.) } \\
\text { Woronow }\end{array}$ & wiśnia karłowata & $(\mathrm{Rz}),(\mathrm{Ro}),(\mathrm{Ru})$ & Turček 1961: 50 \\
\hline $\begin{array}{l}\text { Cerasus mahaleb (L.) } \\
\text { Mill }\end{array}$ & wiśnia wonna & $(\mathrm{Ro}),(\mathrm{Ru})$ & Turček 1961: 50 \\
\hline Cerastium L. & rogownica & & $\begin{array}{r}\text { sierpień, wrzesień; Oko } \\
\text { 1975: 150, } 155\end{array}$ \\
\hline
\end{tabular}




\begin{tabular}{|c|c|c|c|}
\hline Nazwa łacińska & Nazwa polska & Kategoria & Źródło \\
\hline Cerastium arvense $\mathrm{L}$. & rogownica polna & (Ch) & $\begin{array}{r}\text { lipiec, wrzesień; Oko 1975: } \\
146,154\end{array}$ \\
\hline $\begin{array}{l}\text { Cerastium glomeratum } \\
\text { Thuill. }\end{array}$ & $\begin{array}{l}\text { rogownica } \\
\text { pospolita }\end{array}$ & (Ch) & $\begin{array}{r}\text { N, O, maj, czerwiec, sierpień, } \\
\text { październik; Oko 1975: 138, } \\
141,150,158\end{array}$ \\
\hline $\begin{array}{l}\text { Cerastium } \\
\text { semidecandrum L. } 160\end{array}$ & $\begin{array}{l}\text { rogownica } \\
\text { pięciopręcikowa }\end{array}$ & (Ch) & $\begin{array}{r}\text { N, wrzesień; Oko 1962: 22, } \\
\text { luty, sierpień; Oko 1975: 131, } \\
150\end{array}$ \\
\hline Chenopodium L. & komosa & & $\begin{array}{r}\text { L, Pę, maj, sierpień; Oko } \\
\text { 1962: 19, 22, Ko, N, O, Pę, } \\
\text { luty - kwiecień, czerwiec } \\
\text { - listopad; Oko 1975: 131, } \\
\text { 133, 135, 142, 146, 151, 154, } \\
\text { 156, 159, 161, Gorazdowski, } \\
\text { Jabłoński 2002: } 34\end{array}$ \\
\hline Chenopodium album $\mathrm{L}$. & komosa biała & $(\mathrm{Rk}),(\mathrm{Ch}),(\mathrm{Ru})$ & $\begin{array}{r}\text { Szederjei 1958: 13, N, } \\
\text { marzec, wrzesień; Oko 1962: } \\
\text { 19, 22, Glutz 1973: 363, N; } \\
\text { Oko, Gacki 1974: 159, N; } \\
\text { Lempaszak 1977: 7, Cramp } \\
\text { 1980: 507, Kruszewicz, } \\
\text { Manelski 2007: 46, } 84\end{array}$ \\
\hline $\begin{array}{l}\text { Chenopodium } \\
\text { polyspermum L. }\end{array}$ & $\begin{array}{l}\text { komosa } \\
\text { wielonasienna }\end{array}$ & (RzM), (Ch) & $\begin{array}{r}\text { N, marzec; Oko 1962: 19, N, } \\
\text { O, wrzesień; Oko 1975: } 154\end{array}$ \\
\hline Cichorium L. & cykoria & & $\begin{array}{r}\text { Walewski, Konarski 1957: } \\
\text { 121, k, pisklęta, L; Sikorski } \\
\text { 1965: 6, Gorazdowski, } \\
\text { Jabłoński 2002: } 34\end{array}$ \\
\hline Convolvulus arvensis $\mathrm{L}$. & powój polny & (RzM), (Rk) & $\begin{array}{r}\text { Szederjei 1958: 13, N; Gacki } \\
1974: 7\end{array}$ \\
\hline Cornus alternifolia L.f & dereń skrętolistny & & Turček 1961: 26 \\
\hline Cornus mas L. & dereń jadalny & $(\mathrm{Ro}),(\mathrm{Ru})$ & Turček 1961: 26 \\
\hline Cornus sanguinea L. & dereń świdwa & $(\mathrm{Rk}),(\mathrm{Ro}),(\mathrm{Ru})$ & Bartkowiak 1970: 256 \\
\hline $\begin{array}{l}\text { Cornus sericea subsp. } \\
\text { sericea }\end{array}$ & dereń rozłogowy & (Ro) & Turček 1961: 27 \\
\hline $\begin{array}{l}\text { Corydalis solida (L.) } \\
\text { Clairv. }\end{array}$ & kokorycz pełna & $\begin{array}{l}(\mathrm{RzM}),(\mathrm{Rz}) \\
(\mathrm{Ro})\end{array}$ & $\begin{array}{r}\text { Bk; Gacki 1974: 7, Zcz; Oko, } \\
\text { Gacki 1974: } 161\end{array}$ \\
\hline Corylus L. & leszczyna & & N; Cornau 1903: 30 \\
\hline
\end{tabular}




\begin{tabular}{|c|c|c|c|}
\hline Nazwa łacińska & Nazwa polska & Kategoria & Źródło \\
\hline Corylus avellana L. & $\begin{array}{l}\text { leszczyna } \\
\text { pospolita }\end{array}$ & $(\mathrm{Rk}),(\mathrm{Ro}),(\mathrm{Ru})$ & $\begin{array}{r}\text { N, O, marzec, grudzień; Oko } \\
\text { 1975: 133, 164, Cramp 1980: } \\
507\end{array}$ \\
\hline Cotoneaster Medik & irga & & $\begin{array}{r}\text { O; Dzięciołowski 1964: 15, } \\
\text { Kruszewicz, Manelski 2007: }\end{array}$ \\
\hline Crataegus L. & głóg & & $\begin{array}{r}\text { Dembinok 1956: 11, N; } \\
\text { Walewski, Konarski } \\
\text { 1957: 122, Dzięciołowski, } \\
\text { Kowalina 1971: 16, Glutz } \\
\text { 1973: 363, N; Okarma 2008: } \\
331\end{array}$ \\
\hline $\begin{array}{l}\text { Crataegus monogyna } \\
\text { Jacq. }\end{array}$ & $\begin{array}{l}\text { głóg } \\
\text { jednoszyjkowy }\end{array}$ & $(\mathrm{Rk}),(\mathrm{Ro}),(\mathrm{Ru})$ & $\begin{array}{r}\text { Bartkowiak 1970: 250, } \\
\text { N; Gacki 1974: 7, luty, } \\
\text { październik; Oko 1975: 131, } \\
\text { 158, Cramp 1980: } 507\end{array}$ \\
\hline $\begin{array}{l}\text { Crataegus prunifolia } \\
\text { (Poir.) Pers }\end{array}$ & głóg śliwolistny & $(\mathrm{Rk}),(\mathrm{Ro}),(\mathrm{Ru})$ & O; Dzięciołowski 1964: 15 \\
\hline Cucumis L. & ogórek & & N; Gacki 1974: 7 \\
\hline Cucumis sativus L. & ogórek siewny & $(\mathrm{Ru}),(\mathrm{Rur})$ & październik; Oko 1975: 159 \\
\hline $\begin{array}{l}\text { Cytisus scoparius (L.) } \\
\text { Link }\end{array}$ & $\begin{array}{l}\text { żarnowiec } \\
\text { miotlasty }\end{array}$ & $(\mathrm{Rk}),(\mathrm{Ro}),(\mathrm{Ru})$ & N; Jeleniak 2002: 21 \\
\hline Dactylis glomerata L. & $\begin{array}{l}\text { kupkówka } \\
\text { pospolita }\end{array}$ & $(\mathrm{Rk}),(\mathrm{Ru})$ & $\begin{array}{r}\text { N, O, kwiecień - czerwiec; } \\
\text { Oko 1975: 136, 138, } 142\end{array}$ \\
\hline $\begin{array}{l}\text { Digitaria ischaemum } \\
\text { (Schreb.) Muhl. }\end{array}$ & $\begin{array}{l}\text { palusznik } \\
\text { nitkowaty }\end{array}$ & $\begin{array}{l}(\mathrm{RzM}),(\mathrm{Rz}), \\
(\mathrm{Ro}),(\mathrm{Ru})\end{array}$ & N; Oko, Gacki 1974: 159 \\
\hline Daucus L. & marchew & & $\begin{array}{r}\text { Walewski, Konarski 1957: } \\
\text { 41, Fedorowski 1961: 15, } \\
\text { pokrojone; Kopijowska 1961: } \\
\text { 30, Dzięciołowski, Kowalina } \\
\text { 1971: 17, 46, k; Skrzypek } \\
\text { 1981: 10, tarta; Gorazdowski, } \\
\text { Jabłoński 2002: 33, tarta; } \\
\text { Mróz 2003: 100, siekana; } \\
\text { Kruszewicz, Manelski 2007: }\end{array}$ \\
\hline
\end{tabular}




\begin{tabular}{|c|c|c|c|}
\hline Nazwa łacińska & Nazwa polska & Kategoria & Źródło \\
\hline Daucus carota $\mathrm{L}$. & $\begin{array}{l}\text { marchew } \\
\text { zwyczajna }\end{array}$ & $\begin{array}{l}\text { (Rk), (Rur), } \\
(\mathrm{Ru})\end{array}$ & $\begin{array}{r}\text { Feil1 950: 20, Stokowski } \\
\text { 1952: 8, Dembinok 1956: } \\
\text { 11, Sokołowski 1958: } \\
\text { 146, Sokołowski 1972: } \\
\text { 119, Łukasik 1996: 234, } \\
\text { Kamieniarz 1999: } 15\end{array}$ \\
\hline Daphne mezereum L. & $\begin{array}{l}\text { wawrzynek } \\
\text { wilczełyko }\end{array}$ & $(\mathrm{Rz}),(\mathrm{Ro}),(\mathrm{Ru})$ & $\begin{array}{r}\text { O; Sokołowski 1958: 146, } \\
\text { Turček 1961: 29, Bartkowiak } \\
\text { 1970: 255, O; Sokołowski } \\
\text { 1972: 119, Glutz 1973: } 362\end{array}$ \\
\hline $\begin{array}{l}\text { Echinochloa crus-galli } \\
\text { (L.) P.Beauv. }\end{array}$ & $\begin{array}{l}\text { chwastnica } \\
\text { jednostronna }\end{array}$ & (RzM), (Ch) & $\begin{array}{r}\text { N, Pę, marzec, czerwiec, } \\
\text { sierpień, wrzesień; Oko } \\
\text { 1962: 19, 20, 22, N; Gacki } \\
\text { 1974: 7, N; Oko, Gacki 1974: } \\
\text { 159, N, O, marzec - } \\
\text { czerwiec, sierpień - } \\
\text { październik; Oko 1975: 133, } \\
\text { 135, 138, 142, 151, 155, } 158\end{array}$ \\
\hline Elaeagnus L. & rokitnik & & $\begin{array}{r}\text { Walewski, Konarski 1957: } \\
\text { 122, Kruszewicz, Manelski } \\
\text { 2007: } 47\end{array}$ \\
\hline Elaeagnus angustifolia L. & $\begin{array}{l}\text { oliwnik } \\
\text { wąskolistny }\end{array}$ & (Ro), (Ru) & Cramp 1980: 507 \\
\hline $\begin{array}{l}\text { Elaeagnus rhamnoides } \\
\text { (L.) A.Nelson }\end{array}$ & $\begin{array}{l}\text { rokitnik } \\
\text { zwyczajny }\end{array}$ & $\begin{array}{l}(\mathrm{Rz}),(\mathrm{Rk}),(\mathrm{Ro}), \\
(\mathrm{Ru})\end{array}$ & $\begin{array}{r}\text { O; Walewski, Konarski 1957: } \\
\text { 67, Bartkowiak 1970: 255, } \\
\text { Urs., JW, 1994, Kacz., JW } \\
2002 \text { - } 2007\end{array}$ \\
\hline $\begin{array}{l}\text { Elymus repens (L.) } \\
\text { Gould } 139\end{array}$ & perz właściwy & $(\mathrm{Ch}),(\mathrm{Ru})$ & $\begin{array}{r}\text { L, kwiecień; Oko 1962: 19, } \\
\text { N, Zcz; Oko, Gacki 1974: } \\
\text { 159,161, Ko, Pę, styczeń, } \\
\text { kwiecień, październik, } \\
\text { grudzień; Oko 1975: 129, } \\
\text { 132, 136, 159, 166, Bk; } \\
\text { Lempaszak 1977: } 7\end{array}$ \\
\hline $\begin{array}{l}\text { Empetrum } \\
\text { hermaphroditum } \\
\text { Hagerup }\end{array}$ & $\begin{array}{l}\text { barzyna } \\
\text { obupłciowa }\end{array}$ & & Turček 1961: 30 \\
\hline
\end{tabular}




\begin{tabular}{|c|c|c|c|}
\hline Nazwa łacińska & Nazwa polska & Kategoria & Źródło \\
\hline Empetrum nigrum L. & bażyna czarna & $(\mathrm{Rz}),(\mathrm{Rk}),(\mathrm{Ro})$ & Bartkowiak 1970: 254 \\
\hline Equisetum L. & skrzyp & & $\begin{array}{r}\text { N, O, kwiecień, Ko, Pę, } \\
\text { grudzień; Oko 1975: 135, } 164\end{array}$ \\
\hline Equisetum arvense L. & skrzyp polny & $\begin{array}{l}(\mathrm{RzM}),(\mathrm{Ch}) \\
(\mathrm{Ru})\end{array}$ & $\begin{array}{r}\text { Ko, Pę, luty, N, O, kwiecień; } \\
\text { Oko 1975: 131, 135, Pę; } \\
\text { Lempaszak 1977: } 7\end{array}$ \\
\hline Equisetum fluviatile L. & skrzyp bagienny & & $\begin{array}{r}\text { Ko, Pę, grudzień; Oko 1975: } \\
165\end{array}$ \\
\hline Euonymus L. & trzmielina & & $\begin{array}{r}\text { O; Sokołowski 1958: 146, O; } \\
\text { Sokołowski 1972: } 119\end{array}$ \\
\hline Euonymus europaeus L. & $\begin{array}{l}\text { trzmielina } \\
\text { pospolita }\end{array}$ & $(\mathrm{Rk}),(\mathrm{Ro}),(\mathrm{Ru})$ & Turček 1961: 31, O, JW, 1995 \\
\hline $\begin{array}{l}\text { Euphorbia amygdaloides } \\
\text { L. }\end{array}$ & $\begin{array}{l}\text { wilczomlecz } \\
\text { migdałolistny }\end{array}$ & (RzM), (Ch) & L; Dzięciołowski 1964: 15 \\
\hline Fabaceae Lindl. & bobowate & & $\begin{array}{r}\mathrm{N}, \text { O, luty, kwiecień, } \\
\text { czerwiec - sierpień, } \\
\text { październik - grudzień; Oko } \\
1975: \text { 131, 132, 136, } 143, \\
145,151,152,159,161,164, \\
165\end{array}$ \\
\hline Fagopyrum Mill. & gryka & & $\begin{array}{r}\text { N; Cornau 1903: 147, N; } \\
\text { Walewski, Konarski 1957: } \\
\text { 40, N; Sokołowski 1958: } \\
\text { 146, Nowak 1961: 125, N; } \\
\text { Dzięciołowski, Kowalina } \\
\text { 1971: 17, N; Sokołowski } \\
\text { 1972: 119, Behnke 1995: } 37, \\
\text { N; Mróz 2003: } 49\end{array}$ \\
\hline Fagus L. & buk & & $\begin{array}{r}\text { N; Pęski 1928: 19, N; } \\
\text { Walewski, Konarski 1957: } \\
\text { 67, 122, N; Sokołowski } \\
\text { 1958: 146, N; Sokołowski } \\
\text { 1972: 119, O; Gorazdowski, } \\
\text { Jabłoński 2002: } 33\end{array}$ \\
\hline Fagus sylvatica L. & buk zwyczajny & $(\mathrm{Rk}),(\mathrm{Ro}),(\mathrm{Ru})$ & $\begin{array}{r}\text { Turček 1961: 32, Bartkowiak } \\
\text { 1970: 249, N, O, grudzień; } \\
\text { Oko 1975: 164, N, JW, } 1995\end{array}$ \\
\hline
\end{tabular}




\begin{tabular}{|c|c|c|c|}
\hline Nazwa łacińska & Nazwa polska & Kategoria & Źródło \\
\hline $\begin{array}{l}\text { Festuca pratensis } \\
\text { Huds. }\end{array}$ & kostrzewa łąkowa & $(\mathrm{Ru})$ & $\begin{array}{r}\text { N, L; Oko 1962: 17, N; Oko, } \\
\text { Gacki 1974: 159, czerwiec; } \\
\text { Oko 1975: } 142\end{array}$ \\
\hline Ficaria verna Huds. & $\begin{array}{l}\text { ziarnopłon } \\
\text { wiosenny }\end{array}$ & (Rk), (Ro), (Ru) & $\begin{array}{r}\text { Bk; Walewski, Konarski } \\
\text { 1957: 40, Bk, maj; Oko 1962: } \\
\text { 20, Ko; Dzięciołowski, } \\
\text { Kowalina 1971: 17, Glutz } \\
\text { 1973: 363, Bk, N, Pę; Gacki } \\
\text { 1974: 7, Bk; Oko, Gacki } \\
\text { 1974: 161, Ko, Pę, maj; Bk, } \\
\text { czerwiec; Oko 1975: 139, 142, } \\
\text { Bk; Mróz 2003: } 49\end{array}$ \\
\hline Fragaria L. & poziomka & & $\begin{array}{r}\text { O; Walewski, Konarski 1957: } \\
\text { 40, Nowak 1961: 125, O; } \\
\text { Mróz 2003: 49, Kruszewicz, } \\
\text { Manelski 2007: } 47\end{array}$ \\
\hline $\begin{array}{l}\text { Fragaria } \times \text { ananassa } \\
(\text { Weston) Duchesne }\end{array}$ & truskawka & & $\begin{array}{r}\text { Kruszewicz, Manelski 2007: } \\
47\end{array}$ \\
\hline Frangula dodonei Ard. & $\begin{array}{l}\text { kruszyna } \\
\text { pospolita }\end{array}$ & $\begin{array}{l}\text { (RzM), (Rz), } \\
(\mathrm{Rk}),(\mathrm{Ro}),(\mathrm{Ru})\end{array}$ & $\begin{array}{r}\text { O; Walewski, Konarski 1957: } \\
\text { 67, Turček 1961: 53, N; Gacki } \\
1974: 7\end{array}$ \\
\hline Fraxinus L. & jesion & & $\begin{array}{l}\text { N; Walewski, Konarski 1957: } \\
\text { 67, N; Dzięciołowski 1964: } 15\end{array}$ \\
\hline Fumaria officinalis L. & $\begin{array}{l}\text { dymnica } \\
\text { pospolita }\end{array}$ & $\begin{array}{l}(\mathrm{RzM}),(\mathrm{Ch}), \\
(\mathrm{Ru})\end{array}$ & Glutz 1973: 363 \\
\hline Galeopsis L. & poziewnik & & $\begin{array}{r}\text { Cramp 1980: 507, N, O, } \\
\text { marzec; Oko 1975: } 133\end{array}$ \\
\hline Galeopsis tetrahit L. & $\begin{array}{l}\text { poziewnik } \\
\text { szorstki }\end{array}$ & $\begin{array}{l}(\mathrm{RzM}),(\mathrm{Ch}) \\
(\mathrm{Ru})\end{array}$ & $\begin{array}{r}\text { Glutz 1973: 363, N, O, } \\
\text { marzec; Oko 1975: } 133\end{array}$ \\
\hline Galium aparine $\mathrm{L}$. & przytulia czepna & $(\mathrm{Ch})$ & $\begin{array}{r}\text { N; Gacki 1974: 7, N; } \\
\text { Oko, Gacki 1974: 160, N; } \\
\text { Lempaszak 1977: } 7\end{array}$ \\
\hline Geum rivale $\mathrm{L}$. & kuklik zwisły & $(\mathrm{Rk}),(\mathrm{Ru})$ & Glutz 1973: 364 \\
\hline Gleditsia triacanthos L. & $\begin{array}{l}\text { glediczja } \\
\text { trójcierniowa }\end{array}$ & $(\mathrm{Ro}),(\mathrm{Ru})$ & Turček 1961: 33 \\
\hline Glycine Willd. & soja & & $\begin{array}{r}\text { śruta; Mróz 2003: 96, N; } \\
\text { Kruszewicz, Manelski 2007: } \\
44\end{array}$ \\
\hline
\end{tabular}




\begin{tabular}{|c|c|c|c|}
\hline Nazwa łacińska & Nazwa polska & Kategoria & Źródło \\
\hline Helianthus L. & słonecznik & & $\begin{array}{r}\text { N; Stokowski 1952: 8, } \\
\text { Dembinok 1956: 11, N; } \\
\text { Walewski, Konarski 1957: 72, } \\
\text { N; Dzięciołowski, Kowalina } \\
\text { 1971: 56, Gorazdowski, } \\
\text { Jabłoński 2002: 33, N; } \\
\text { Kruszewicz, Manelski 2007: } \\
44,83\end{array}$ \\
\hline Helianthus annuus L. & $\begin{array}{l}\text { słonecznik } \\
\text { zwyczajny }\end{array}$ & $\begin{array}{l}\text { (Rk), (Ro), } \\
\text { (Rur) }\end{array}$ & wrzesień; Oko 1975: 155 \\
\hline Helianthus tuberosus L. & $\begin{array}{l}\text { słonecznik } \\
\text { bulwiasty }\end{array}$ & $(\mathrm{Rk}),(\mathrm{Ro}),(\mathrm{Ru})$ & $\begin{array}{r}\text { N; Feil 1950: 20, Dembinok } \\
\text { 1956: 11, Bk, L; Walewski, } \\
\text { Konarski 1957: 41, Buksiński } \\
\text { 1958: 42, Kaj 1961: 32, } \\
\text { Ortwein 1964: 15, Bk, L; } \\
\text { Dzięciołowski, Kowalina } \\
\text { 1971: 17, Pilarczyk 1987: } \\
\text { 28, Behnke 1995: 37, Bk; } \\
\text { Gorazdowski, Jabłoński } \\
\text { 2002: 33, Bk, L, Pę; Mróz } \\
\text { 2003: 49, Bk; Kruszewicz, } \\
\text { Manelski 2007: } 84\end{array}$ \\
\hline Hordeum L. & jęczmień & & $\begin{array}{r}\text { N; Cornau 1903: 150, Pęski } \\
\text { 1928: 19, Feil 1950: 20, } \\
\text { Dembinok 1956: 11, N; } \\
\text { Walewski, Konarski 1957: } \\
\text { 40, N; Sokołowski 1958: 146, } \\
\text { N, kwiecień, maj, lipiec; Oko } \\
\text { 1962: 17, 19, 22, k; Sikorski } \\
\text { 1962: 7, N; Dzięciołowski, } \\
\text { Kowalina 1971: 17, N; } \\
\text { Sokołowski 1972: 119, Glutz } \\
\text { 1973: 364, Gacki 1974: 7, } \\
\text { N; Lempaszak 1977: 7, } \\
\text { Cramp 1980: 507, 508, N; } \\
\text { Gorazdowski, Jabłoński } \\
\text { 2002: 33, 34, N; Okarma } \\
\text { 2008: } 331\end{array}$ \\
\hline
\end{tabular}




\begin{tabular}{|c|c|c|c|}
\hline Nazwa łacińska & Nazwa polska & Kategoria & Źródło \\
\hline Hordeum vulgare L. & $\begin{array}{l}\text { jęczmień } \\
\text { zwyczajny }\end{array}$ & (Rk), (Rur) & $\begin{array}{r}\text { N, Zcz; Oko, Gacki1974: } \\
159,161, \text { Ko, Pę; styczeń, N, } \\
\text { luty - grudzień; Oko 1975: } \\
129,130,132,133,135,136 \\
138,141,145,150,154,158 \\
161,164\end{array}$ \\
\hline Ilex aquifolium $\mathrm{L}$. & $\begin{array}{l}\text { ostrokrzew } \\
\text { kolczasty }\end{array}$ & $(\mathrm{Ro}),(\mathrm{Ru})$ & Turček 1961: 35 \\
\hline Juglans L. & orzech & & $\begin{array}{r}\text { N, pokruszone; Kruszewicz, } \\
\text { Manelski 2007: 44, } 47\end{array}$ \\
\hline Juniperus L. & jałowiec & & Dembinok 1956: 11 \\
\hline Juniperus communis L. & jałowiec pospolity & $(\mathrm{Rk}),(\mathrm{Ro}),(\mathrm{Ru})$ & $\begin{array}{r}\text { Turček 1961: 36, Bartkowiak } \\
1970: 248\end{array}$ \\
\hline Juniperus virginiana $\mathrm{L}$. & $\begin{array}{l}\text { jałowiec } \\
\text { wirginijski }\end{array}$ & $(\mathrm{Ro}),(\mathrm{Ru})$ & Bartkowiak 1970: 248 \\
\hline $\begin{array}{l}\text { Laburnum anagyroides } \\
\text { Medik. }\end{array}$ & $\begin{array}{l}\text { złotokap } \\
\text { zwyczajny }\end{array}$ & $(\mathrm{Ro}),(\mathrm{Ru}),(\mathrm{Ro})$ & Turček 1961: 37 \\
\hline Lamium purpureum L. & $\begin{array}{l}\text { jasnota } \\
\text { purpurowa }\end{array}$ & (RzM), (Ch) & Zcz; Oko, Gacki 1974: 162 \\
\hline Lathyrus pratensis L. & groszek żółty & $(\mathrm{Ru})$ & $\begin{array}{r}\text { czerwiec, sierpień; Oko } 1975: \\
143,151\end{array}$ \\
\hline Lectuca L. & sałata & & $\begin{array}{r}\text { Cornau 1903: 193, k; } \\
\text { Popławski 1951: 5, k, } \\
\text { pisklęta; Konarski 1956: } \\
\text { 11, Walewski, Konarski } \\
\text { 1957: 121, k, pisklęta; } \\
\text { Sikorski 1961: 3, k, pisklęta, } \\
\text { L; Fedorowski 1963: 11, } \\
\text { k; Konarski 1966: 24, } \\
\text { Dzięciołowski, Kowalina } \\
\text { 1971: 56, N; Behnke 1995: 38, } \\
\text { Matuszewski, Morow 1994: } \\
\text { 34, Kruszewicz, Manelski } \\
2007: 43\end{array}$ \\
\hline Lens P. Miller & soczewica & & $\begin{array}{r}\text { Walewski, Konarski 1957: } \\
\text { 121, 127, k, pisklęta; Sikorski } \\
1962: 15\end{array}$ \\
\hline
\end{tabular}




\begin{tabular}{|c|c|c|c|}
\hline Nazwa łacińska & Nazwa polska & Kategoria & Źródło \\
\hline Leontodon autumnalis L. & $\begin{array}{l}\text { brodawnik } \\
\text { jesienny }\end{array}$ & (Ch) & $\begin{array}{r}\text { K, Ko, Pę, czerwiec, } \\
\text { październik; Oko 1975: 142, } \\
159\end{array}$ \\
\hline Ligustrum L. & ligustr & & $\begin{array}{r}\text { O; Walewski, Konarski 1957: } \\
\text { 40, O; Bednorz, Bogucki } \\
\text { 1961: 34, O; Dzięciołowski, } \\
\text { Kowalina 1971: 16, O; } \\
\text { Kruszewicz, Manelski 2007: } \\
43,47\end{array}$ \\
\hline Ligustrum vulgare L. & ligustr pospolity & $(\mathrm{Rk}),(\mathrm{Ro}),(\mathrm{Ru})$ & Turček 1961: 38 \\
\hline Linaria Mill. & lnica & & Cramp 1980: 508 \\
\hline Linum L. & len & & $\begin{array}{r}\text { Walewski, Konarski 1957: } \\
\text { 121, 123, N; Dzięciołowski, } \\
\text { Kowalina 1971: 50, 56, N; } \\
\text { Kruszewicz, Manelski 2007: }\end{array}$ \\
\hline Linum usitatissimum L. & len zwyczajny & $\begin{array}{l}(\mathrm{Rk}),(\mathrm{Ro}), \\
(\mathrm{Ch}),(\mathrm{Ru})\end{array}$ & $\begin{array}{r}\text { k, pisklęta; Sikorski 1962: 15, } \\
\text { k; Konarski 1966: } 20\end{array}$ \\
\hline Lolium perenne L. 110 & życica trwała & $\begin{array}{l}(\mathrm{RzM}),(\mathrm{Rk}), \\
(\mathrm{Ru})\end{array}$ & $\begin{array}{r}\text { L, marzec, N, czerwiec; } \\
\text { Oko 1962: 19, 20, kwiecień - } \\
\text { czerwiec; Oko 1975: 136, } 138 \text {, } \\
142\end{array}$ \\
\hline Lolium temulentum L. & życica roczna & $(\mathrm{Rz})$ & wrzesień; Oko 1975: 155 \\
\hline Lonicera nigra L. & $\begin{array}{l}\text { wiciokrzew } \\
\text { czarny }\end{array}$ & & Turček 1961: 39 \\
\hline $\begin{array}{l}\text { Lonicera periclymenum } \\
\text { Lour. }\end{array}$ & $\begin{array}{l}\text { wiciokrzew } \\
\text { pomorski }\end{array}$ & $(\mathrm{Rz}),(\mathrm{Ro}),(\mathrm{Ru})$ & Bartkowiak 1970: 259 \\
\hline $\begin{array}{l}\text { Lonicera xylosteum } \\
\text { Lour. }\end{array}$ & $\begin{array}{l}\text { wiciokrzew } \\
\text { pospolity }\end{array}$ & $(\mathrm{Rk}),(\mathrm{Ro})$, & $\begin{array}{r}\text { Turček 1961: 38, Bartkowiak } \\
\text { 1970: } 259\end{array}$ \\
\hline Lupinus L. & łubin & & $\begin{array}{r}\text { N; Walewski, Konarski 1957: } \\
\text { 72, Behnke 1995: } 38\end{array}$ \\
\hline Lupinus angustifolius L. & łubin niebieski & $(\mathrm{Rk}),(\mathrm{Ro}),(\mathrm{Ru})$ & Walewski, Konarski 1957: 75 \\
\hline Lupinus luteus L. & łubin pastewny & $(\mathrm{Ro}),(\mathrm{Ch}),(\mathrm{Ru})$ & Żołnierzak 1991: 21 \\
\hline Lycium barbarum L. & $\begin{array}{l}\text { kolcowój } \\
\text { pospolity }\end{array}$ & $(\mathrm{Ro}),(\mathrm{Ru})$ & $\begin{array}{r}\text { Turček 1961: 40, Bartkowiak } \\
\text { 1970: } 257\end{array}$ \\
\hline
\end{tabular}




\begin{tabular}{|c|c|c|c|}
\hline Nazwa łacińska & Nazwa polska & Kategoria & Źródło \\
\hline Malus Mill. & jabłoń & & $\begin{array}{r}\text { Walewski, Konarski 1957: } \\
\text { 67, Bartkowiak 1970: 251, } \\
\text { Glutz 1973: 364, Cramp 1980: } \\
\text { 507, O; Bobrowicz 1996: 35, } \\
\text { Gorazdowski, Jabłoński } \\
\text { 2002: 33, Mróz 2003: 100, } \\
\text { Kruszewicz, Manelski 2007: } \\
43,47\end{array}$ \\
\hline Malus pumila Mill. & jabłoń niska & (Ro) & Turček 1961: 40 \\
\hline $\begin{array}{l}\text { Malus x purpura } \\
\text { Red.'Szafer' }\end{array}$ & jabłoń 'Szafer' & $(\mathrm{Rk}),(\mathrm{Ro})$ & $\begin{array}{l}\text { (O)Park Ursynów } \\
\text { Wojtatowicz } 1982\end{array}$ \\
\hline Medicago L. & lucerna & & $\begin{array}{r}\text { Walewski, Konarski 1957: 41, } \\
\text { 121, L; Fedorowski 1961: 15, } \\
\text { Nowak 1961: 125, L, maj, N, } \\
\text { czerwiec; Oko 1962: 19, 20, } \\
\text { k, pisklęta; Konarski 1966: } \\
\text { 20, Dzięciołowski, Kowalina } \\
\text { 1971: 58, k; Gawęcki, } \\
\text { Torgowski 1974: 6, Wielbo, } \\
\text { Dziedzic 1974: 6, luty, Ko, } \\
\text { Pę, grudzień; Oko 1975: 131, } \\
\text { 136, 165, k; Skrzypek 1981: } \\
\text { 10, k; Skrzypek 1981a: 5, } \\
\text { Żołnierzak 1991: 21, Behnke } \\
\text { 1995: 39, L, Pę; Mróz 2003: } \\
\text { 46, N; Mróz 2003: 46, N; } \\
\text { Kruszewicz, Manelski 2007: } \\
\text { 83 }\end{array}$ \\
\hline Medicago lupulina L. & $\begin{array}{l}\text { lucerna } \\
\text { nerkowata }\end{array}$ & (Rk), (Rur) & N; Oko, Gacki 1974: 160 \\
\hline Medicago sativa $\mathrm{L}$. & lucerna siewna & (Rur) & $\begin{array}{r}\text { L, kwiecień; Oko 1962: 19, } \\
\text { N; Oko, Gacki 1974: 160, Ko, } \\
\text { Pę, styczeń, luty, kwiecień, } \\
\text { październik; Oko 1975: 129, } \\
\text { 131, 132, 136, } 159\end{array}$ \\
\hline Melilotus albus Medik. & nostrzyk biały & $\begin{array}{l}\text { (Rk), (Ru), } \\
\text { (Rur) }\end{array}$ & Dzięciołowski 1961: 14 \\
\hline
\end{tabular}




\begin{tabular}{|c|c|c|c|}
\hline Nazwa łacińska & Nazwa polska & Kategoria & Źródło \\
\hline Morus alba $\mathrm{L}$. & morwa biała & $(\mathrm{Rk}),(\mathrm{Ro}),(\mathrm{Ru})$ & $\begin{array}{r}\text { Turček 1961: 40, Bartkowiak } \\
\text { 1970: } 249\end{array}$ \\
\hline $\begin{array}{l}\text { Myosotis arvensis }(\mathrm{L}) . \\
\text { Hill }\end{array}$ & $\begin{array}{l}\text { niezapominajka } \\
\text { polna }\end{array}$ & (RzM), (Ch) & $\begin{array}{r}\text { N; Gacki 1974: 7, N; Oko, } \\
\text { Gacki 1974: } 160\end{array}$ \\
\hline $\begin{array}{l}\text { Onobrychis viciifolia } \\
\text { Scop. }\end{array}$ & sparceta siewna & (Rk), (Rur) & $\begin{array}{r}\text { Walewski, Konarski 1957: } \\
121\end{array}$ \\
\hline Ornithopus L. & saradela & & $\begin{array}{r}\text { Walewski, Konarski 1957: 41, } \\
\text { Ko, Pę, sierpień; Oko 1975: } \\
\text { 152, 165, Żołnierzak 1991: } 21\end{array}$ \\
\hline $\begin{array}{l}\text { Ornithopus perpusillus } \\
\text { L. }\end{array}$ & seradela drobna & & $\begin{array}{r}\text { N, O, luty, lipiec, sierpień; } \\
\text { Oko 1975: 131, 145, } 151\end{array}$ \\
\hline $\begin{array}{l}\text { Ornithopus satious } \\
\text { Brot. }\end{array}$ & $\begin{array}{l}\text { seradela } \\
\text { pastewna }\end{array}$ & (Rk), (Rur) & $\begin{array}{r}\text { Ko, N, O, Pę, maj, } \\
\text { październik - grudzień; Oko } \\
\text { 1975: 138, 159, 161, } 164\end{array}$ \\
\hline Panicum L. & proso & & $\begin{array}{r}\text { Cornau 1903: 193, Pęski } \\
\text { 1928: 19, Dembinok 1956: } \\
\text { 11, k; Walewski, Konarski } \\
\text { 1957: 40, 154, N; Sokołowski } \\
\text { 1958: 146, Nowak 1961: 125, } \\
\text { N, maj, L; Oko 1962: 17, 19, } \\
\text { k, pisklęta; Sikorski 1962: 15, } \\
\text { N; Dzięciołowski, Kowalina } \\
\text { 1971: 17, N; Sokołowski } \\
\text { 1972: 119, N; Mróz 2003: } 49, \\
\text { N; Okarma 2008: } 331\end{array}$ \\
\hline Papaver L. & mak & & $\begin{array}{r}\text { k, N; Walewski, Konarski } \\
\text { 1957: 154, N; Dzięciołowski, } \\
\text { Kowalina 1971: 50, 56,N; } \\
\text { Lempaszak 1977: } 7\end{array}$ \\
\hline Papaver argemone $\mathrm{L}$. & mak piaskowy & $\begin{array}{l}(\mathrm{RzM}),(\mathrm{Rk}) \\
(\mathrm{Ro}),(\mathrm{Ch}),(\mathrm{Ru})\end{array}$ & $\begin{array}{r}\text { N; Oko, Gacki 1974: 160, N, } \\
\text { O, październik; Oko 1975: } \\
158\end{array}$ \\
\hline Papaver rhoeas L. & mak polny & $\begin{array}{l}(\mathrm{RzM}),(\mathrm{Rk}) \\
(\mathrm{Ro}),(\mathrm{Ch}),(\mathrm{Ru})\end{array}$ & $\begin{array}{r}\text { N; Oko, Gacki 1974: 160, N, } \\
\text { O, lipiec - październik; Oko } \\
\text { 1975: 146, 150, 155, } 158\end{array}$ \\
\hline $\begin{array}{l}\text { Pennisetum glaucum } \\
\text { (L.) R.Br. }\end{array}$ & włośnica sina & (Ch) & $\begin{array}{r}\text { N, O, kwiecień, grudzień; } \\
\text { Oko 1975: 136,164 }\end{array}$ \\
\hline
\end{tabular}




\begin{tabular}{|c|c|c|c|}
\hline Nazwa łacińska & Nazwa polska & Kategoria & Źródło \\
\hline Persicaria L. & rdest & & $\begin{array}{r}\text { Szederjei 1958: 13, Glutz } \\
\text { 1973: 363, N; Gacki 1974: } \\
\text { 7, N; Oko, Gacki 1974: 159, } \\
\text { N, O, styczeń - wrzesien, } \\
\text { listopad, grudzień; Oko } \\
\text { 1975: 129, 130, 133, 135, } \\
\text { 138, 141, 146, 150, 154, 161, } \\
\text { 164, N; Lempaszak 1977: } \\
\text { 7, Cramp 1980: 507, 508, L; } \\
\text { Kruszewicz, Manelski 2007: } \\
46\end{array}$ \\
\hline Petroselinum J. Hill & pietruszka & & $\begin{array}{r}\text { Gorazdowski, Jabłoński } \\
2002: 34\end{array}$ \\
\hline $\begin{array}{l}\text { Phaseolus vulgaris L. } \\
90\end{array}$ & fasola zwykła & (Rk), (Rur) & $\begin{array}{r}\text { październik - grudzień; Oko } \\
1975: 159,161,164\end{array}$ \\
\hline Phleum L. & tymotka & & N; Gacki 1974: 7 \\
\hline Phleum pratense $\mathrm{L}$. & tymotka łąkowa & $(\mathrm{Ru})$ & $\begin{array}{r}\text { N, Zcz; Oko, Gacki 1974: } \\
159,161\end{array}$ \\
\hline $\begin{array}{l}\text { Picea orientalis (L.) } \\
\text { Peterm. }\end{array}$ & świerk kaukaski & $(\mathrm{Rk}),(\mathrm{Ro}),(\mathrm{Ru})$ & Turček 1961: 44 \\
\hline Pinus L. & sosna & & Li; Skrzypek 1981: 10 \\
\hline Pinus sylvestris L. & sosna zwyczajna & $(\mathrm{Rk}),(\mathrm{Ro}),(\mathrm{Ru})$ & Turček 1961: 45 \\
\hline Pisum L. & groch & & $\begin{array}{r}\text { Dembinok 1956: 11, } \\
\text { Walewski, Konarski 1957: } \\
\text { 121, N, O, grudzień; Oko } \\
\text { 1975: } 165\end{array}$ \\
\hline Pisum sativum L. & groch zwyczajny & (Rk), (Rur) & $\begin{array}{r}\text { N; Oko, Gacki 1974: 160, N, } \\
\text { O, luty - kwiecień, wrzesień; } \\
\text { Oko 1975: 131, 133, 135, } 155\end{array}$ \\
\hline Plantago L. & babka & & $\begin{array}{r}\text { Glutz 1973: 364, kwiecień; } \\
\text { Oko 1975: } 136\end{array}$ \\
\hline Plantago lanceolata $\mathrm{L}$. & $\begin{array}{l}\text { babka } \\
\text { lancetowata }\end{array}$ & $(\mathrm{Ch}),(\mathrm{Ru})$ & $\begin{array}{r}\text { Glutz 1973: 363, Gacki 1974: } \\
\text { 7, N; Oko, Gacki 1974: 159, } \\
\text { 161, Ko, Pę, luty, maj; Oko } \\
\text { 1975: 131, 132, 139, Pę; } \\
\text { Lempaszak 1977: } 7\end{array}$ \\
\hline Plantago major $\mathrm{L}$. & babka zwyczajna & $(\mathrm{Ch}),(\mathrm{Ru})$ & $\begin{array}{l}\text { N; Oko, Gacki 1974: 159, } \\
\text { kwiecień; Oko 1975: } 136\end{array}$ \\
\hline
\end{tabular}




\begin{tabular}{|c|c|c|c|}
\hline Nazwa łacińska & Nazwa polska & Kategoria & Źródło \\
\hline Poa annua L. & wiechlina roczna & $(\mathrm{Ch})$ & $\begin{array}{r}\text { L, marzec; Oko 1962: 19, } \\
\text { Glutz 1973: 364, L; Gacki } \\
\text { 1974: 7, Zcz; Oko, Gacki } \\
\text { 1974: 161, Ko, Pę, marzec, N, } \\
\text { maj, sierpień, wrzesień; Oko } \\
\text { 1975: 134, 138, 151, 155, L; } \\
\text { Lempaszak 1977: } 7\end{array}$ \\
\hline Poa pratensis L. & wiechlina łąkowa & $(\mathrm{Ru})$ & $\begin{array}{r}\text { N, czerwiec; Oko 1962: 20, } \\
\text { Zcz; Oko, Gacki 1974: 161, } \\
\text { N, czerwiec, lipiec; Oko } \\
\text { 1975: 142, } 146\end{array}$ \\
\hline Poaceae (R. Br.) Barnh. & trawy & & $\begin{array}{r}\text { Walewski, Konarski 1957: } \\
\text { 41, Nowak 1961: 125, N; } \\
\text { Dzięciołowski, Kowalina } \\
\text { 1971: 17, Zcz; Oko, Gacki } \\
\text { 1974: 161, Ko, Pę, styczen } \\
\text { - czerwiec, sierpień - } \\
\text { grudzień; 129, 131, 133, } \\
\text { 136, 138, 143, 151, 156, 158, } \\
\text { 162, 164, Behnke 1995: 18, } \\
\text { N; Łogin 1995: 12, L, N, Pę; } \\
\text { Mróz 2003: 46, Kruszewicz, } \\
\text { Manelski 2007: 45, N; } \\
\text { Matysek 2010: } 43\end{array}$ \\
\hline Polypodium vulgare L. & $\begin{array}{l}\text { paprotka } \\
\text { zwyczajna }\end{array}$ & (Rk), (Ro) & Glutz 1973: 364 \\
\hline Populus L. & topola & & $\begin{array}{r}\text { L, Pę; Kruszewicz, Manelski } \\
\text { 2007: } 46\end{array}$ \\
\hline Potentilla L. & pięciornik & & $\begin{array}{r}\text { Gorazdowski, Jabłoński } \\
2002: 34\end{array}$ \\
\hline Prunus L. & śliwa & & $\begin{array}{r}\text { O; Walewski, Konarski 1957: } \\
\text { 40, Dzięciołowski, Kowalina } \\
\text { 1971: 16, O; Mróz 2003: 49, } \\
\text { Mróz 2003: } 100\end{array}$ \\
\hline Prunus domestica L. 80 & śliwa domowa & $(\mathrm{Rk}),(\mathrm{Ro}),(\mathrm{Ru})$ & $\begin{array}{r}\text { Turček 1961: 47, Bartkowiak } \\
\text { 1970: } 252\end{array}$ \\
\hline Prunus insititia L. & śliwa lubaszka & $(\mathrm{Rk}),(\mathrm{Ro}),(\mathrm{Ru})$ & Bartkowiak 1970: 252 \\
\hline
\end{tabular}




\begin{tabular}{|c|c|c|c|}
\hline Nazwa łacińska & Nazwa polska & Kategoria & Źródło \\
\hline Prunus spinosa L. & śliwa tarnina & $(\mathrm{Rk}),(\mathrm{Ro}),(\mathrm{Ru})$ & $\begin{array}{r}\text { Walewski, Konarski } \\
\text { 1957: 122, Turček 1961: } \\
\text { 48, Bartkowiak 1970: } \\
\text { 252, O; Dzięciołowski, } \\
\text { Kowalina1971: 17, N, luty, } \\
\text { marzec, wrzesień, listopad; } \\
\text { Oko 1975: 131, 133, 155, } \\
\text { 161, Cramp 1980: 507, 508, } \\
\text { N; Gorazdowski, Jabłoński } \\
\text { 2002: 33, N; Okarma 2008: }\end{array}$ \\
\hline Pyracantha M.Roem. & ognik & & $\begin{array}{r}\text { Kruszewicz, Manelski 2007: } \\
47\end{array}$ \\
\hline Pyrus L. & grusza & & $\begin{array}{r}\text { O; Walewski, Konarski 1957: } \\
\text { 67, Mróz 2003: } 100\end{array}$ \\
\hline Pyrus communis L. & grusza pospolita & $(\mathrm{Rk}),(\mathrm{Ro}),(\mathrm{Ru})$ & Turček 1961: 46 \\
\hline Quercus L. & dąb & & $\begin{array}{r}\text { O; Cornau 1903: 29, O; Pęski } \\
\text { 1928: 19, O; Dembinok 1956: } \\
\text { 11,O; Walewski, Konarski } \\
\text { 1957: 40, 67, 122, O, galasy; } \\
\text { Sokołowski 1958: 146, } \\
\text { O, galasy; Dzięciołowski } \\
\text { 1964: 15, O; Dzięciołowski, } \\
\text { Kowalina 1971: 17, O, galasy; } \\
\text { Sokołowski 1972: 119, } \\
\text { Cramp 1980: 507, Behnke } \\
\text { 1995: 18, O; Gorazdowski, } \\
\text { Jabłoński 2002: 33, O; Mróz } \\
\text { 2003: 49, O pokruszone; } \\
\text { Kruszewicz, Manelski 2007: } \\
44,47\end{array}$ \\
\hline $\begin{array}{l}\text { Quercus petraea (Matt.) } \\
\text { Liebl. }\end{array}$ & $\begin{array}{l}\text { dąb } \\
\text { bezszypułkowy }\end{array}$ & $(\mathrm{Rk}),(\mathrm{Ro}),(\mathrm{Ru})$ & $\begin{array}{r}\text { Bartkowiak 1970: 249, O, } \\
\text { grudzień; Oko 1975: 164, O; } \\
\text { Okarma 2008: 331, Klau., JW, } \\
2000\end{array}$ \\
\hline $\begin{array}{l}\text { Quercus pubescens } \\
\text { Willd. }\end{array}$ & dąb omszony & $(\mathrm{Rz}),(\mathrm{Rk}),(\mathrm{Ro})$ & Turček 1961: 52 \\
\hline
\end{tabular}




\begin{tabular}{|c|c|c|c|}
\hline Nazwa łacińska & Nazwa polska & Kategoria & Źródło \\
\hline Quercus robur $\mathrm{L}$. & dąb szypułkowy & $(\mathrm{Rk}),(\mathrm{Ro}),(\mathrm{Ru})$ & $\begin{array}{r}\text { Bartkowiak 1970: 249, Glutz } \\
\text { 1973: 364, Cramp 1980: 508, } \\
\text { O; Okarma 2008: } 331\end{array}$ \\
\hline Rhamnus cathartica L. & szakłak pospolity & $(\mathrm{Ru})$ & Turček 1961: 52 \\
\hline Ranunculus L. & jaskier & & $\begin{array}{r}\text { Glutz 1973: 364, K, kwiecień, } \\
\text { N, maj, K, Ko, Pę, lipiec; Oko } \\
\text { 1975: 136, 138, } 151\end{array}$ \\
\hline Ranunculus acris L. & jaskier ostry & $\begin{array}{l}\text { (Rk), (Ro), } \\
(\mathrm{Ch}),(\mathrm{Ru})\end{array}$ & $\begin{array}{r}\text { K, L, Pa, maj, N, wrzesień; } \\
\text { Oko 1962: 19, 20, 22, K, Ko, } \\
\text { N, O Pę, kwiecień, czerwiec } \\
\text { - sierpień; Oko 1975: 136, } \\
\text { 142, 145, 150, } 151\end{array}$ \\
\hline Ranunculus arvensis L. & jaskier polny & $(\mathrm{Rz}),(\mathrm{RzM})$ & $\begin{array}{r}\text { K, Ko, N, Pę, maj, czerwiec; } \\
\text { Oko 1975: 138, 139, } 142\end{array}$ \\
\hline $\begin{array}{l}\text { Rannunculus bulbosus } \\
\text { L. } 70\end{array}$ & jaskier bulwkowy & (Ro) & Glutz 1973: 363 \\
\hline $\begin{array}{l}\text { Ranunculus } \\
\text { lanuginosus L. }\end{array}$ & jaskier kosmaty & (Ro) & N, O, maj; Oko 1975: 138 \\
\hline $\begin{array}{l}\text { Ranunculus } \\
\text { polyanthemos L. }\end{array}$ & $\begin{array}{l}\text { jaskier } \\
\text { wielokwiatowy }\end{array}$ & (Ro) & sierpień; Oko 1975: 150 \\
\hline Ranunculus repens L. & jaskier rozłogowy & $\begin{array}{l}(\mathrm{RzM}),(\mathrm{Rk}), \\
(\mathrm{Ro}),(\mathrm{Ch})\end{array}$ & $\begin{array}{l}\text { L, kwiecień; Oko 1962: 19, } \\
\text { K, maj, czerwiec, N, lipiec, } \\
\text { sierpień, październik; Oko } \\
\text { 1975: 138, 142, 146, 150, } 158\end{array}$ \\
\hline $\begin{array}{l}\text { Raphanus raphanistrum } \\
\text { L. }\end{array}$ & $\begin{array}{l}\text { rzodkiew } \\
\text { świrzepa }\end{array}$ & $\begin{array}{l}\text { (Rk), (Ch), } \\
\text { (Rur), (Ru) }\end{array}$ & $\begin{array}{r}\text { k; Walewski, Konarski 1957: } \\
\text { 153, K, Ko, Pę, sierpień, } \\
\text { wrzesień; Oko 1975: 151, } 156\end{array}$ \\
\hline Ribes L. & porzeczka & & $\begin{array}{r}\text { Kruszewicz, Manelski 2007: } \\
47\end{array}$ \\
\hline Ribes nigrum L. & porzeczka czarna & $\begin{array}{l}(\mathrm{RzM}),(\mathrm{Rz}), \\
(\mathrm{Rk}),(\mathrm{Ru})\end{array}$ & Bartkowiak 1970: 250 \\
\hline Ribes rubrum $\mathrm{L}$. & $\begin{array}{l}\text { porzeczka } \\
\text { zwyczajna }\end{array}$ & $(\mathrm{Rk}),(\mathrm{Ru})$ & $\begin{array}{r}\text { Turček 1961: 54, Bartkowiak } \\
\text { 1970: } 250\end{array}$ \\
\hline
\end{tabular}




\begin{tabular}{|c|c|c|c|}
\hline Nazwa łacińska & Nazwa polska & Kategoria & Źródło \\
\hline Robinia pseudoacacia L. & robinia akacjowa & $(\mathrm{Rk}),(\mathrm{Ro}),(\mathrm{Ru})$ & $\begin{array}{r}\text { Turček 1961: 55, Glutz 1973: } \\
\text { 362, O; Oko, Gacki 1974: 160, } \\
\text { N, O, luty - maj, sierpień, } \\
\text { listopad, grudzień; Oko } \\
\text { 1975: 131, 133, 135, 138, 151, } \\
\text { 162, 164, O; Stankiewicz } \\
\text { 2000a: } 26\end{array}$ \\
\hline $\begin{array}{l}\text { Rorippa amphibia (L.) } \\
\text { Besser }\end{array}$ & $\begin{array}{l}\text { rzepicha } \\
\text { ziemnowodna }\end{array}$ & & N, luty; Oko 1975: 131 \\
\hline Rosa L. & róża & & Glutz 1973: 363 \\
\hline Rosa canina L. & róża dzika & $(\mathrm{Rk}),(\mathrm{Ro}),(\mathrm{Ru})$ & $\begin{array}{r}\text { Dembinok 1956: 11, O; } \\
\text { Walewski, Konarski 1957: 40, } \\
\text { O; Dzięciołowski, Kowalina } \\
\text { 1971: 17, N; Gorazdowski, } \\
\text { Jabłoński 2002: 33, O; Mróz } \\
\text { 2003: 49, N; Okarma 2008: } \\
331\end{array}$ \\
\hline Rosa pendulina L.60 & róża alpejska & (Ro) & Turček 1961: 55 \\
\hline Rosa rugosa Thunb. & $\begin{array}{l}\text { róża } \\
\text { pomarszczona }\end{array}$ & $\begin{array}{l}\text { (Rk), (Ro), } \\
(\mathrm{Ch}),(\mathrm{Ru})\end{array}$ & Emil., JW, 2010 \\
\hline Rosaceae Juss. & różowate & & sierpień; Oko 1975: 152 \\
\hline Rubus L. & jeżyna & & $\begin{array}{r}\text { Dembinok 1956: 11, O; } \\
\text { Walewski, Konarski 1957: } \\
\text { 40, 67, 122, Nowak 1961: 125, } \\
\text { O; Dzięciołowski, Kowalina } \\
\text { 1971: 16, N, O, sierpień, } \\
\text { wrzesień; Oko 1975: 151, } \\
\text { 155, O; Mróz 2003: 49, } \\
\text { Kruszewicz, Manelski 2007: }\end{array}$ \\
\hline Rubus caesius L. & jeżyna popielica & (Rk), (Ru) & Turček 1961: 56 \\
\hline
\end{tabular}




\begin{tabular}{|c|c|c|c|}
\hline Nazwa łacińska & Nazwa polska & Kategoria & Źródło \\
\hline Rubus idaeus L. & malina właściwa & $(\mathrm{Rk}),(\mathrm{Ru})$ & $\begin{array}{r}\text { Dembinok 1956: 11, O; } \\
\text { Walewski, Konarski 1957: } \\
\text { 40, 67, 122, Nowak 1961: } \\
\text { 125, Turček 1961: 57, O; } \\
\text { Dzięciołowski, Kowalina } \\
\text { 1971: 16, Cramp 1980: 507, O; } \\
\text { Mróz 2003: 49, Kruszewicz, } \\
\text { Manelski 2007: } 47\end{array}$ \\
\hline $\begin{array}{l}\text { Rubus plicatus Weihe } \\
\text { \& Nees }\end{array}$ & jeżyna fałdowana & $(\mathrm{Rk}),(\mathrm{Ch}),(\mathrm{Ru})$ & $\begin{array}{r}\text { sierpień, wrzesień; Oko } \\
1975: 151,155 \\
\end{array}$ \\
\hline Rubus saxatilis L. & malina kamionka & $(\mathrm{Ru})$ & $\begin{array}{r}\text { O, wrzesień, październik; } \\
\text { Oko 1975: 155, } 158 \\
\end{array}$ \\
\hline Rumex L. & szczaw & & $\begin{array}{r}\text { Glutz 1973: 364, N, O, } \\
\text { październik; Oko 1975: 158, } \\
\text { N; Mróz 2003: } 46\end{array}$ \\
\hline Rumex acetosella $\mathrm{L}$. & szczaw polny & $(\mathrm{Ru})$ & $\begin{array}{r}\text { N; Gacki 1974: 7, N; } \\
\text { Oko, Gacki 1974: 159, N, } \\
\text { październik; Oko 1975: 158, } \\
\text { Cramp 1980: } 507\end{array}$ \\
\hline Rumex obtusifolius L. & szczaw tępolistny & $(\mathrm{Ru})$ & N; Oko, Gacki 1974: 159 \\
\hline Salix L. & wierzba & & $\begin{array}{r}\text { L, Pę; Kruszewicz, Manelski } \\
\text { 2007: } 46\end{array}$ \\
\hline Sambucus ebulus L. & bez hebd & $(\mathrm{Ro}),(\mathrm{Ru})$ & Turček 1961: 62 \\
\hline Sambucus nigra L. & bez czarny & $(\mathrm{Ro}),(\mathrm{Ru})$ & $\begin{array}{r}\text { Turček 1961: 59, Bartkowiak } \\
\text { 1970: 258, Glutz 1973: 364, N, } \\
\text { O, listopad; Oko 1975: 161, } \\
\text { O; Gorazdowski, Jabłoński } \\
\text { 2002: 34, Kruszewicz, } \\
\text { Manelski 2007: 43, } 47\end{array}$ \\
\hline Sambucus racemosa L. & bez koralowy & $(\mathrm{Ro}),(\mathrm{Ru})$ & Bartkowiak 1970: 258 \\
\hline Scleranthus L. & czerwiec & & N; Oko 1975: 164 \\
\hline Scleranthus annuus L. & czerwiec roczny & (Ch) & Glutz 1973: 363 \\
\hline Secale L. & żyto & & $\begin{array}{r}\text { N; Gorazdowski, Jabłoński } \\
2002: 34\end{array}$ \\
\hline
\end{tabular}




\begin{tabular}{|c|c|c|c|}
\hline Nazwa łacińska & Nazwa polska & Kategoria & Źródło \\
\hline Secale cereale $\mathrm{L}$. & żyto zwyczajne & $\begin{array}{l}\text { (Rk), (Ro), } \\
\text { (Rur) }\end{array}$ & $\begin{array}{r}\text { N; Walewski, Konarski 1957: } \\
\text { 40, L, marzec, maj; Oko } \\
\text { 1962: 19, Zcz, kwiecień; Oko } \\
\text { 1962: 19, N; Dzięciołowski, } \\
\text { Kowalina 1971: 17, N; Glutz } \\
\text { 1973: 364, Gacki 1974: 7, N; } \\
\text { Oko, Gacki 1974: 159, N, } \\
\text { styczeń - marzec, lipiec - } \\
\text { grudzień; Oko 1975: 129, } \\
\text { 130, 132, 134, 146, 150, 154, } \\
\text { 158, 161, 164, N; Kruszewicz, } \\
\text { Manelski 2007: 83 }\end{array}$ \\
\hline Secale montanum Guss. & żyto krzyca & $\begin{array}{l}\text { (Rk), (Ro), } \\
\text { (Rur) }\end{array}$ & $\begin{array}{r}\text { Pę; Walewski, Konarski } \\
1957: 74\end{array}$ \\
\hline Setaria P. Beauv. & włośnica & & $\begin{array}{r}\text { styczeń, luty, listopad; Oko } \\
1975: 130,132,162 \\
\end{array}$ \\
\hline $\begin{array}{l}\text { Setaria italica (L.) } \\
\text { P.Beauv. }\end{array}$ & włośnica ber & (Rk) & Feil 1950: 20 \\
\hline $\begin{array}{l}\text { Setaria viridis (L.) } \\
\text { P.Beauv. }\end{array}$ & włośnica zielona & $(\mathrm{Ch}),(\mathrm{Ru})$ & $\begin{array}{r}\text { Szederjei 1958: 13, N } \\
\text { kwiecień, L, N, Pę sierpień, } \\
\text { wrzesień; Oko 1962: 17, 19, } \\
\text { 22, N; Oko, Gacki 1974: 159, } \\
\text { luty, maj, czerwiec, sierpień, } \\
\text { październik; Oko 1975: 131, } \\
\text { 138, 142, 151, } 159 \\
\end{array}$ \\
\hline Silene latifolia Poir. & lepnica biała & $(\mathrm{Ch}),(\mathrm{Ru})$ & $\begin{array}{r}\text { N; Oko, Gacki 1974: 160, } \\
\text { październik; Oko 1975: } 158\end{array}$ \\
\hline Sinapis L. & gorczyca & & $\begin{array}{r}\text { k; Walewski, Konarski 1957: } \\
\text { 153, Nowak 1961: 125, N; } \\
\text { Dzięciołowski, Kowalina } \\
\text { 1971: 17, N; Mróz 2003: } 49\end{array}$ \\
\hline Sinapis arvensis L. & gorczyca polna & $\begin{array}{l}\text { (RzM), (Rk), } \\
(\mathrm{Ch})\end{array}$ & $\begin{array}{r}\text { N; Walewski, Konarski } \\
\text { 1957: 40, K, Pa; Oko 1962: } \\
\text { 20, N; Gacki 1974: 7, Zcz; } \\
\text { Oko, Gacki 1974: 161, K, } \\
\text { Ko, Pę, maj, N, O, sierpień, } \\
\text { K, grudzień; Oko 1975: 139, } \\
150,164\end{array}$ \\
\hline
\end{tabular}




\begin{tabular}{|c|c|c|c|}
\hline Nazwa łacińska & Nazwa polska & Kategoria & Źródło \\
\hline Solanum L. & psianka & & $\begin{array}{r}\text { O; Sokołowski 1958: 146, O; } \\
\text { Sokołowski 1972: } 119\end{array}$ \\
\hline $\begin{array}{l}\text { Solanum americanum } \\
\text { Mill. }\end{array}$ & psianka czarna & (Ch) & $\begin{array}{r}\text { Glutz 1973: 362, 364, Cramp } \\
1980: 508\end{array}$ \\
\hline Solanum dulcamara L. & $\begin{array}{l}\text { psianka } \\
\text { słodkogórz }\end{array}$ & $(\mathrm{Ru})$ & $\begin{array}{r}\text { Glutz 1973: 362, Cramp 1980: } \\
508\end{array}$ \\
\hline $\begin{array}{l}\text { Solanum tuberosum } \\
\text { L. } 40\end{array}$ & ziemniak & (Rk), (Rur) & $\begin{array}{r}\text { Jonkisz 1931: 8, Walewski, } \\
\text { Konarski 1957: 41, } \\
\text { Sokołowski 1958: 146, L; } \\
\text { Dzięciołowski, Kowalina } \\
\text { 1971: 17, Sokołowski 1972: } \\
\text { 119, Glutz 1973: 364, Bk; } \\
\text { Gacki 1974: 7, Bk, Zcz; Oko, } \\
\text { Gacki 1974: 162, Bk, styczeń, } \\
\text { luty, kwiecień, maj, lipiec } \\
\text { - grudzień; Oko 1975: 129, } \\
\text { 131, 136, 139, 146, 152, 156, } \\
\text { 159, 162, 165, Bk; Lempaszak } \\
\text { 1977: 7, Łukasik 1996: 234, } \\
\text { Gorazdowski, Jabłoński } \\
\text { 2002: 33, Bk; Mróz 2003: 49 }\end{array}$ \\
\hline Sorbus L. & jarząb & & $\begin{array}{r}\text { O; Walewski, Konarski } \\
\text { 1957: 40, 67, 122, O; } \\
\text { Dzięciołowski, Kowalina } \\
\text { 1971: 17, O; Behnke 1995: 39, } \\
\text { O; Gorazdowski, Jabłoński } \\
\text { 2002: 34, O; Kruszewicz, } \\
\text { Manelski 2007: 43, 47, N; } \\
\text { Okarma 2008: } 331\end{array}$ \\
\hline Sorbus aucuparia L. & jarząb pospolity & $(\mathrm{Rk}),(\mathrm{Ro}),(\mathrm{Ru})$ & $\begin{array}{r}\text { Turček 1961: 62, Bartkowiak } \\
\text { 1970: } 251\end{array}$ \\
\hline $\begin{array}{l}\text { Sorbus torminalis (L.) } \\
\text { Crantz }\end{array}$ & jarząb brekinia & $(\mathrm{Rz}),(\mathrm{Rk}),(\mathrm{Ro})$ & $\begin{array}{r}\text { Turček 1961: 64, Bartkowiak } \\
\text { 1970: } 251\end{array}$ \\
\hline Sorghum Moench & sorgo & & $\begin{array}{r}\text { Rudecka 1987: 16, N; Mróz } \\
2003: 46\end{array}$ \\
\hline
\end{tabular}




\begin{tabular}{|c|c|c|c|}
\hline Nazwa łacińska & Nazwa polska & Kategoria & Źródło \\
\hline Spergula arvensis L. & sporek polny & $(\mathrm{Rz}),(\mathrm{Ch}),(\mathrm{Ru})$ & $\begin{array}{r}\text { N, czerwiec - wrzesień; Oko } \\
\text { 1962: 20, 22, Glutz 1973: 364, } \\
\text { N, O, czerwiec - wrzesień, } \\
\text { listopad, grudzień; Oko } \\
\text { 1975: 141, 146, 150, 155, } 161, \\
164\end{array}$ \\
\hline Spinacia L. & szpinak & & $\begin{array}{r}\text { Walewski, Konarski 1957: } \\
\text { 121, k; Skrzypek 1981: 10, } \\
\text { Gorazdowski, Jabłoński } \\
2002: 34\end{array}$ \\
\hline Staphylea pinnata L. & $\begin{array}{l}\text { kłokoczka } \\
\text { południowa }\end{array}$ & $(\mathrm{Ru})$ & Turček 1961: 65 \\
\hline Stellaria L. & gwiazdnica & & $\begin{array}{r}\text { czerwiec; Oko 1975: 143, } \\
\text { Gorazdowski, Jabłoński } \\
\text { 2002: 34, Mróz 2003: 99, L; } \\
\text { Kruszewicz, Manelski 2007: } \\
46\end{array}$ \\
\hline Stellaria media (L). Vill & $\begin{array}{l}\text { gwiazdnica } \\
\text { pospolita }\end{array}$ & $(\mathrm{Ch}),(\mathrm{Ru})$ & $\begin{array}{r}\text { Glutz 1973: 363, N; Gacki } \\
\text { 1974: 7, Zcz; Oko, Gacki } \\
\text { 1974: 161, N, luty, czerwiec - } \\
\text { grudzień; Oko1975: 131, 141, } \\
\text { 146, 150, 155, 156, 158, 161, } \\
\text { 164, N; Lempaszak 1977: 7, } \\
\text { Cramp 1980: } 508\end{array}$ \\
\hline $\begin{array}{l}\text { Symphoricarpos albus } \\
\text { (L.) S.F.Blake }\end{array}$ & śnieguliczka biała & (Rk), (Ro) & $\begin{array}{r}\text { Turček 1961: 65, Bartkowiak } \\
\text { 1970: 258, N, O, sierpień, } \\
\text { wrzesień, grudzień; Oko } \\
\text { 1975: 151, 155, } 165\end{array}$ \\
\hline Symphytum L. & żywokost & & $\begin{array}{r}\text { k; Walewski, Konarski } \\
\text { 1957: 153, N; Dzięciołowski, } \\
\text { Kowalina 1971: 50, } 56\end{array}$ \\
\hline Taraxacum F.H. Wigg. & mniszek & & $\begin{array}{r}\text { L; Kruszewicz, Manelski } \\
2007: 46, \text { WT }\end{array}$ \\
\hline
\end{tabular}




\begin{tabular}{|c|c|c|c|}
\hline Nazwa łacińska & Nazwa polska & Kategoria & Źródło \\
\hline $\begin{array}{l}\text { Taraxacum officinale } \\
\text { Webb }\end{array}$ & mniszek lekarski & $(\mathrm{Rk}),(\mathrm{Ch}),(\mathrm{Ru})$ & $\begin{array}{r}\text { K, Pą; Oko 1962: 20, Ko, } \\
\text { Pę, kwiecień, K, czerwiec, } \\
\text { Ko, Pę, sierpień, wrzesień; } \\
\text { Oko 1975: 136, 142, 152, 156, } \\
\text { Gorazdowski, Jabłoński } \\
\text { 2002: 34, Mróz 2003: } 99\end{array}$ \\
\hline Taxus baccata L. & cis pospolity & $(\mathrm{Ro}),(\mathrm{Ru})$ & Turček 1961: 66 \\
\hline Thlaspi arvense L. & tobołki polne & $(\mathrm{Ch})$ & $\begin{array}{r}\text { K, N; Gacki 1974: 7, K, Li, N; } \\
\text { Oko, Gacki 1974: 160, 161, } \\
\text { Ko, Pę, październik; Oko } \\
1975: 159\end{array}$ \\
\hline Tilia cordata Mill. & lipa drobnolistna & $(\mathrm{Rk}),(\mathrm{Ro}),(\mathrm{Ru})$ & O; Stankiewicz 2000: 23 \\
\hline Tilia platyphyllos Scop. & lipa szerokolistna & $(\mathrm{Rk}),(\mathrm{Ro}),(\mathrm{Ru})$ & $\begin{array}{r}\text { Turček 1961: 67, O; } \\
\text { Stankiewicz 2000: } 23\end{array}$ \\
\hline $\begin{array}{l}\text { Torilis japonica } \\
\text { (Houtt.) DC. }\end{array}$ & $\begin{array}{l}\text { kłobuczka } \\
\text { pospolita }\end{array}$ & & $\begin{array}{r}\text { Gacki 1974: 7, K, Zcz; Oko, } \\
\text { Gacki 1974: } 162\end{array}$ \\
\hline Trifolium L. & koniczyna & & $\begin{array}{r}\text { Walewski, Konarski 1957: 41, } \\
\text { 121, Sokołowski 1958: 146, } \\
\text { k, pisklęta; Sikorski 1961:3, } \\
\text { k, pisklęta; Konarski 1966: } \\
\text { 20, Dzięciołowski, Kowalina } \\
\text { 1971: 17, Sokołowski 1972: } \\
\text { 119, Glutz 1973: 364, Ko, Pę, } \\
\text { styczeń, marzec, kwiecień, } \\
\text { sierpień - grudzień; Oko } \\
\text { 1975: 129, 134, 136, 152, 155, } \\
\text { 156, 159, 162, 165, Cramp } \\
\text { 1980: 508, Żołnierzak 1991: } \\
\text { 21, L; Behnke 1995: 18, 39, } \\
\text { L, Pę; Mróz 2003: 49, L; } \\
\text { Kruszewicz, Manelski 2007: }\end{array}$ \\
\hline Trifolium arvense $\mathrm{L}$. & koniczyna polna & $(\mathrm{Rk}),(\mathrm{Ro}),(\mathrm{Ch})$ & $\begin{array}{r}\text { N, O, kwiecień, sierpień; } \\
\text { Oko 1975: 136, } 151\end{array}$ \\
\hline $\begin{array}{l}\text { Trifolium campestre } \\
\text { Schreb. }\end{array}$ & $\begin{array}{l}\text { koniczyna } \\
\text { różnoogonkowa }\end{array}$ & $(\mathrm{Rk}),(\mathrm{Ro}),(\mathrm{Ru})$ & N, O, kwiecień; Oko 1975 : \\
\hline
\end{tabular}




\begin{tabular}{|c|c|c|c|}
\hline Nazwa łacińska & Nazwa polska & Kategoria & Źródło \\
\hline Trifolium pratense L. & koniczyna łąkowa & $\begin{array}{l}\text { (Rk), (Ro), } \\
\text { (Rur) }\end{array}$ & $\begin{array}{r}\text { N; Oko, Gacki 1974: 160, } \\
\text { N, czerwiec; Oko 1962: } \\
\text { 20, K, Pę, luty - kwiecien,, } \\
\text { czerwiec; Oko 1975: 131, 132, } \\
134,136,143\end{array}$ \\
\hline Trifolium repens L. & koniczyna biała & $\begin{array}{l}\text { (Rk), (Ro), } \\
\text { (Ch), (Rur) }\end{array}$ & $\begin{array}{r}\text { L, Pę, kwiecień, maj, } \\
\text { sierpień; Oko 1962: 19, 22, } \\
\text { kwiecień; Ko, Pę, maj, N, O, } \\
\text { lipiec; Oko 1975: 136, 139, } \\
146\end{array}$ \\
\hline Triticum L. & pszenica & & $\begin{array}{r}\text { N; Cornau 1903: 147, Pęski } \\
\text { 1928: 19, plewy; Feil 1950: } \\
\text { 20, k, N; Popławski 1951: } \\
\text { 5, k, N; Knothe 1952: 15, } \\
\text { Dembinok 1956: 11, O; } \\
\text { Walewski, Konarski 1957: } \\
\text { 40, N; Sokołowski 1958: 146, } \\
\text { Zcz; Fedorowski 1961: 15, k, } \\
\text { pisklęta; Sikorski 1962: 15, N } \\
\text { czerwiec, lipiec, wrzesień, L. } \\
\text { marzec, Zcz, kwiecień; Oko } \\
\text { 1962: 17 - 22, k; Konarski } \\
\text { 1966: 20, N; Dzięciołowski, } \\
\text { Kowalina 1971: 17, N; } \\
\text { Sokołowski 1972: 119, k; } \\
\text { Glutz 1973: 364, Gawęcki; } \\
\text { Torgowski 1974: Gacki 1974: } \\
\text { 7, N; Lempaszak 1977: 7, } \\
\text { Cramp 1980: 507, N; Behnke } \\
\text { 1995: 18, Gorazdowski, } \\
\text { Jabłoński 2002: 33, N, śruta; } \\
\text { Mróz 2003: 96, 100,N; } \\
\text { Kruszewicz, Manelski 2007: } \\
\text { 44, 83, N; Okarma 2008: 331, }\end{array}$ \\
\hline
\end{tabular}




\begin{tabular}{|c|c|c|c|}
\hline Nazwa łacińska & Nazwa polska & Kategoria & Źródło \\
\hline Triticum vulgare Vill. & $\begin{array}{l}\text { pszenica } \\
\text { zwyczajna }\end{array}$ & (Rk), (Rur) & $\begin{array}{r}\text { N, Zcz; Oko, Gacki 1974: } \\
\text { 159, 161, Ko, N, Pę styczeń, } \\
\text { N, luty - grudzień; Oko } \\
\text { 1975: 129, 130, 132, } 134-136, \\
138,141,145,150,154,158, \\
161,164\end{array}$ \\
\hline Ulmus glabra Huds. & wiąz górski & $(\mathrm{Rk}),(\mathrm{Ro}),(\mathrm{Ru})$ & N, czerwiec; Oko 1962: 20 \\
\hline Urtica L. & pokrzywa & & $\begin{array}{r}\text { k, posiekany; Knothe 1952: } \\
\text { 14, k, pisklęta; Konarski } \\
\text { 1956: 11, Walewski, Konarski } \\
\text { 1957: 121 k, pisklęta; Sikorski } \\
\text { 1961: 3, L; Fedorowski 1961: } \\
\text { 15, k, pisklęta; Konarski } \\
\text { 1966: 24, k; Skrzypek 1981a: } \\
\text { 5, Matuszewski, Morow } \\
\text { 1994: 35, L; Kruszewicz, } \\
\text { Manelski 2007: } 46\end{array}$ \\
\hline Urtica urens L. & $\begin{array}{l}\text { pokrzywa } \\
\text { żegawka }\end{array}$ & $(\mathrm{Ch}),(\mathrm{Ru})$ & Glutz 1973: 364 \\
\hline Vaccinium L. & borówka & & Nowak 1961: 125 \\
\hline Vaccinium myrtillus L. & borówka czarna & $(\mathrm{Rk}),(\mathrm{Ru})$ & $\begin{array}{r}\text { O; Gacki 1974: 7, O; } \\
\text { Walewski, Konarski 1957: } \\
\text { 40, Bartkowiak 1970: 257, } \\
\text { Dzięciołowski, Kowalina } \\
\text { 1971: 16, Zcz; Oko, Gacki } \\
\text { 1974: 161, Cramp 1980: 507, } \\
\text { Kruszewicz, Manelski 2007: }\end{array}$ \\
\hline Vaccinium vitis -idaea $\mathrm{L}$. & $\begin{array}{l}\text { borówka } \\
\text { brusznica }\end{array}$ & $(\mathrm{Rk}),(\mathrm{Ro}),(\mathrm{Ru})$ & $\begin{array}{r}\text { O; Walewski, Konarski } \\
\text { 1957: 40, 122, Bartkowiak } \\
\text { 1970: 256, Dzięciołowski, } \\
\text { Kowalina 1971: } 16\end{array}$ \\
\hline Vaccinium uliginosum L. & $\begin{array}{l}\text { borówka } \\
\text { bagienna }\end{array}$ & $(\mathrm{Rk}),(\mathrm{Ru})$ & $\begin{array}{r}\text { O; Walewski, Konarski } \\
\text { 1957: 40, Turček 1961: 68, } \\
\text { Dzięciołowski, Kowalina } \\
\text { 1971: 16, Cramp 1980: } 507\end{array}$ \\
\hline Veronica hederifolia L. & $\begin{array}{l}\text { przetacznik } \\
\text { bluszczykowy }\end{array}$ & $\begin{array}{l}\text { (RzM), (Rk), } \\
(\mathrm{Ch}),(\mathrm{Ro})\end{array}$ & Glutz 1973: 363 \\
\hline
\end{tabular}




\begin{tabular}{|c|c|c|c|}
\hline Nazwa łacińska & Nazwa polska & Kategoria & Źródło \\
\hline Veronica chamaedrys L. & $\begin{array}{l}\text { przetacznik } \\
\text { ożankowy }\end{array}$ & (Rk), (Ro), (Ch) & $\begin{array}{r}\text { N, Zcz; Oko, Gacki 1974: } \\
160,162\end{array}$ \\
\hline Veronica persica Poir. & $\begin{array}{l}\text { przetacznik } \\
\text { perski }\end{array}$ & (Ch) & $\begin{array}{r}\mathrm{N}, \mathrm{O}, \text { maj, czerwiec, } \\
\text { grudzień; Oko 1975: 138, } \\
141,165\end{array}$ \\
\hline Viburnum lantana $\mathrm{L}$. & kalina hordowina & $(\mathrm{Rk}),(\mathrm{Ro}),(\mathrm{Ru})$ & $\begin{array}{r}\text { Turček 1961: 69, wrzesień; } \\
\text { Oko 1975: } 155\end{array}$ \\
\hline Viburnum opulus L. & kalina koralowa & $\begin{array}{l}(\mathrm{RzM}),(\mathrm{Rk}), \\
(\mathrm{Ro}),(\mathrm{Ru})\end{array}$ & $\begin{array}{r}\text { Turček 1961: 69, sierpień; } \\
\text { Oko 1975: } 151\end{array}$ \\
\hline Vicia L. & wyka & & $\begin{array}{r}\text { Dembinok 1956: 11, k; } \\
\text { Walewski, Konarski 1957: } \\
\text { 153, Ko, N, O, Pę, styczeń, } \\
\text { luty, N, O, marzec - maj, } \\
\text { sierpień - listopad, Ko, Pę, } \\
\text { grudzień; Oko 1975: 129, } \\
\text { 131, } 133 \text { - 135, 138, 151, 155, } \\
156,159,162,164\end{array}$ \\
\hline $\begin{array}{l}\text { Vicia angustifolia L. ex } \\
\text { Reichard }\end{array}$ & wyka wąskolistna & (Ch) & N, O, maj; Oko 1975: 138 \\
\hline Vicia cracca L. & wyka ptasia & (Ch) & $\begin{array}{r}\text { lipiec, listopad; Oko 1975: } \\
145,161\end{array}$ \\
\hline Vicia faba $\mathrm{L}$. & bób & & $\begin{array}{r}\text { N, O, listopad, grudzień; } \\
\text { Oko 1975: 162, 165, Rudecka } \\
\text { 1987: 16, N; Mróz 2003: } 46\end{array}$ \\
\hline Vicia hirsuta (L.) Gray & $\begin{array}{l}\text { wyka } \\
\text { drobnokwiatowa }\end{array}$ & (Ch) & $\begin{array}{r}\text { N, Zcz; Oko, Gacki 1974: } \\
\text { 160, 162, Glutz 1973: 364, N; } \\
\text { Gacki 1974: 7, N, O, marzec, } \\
\text { październik, listopad; Oko } \\
\text { 1975: 133, 158, } 161\end{array}$ \\
\hline Vicia sativa L. & wyka siewna & (Rk), (Rur) & $\begin{array}{r}\text { N, O, styczeń - marzec, } \\
\text { wrzesień, grudzień, Ko, Pę; } \\
\text { Oko 1975: 129, 130, 133, 139, } \\
155,164\end{array}$ \\
\hline $\begin{array}{l}\text { Vicia tetrasperma (L.) } \\
\text { Schreb. }\end{array}$ & $\begin{array}{l}\text { wyka } \\
\text { czteronasienna }\end{array}$ & (Ch) & $\begin{array}{r}\text { N; Gacki 1974: 7, N; Oko, } \\
\text { Gacki 1974: 160, N, O, } \\
\text { kwiecień, październik; Oko } \\
\text { 1975: 135, } 158\end{array}$ \\
\hline
\end{tabular}




\begin{tabular}{|c|c|c|c|}
\hline Nazwa łacińska & Nazwa polska & Kategoria & Źródło \\
\hline Vicia villosa Roth. & wyka kosmata & $(\mathrm{RzM}),(\mathrm{Ch})$ & $\begin{array}{r}\text { N; Oko, Gacki 1974: 160, N, } \\
\text { luty, marzec, październik } \\
- \text { grudzień; Oko 1975: 131, } \\
\text { 133, 158, 161, } 164\end{array}$ \\
\hline Viola L. & fiołek & & sierpień; Oko 1975: 150 \\
\hline Viola arvensis Murray & fiołek polny & $(\mathrm{Ch})$ & $\begin{array}{r}\text { N, lipiec, sierpień, } \\
\text { październik - grudzień; Oko } \\
\text { 1975: 146, 150, 158, 161, 164, } \\
\text { N; Lempaszak 1977: }\end{array}$ \\
\hline Viola tricolor $\mathrm{L}$. & fiołek trójbarwny & $(\mathrm{Ch}),(\mathrm{Ru}),(\mathrm{Ro})$ & czerwiec; Oko 1975: 142 \\
\hline Viscum album $\mathrm{L}$. & jemioła pospolita & $(\mathrm{Rk}),(\mathrm{Ru})$ & $\begin{array}{r}\text { Turček 1961: 70, Bartkowiak } \\
\text { 1970: } 259 \\
\end{array}$ \\
\hline Vitis L. & winorośl & & $\begin{array}{r}\text { Gorazdowski, Jabłoński } \\
\text { 2002: } 33\end{array}$ \\
\hline Vitis vinifera $\mathrm{L}$. & $\begin{array}{l}\text { winorośl } \\
\text { właściwa }\end{array}$ & $\begin{array}{l}\text { (Rk), (Ro), } \\
\text { (Rur) }\end{array}$ & $\begin{array}{r}\text { Turček 1961: 71, Bartkowiak } \\
\text { 1970: } 255\end{array}$ \\
\hline Zea L. & kukurydza & & $\begin{array}{r}\text { N; Cornau 1903: 147, Feil } \\
\text { 1950: 20, k, N; Knothe 1952: } \\
\text { 15, Dembinok 1956: 11, N; } \\
\text { Walewski, Konarski 1957: } \\
\text { 40, N; Sokołowski 1958: } \\
\text { 146, Nowak 1961: 125, k, } \\
\text { tłuczona; Sikorski 1962: 7, } \\
\text { k; Konarski 1966: 20, N; } \\
\text { Dzięciołowski, Kowalina } \\
\text { 1971: 17, N; Sokołowski } \\
\text { 1972: 119, N; Pomarnacki } \\
\text { 1974: 5, Cramp 1980: 507, } \\
\text { Pielowski 1984: 13, Rudecka } \\
\text { 1987: 16, N; Dudziński 1988: } \\
\text { 121, N; Behnke 1995: 18, } \\
\text { Łogin 1995: 12, Kamieniarz } \\
\text { 1999: 15, Gorazdowski, } \\
\text { Jabłoński 2002: 33, N; Mróz } \\
\text { 2003: 46, 49, N; Kruszewicz, } \\
\text { Manelski 2007: 83, N; } \\
\text { Okarma 2008: 331 }\end{array}$ \\
\hline
\end{tabular}




\begin{tabular}{|c|l|l|r|}
\hline Nazwa łacińska & \multicolumn{1}{|c|}{ Nazwa polska } & \multicolumn{1}{|c|}{ Kategoria } & \multicolumn{1}{c|}{ Źródło } \\
\hline Zea mays L. & kukurydza & (Rk), (Ro), & Bk, L, N; Walewski, \\
& zwyczajna & (Rur) & Konarski 1957: 41, 74, \\
& & 121, Nowak 1961: 125, L; \\
& & Dzięciołowski, Kowalina \\
& & & 1971: 17, Glutz 1973: 364, N; \\
& & & Gacki 1974: 7, N; Oko, Gacki \\
& & & 1974: 159, N, listopad; Oko \\
& & & 1975: 161, JD \\
\hline
\end{tabular}

Źródło: opracowanie własne

\section{Literatura - Aneks}

Bartkowiak S., 1970, Ornitochoria rodzimych i obcych gatunków drzew i krzewów, Arboretum Kórnickie, XV, s. 237-261.

Bednorz J., Bogucki Z.,1961, Ptaki pomocnikami rolnika, Ludowa Spółdzielnia Wydawnicza, Warszawa.

Behnke H.,1995, Kuraki polne: bażant i kuropatwa - hodowla i wsiedlanie, Wydawnictwo Świat, Warszawa.

Biały K., 1989, Wolierowe przetrzymywanie kuropatw i wypuszczanie w łowisko, Łowiec Polski, 1, s. 10 .

Biały K., 1997, Kuropatwa szara - ochrona w warunkach zimowego zagrożenia, Łowiec Polski, 12, s. $20-23$.

Bobrowicz G., 1996, Gdy jabłka opadaja..., Łowiec Polski, 11, s. 35.

Bochniarzowa M.,1974, Kapusta pastewna - cenna zielona karma zimowa, Łowiec Polski, 8 (14647), s. 16-30.

Bujna Cz., 1958, Pożyteczność i znaczenie kuropatw dla gospodarki rolnej, Pomorsko-Poznański Biuletyn Łowiecki, 46 s. 28-30.

Buksiński R., 1958, Topinambur, Pomorsko-Poznański Biuletyn Łowiecki, 44, s. 40-48.

Chlewski A.,1970, Zimowanie kuropatw w wolierach, Łowiec Polski, 18 (1381), s. 6-7.

Cramp S., 1980, Handbook of the Birds of Europe, the Middle East and North Africa, 5. Oxford University Press, New York.

Cronau C., 1903, Bażant łowny, jego pokrewne gatunki i i krzyżowania. Historya i hodowla bażantów oraz zakładanie bażantarni, Nakładem Redakcyi Łowca Polskiego, Warszawa. 
Chojnowski A., 2011, Niedoceniona kapusta, Łowiec Polski, 6, s. 58-59.

Dejonghe J.F., 2008, Ptaki w swoim środowisku, Zakład Narodowy im. Ossolińskich, Warszawa, Wrocław, Kraków.

Dembiniok E., 1956, Dokarmianie bażantów, Łowiec Polski, 8-9 (1053-4), s.11.

Dudziński W., 1988, Ptaki łowne, Państwowe Wydawictwo Rolnicze i Leśne, Warszawa.

Dzięciołowski R., 1961, Z angielskich badań nad kuropatwa, Łowiec Polski, 2 (1149), s. 3-4, 14.

Dzięciołowski R., 1964, Z angielskich badań nad ptactwem łownym, Łowiec Polski, 3 (1222), s. 7, 15.

Dzięciołowski R., Kowalina E.,1971, Bażant: hodowla i użytkowanie, Państwowe Wydawictwo Rolnicze i Leśne, Warszawa.

Dzieduszycki E.,1968, Jak podnieść stan kuropatw w łowisku, Łowiec Polski, 23-24 (1338-1339), s. 23-24.

Fedorowski W.,1961, Rola witamin w hodowli bażantów, Łowiec Polski, 8 (1155), s. 4-5, 15.

Fedorowski W.,1963, Jak poprawić lęgi bażantów, Łowiec Polski, 23-24 (1218-19), s. 10-11.

Feil R., 1950, Opiekujemy się bażantem, Łowiec Polski, 6 (979), s. 19-20.

Feil R., 1989, Jeszcze o kuropatwach, Łowiec Polski, 6, s. 24.

Frankiewicz E.,1950, Hodowla przepiórek, Łowiec Polski, 9 (982), s. 18-19.

Frankiewicz E.,1952, Ochrona kuropatw na przedwiośniu, Łowiec Polski, 2 (999), s. 3.

Gacki J., 1974, Skład pożywienia bażanta w okresie jesienno-zimowym (na przykładzie województwa poznańskiego), Łowiec Polski, 19 (1478), s. 7.

Gawęcki K., Torgowski J.,1974, Badania nad żywieniem bażantów (1). Żywienie stada podstawowego, Łowiec Polski, 20 (1479), s. 6.

Glutz von Blotzheim Urs N. (Hrsg.) 1973, Handbuch der Vogel Mitteleuropas, 5. Akademische Verlaggesellschaft, Frankfurt am Main.

Głębocki B., 2010, Pogoda dla kuropatwy, Łowiec Polski, 10, s. 34-37.

Gorazdowski M.J., Jabłoński K.M., 2002, Bażanty i pawie, Agencja Wydawnicza Egros, Warszawa. Jabłoński K.M., Gorazdowski M.J., 2004, Przepiórki i kuropatwy, Agencja Wydawnicza Egros, Warszawa.

Jeleniak R., 2002, Żarnowiec-roślina pożyteczna, Łowiec Polski, 6 (1873), s. 21.

Jonkisz O.,1931, Hodowla bażantów w zamknięciu, Odb: Drób Polski, 10.

Kaj J., 1961, Wartość topinamburu w dokarmianiu zwierzyny, Zachodni Poradnik Łowiecki, Rok II, 1, s. 30-36. 
Kamieniarz R., 1999, Bażant gospodarowanie populacja, Łowiec Polski, 6 (1837), s. 13-16.

Knothe H.,1952, Praktyczne wskazówki wychowu bażantów, Łowiec Polski, 5 (1002), s. 14-15.

Knothe H.,1952a, Pielegnacja kuropatw po sezonie polowań na kuropatwy, Łowiec Polski, 10 (1007), s. 8 .

Konarski S., 1956, Hodowla bażantów w PGR, Łowiec Polski, 8-9 (1053-4).

Konarski S., 1966, Półzamknięta hodowla bażantów, Zachodni Poradnik Łowiecki, Rok VII, 3, s. $18-25$.

Kopijowska J., 1961, Jak chronić przyrodę w szkolnym kole ochrony przyrody, Nasza Księgarnia, Warszawa.

Kruszewicz A., Manelski B., 2007, Bażanty Gatunki, pielęgnacja, choroby, Multico Oficyna Wydawnicza, Warszawa.

Kryspin M.R., 1955, Na przykładzie badań nad kuropatwa (O dorobek naukowy łowiectwa), Łowiec Polski, 9 (1042), s. 4-5.

Lempaszak U., 1977, Co jedza bażanty?, Łowiec Polski, 21, s. 7.

Luniak M., 1965, Ptaki zimujące w naszym kraju, Przyroda Polska, Rok IX, 2, s. 5.

Łogin M., 1995, Bażant, Łowiec Polski, 12, s. 12-13.

Łukasik Ł., 1996, Bażant, Wszechświat, 97, 10, s. 234.

Madej M., 2007, Ptaki łatwe i pewne rozpoznawanie, Firma Księgarska Jacek i Krzysztof Oleksiejuk, Ożarów Mazowiecki.

Matuszewski G., Morow K., 1994, Kuraki leśne. Wademekum myśliwego 4, Oficyna Edytorska Wydawnictwo Świat, Warszawa.

Matysek W., 2010, Sposób na bażanty, Łowiec Polski, 2, s. 42-45.

Meisnerowski S., 1961, Kuropatwa, Zachodni Poradnik Łowiecki, 3, s. 25-32.

Moraczewska Z., 1955, Z badań nad kuropatwa w ČSR, Łowiec Polski, 2 (1035), s. 6.

Mróz E., 2003, Bażanty, Multico Oficyna Wydawnicza, Warszawa.

Nowak E., 1961, Ptaki pomocnikami rolnika, Ludowa Spółdzielnia Wydawnicza, Warszawa.

Okarma H., Tomek A., Bonczar Z., 2008, Łowiectwo, Wydawnictwo Edukacyjno Naukowe H2O, Kraków.

Oko Z., 1962, Składniki pożywienia kuropatw dorostych (Perdix perdix L.) w okresie wiosny i lata w świetle wyników badań prowadzonych na terenie województwa poznańskiego, Zachodni Poradnik Łowiecki, III, 2, s. 16-23. 
Oko Z., 1962a, Skład pożywienia kuropatwy (Perdix perdix L.) w miesiacach jesiennych $i$ zimowych w województwie poznańskim, Zachodni Poradnik Łowiecki, III, 3, s. 24-33.

Oko Z.,1963, Badania nad składem pożywienia młodych kuropatw Perdix perdix (L.), Przegląd Zoologiczny, VII, 4, s. 337-342.

Oko Z., Gacki J., 1974, Skład jakościowy i ilościowy pożywienia bażanta łownego (Phasianus colchicus) w okresie jesienno-zimowym na terenie województwa poznańskiego, Ornitologia stosowana, LXX.

Oko Z., Wójtkowski F.,1960, Z tymczasowych badań nad składem pożywienia kuropatwy. Perdix perdix, Przegląd Zoologiczny, IV, 4, s. 316-320.

Ortwein L.,1964, Topinambur - cenna roślina w gospodarstwie łowieckim, Las Polski, 19.

Panek M., 1987, Życie kuropatw i przyczyny spadku ich liczebności, Łowiec Polski, 10, s. 6-8.

Panek M., 1988, Nie tylko budki, Łowiec Polski, 4, s. 15.

Pęski L., 1928, Hodowla bażantów, Wydawnictwo Wydziału Leśnictwa Pomorskiej Izby Rolniczej w Toruniu, Toruń.

Pielowski Z., 1984, Bażant w łowisku i hodowli, Łowiec Polski, 6, s. 10-13.

Pilarczyk J., 1987, Sadźmy topinambur, Łowiec Polski, 2, s. 28.

Pilarczyk J., 2006, Sierpień spichlerz dla zwierzyny, Łowiec Polski, 8 (1923), s. 48.

Pomarnacki L.,1955, Z badań nad kuropatwa, Łowiec Polski, 4 (1037), s. 6-7.

Pomarnacki L., 1958, Pomóżmy kuropatwom, Przyroda Polska, 1i 2 II, s. 7.

Pomarnacki L., 1965, Obserwacje nad kuropatwami na kielecczyźnie, Notatki Ornitologiczne, VI, 2, s. 30-32.

Pomarnacki L., 1969, Kuropatwy prosza o pomoc, Przyroda Polska, XII, s. 14.

Popławski L., 1951, Wychów bażantów ze sprowadzonych jaj, Łowiec Polski, 5 (990), s. 4-5.

Popławski L., 1962, Kuropatwa Monografia Przyrodniczo-Łowiecka, Państwowe Wydawnictwo Rolnicze i Leśne, Warszawa.

Rudecka J., 1987, Wpływ pokarmu na przeżywalność i rozmieszczenie bażanta, Łowiec Polski, 7-8, s. 16.

Sikorski J., 1961, Hodowla bażanta w ośrodkach PZŁ, Łowiec Polski, 17 (1164), s. 2-3.

Sikorski J., 1962, Wychów bażantów w kole łowieckim, Łowiec Polski, 5 (1176), s. 6-7, 15.

Sikorski J., 1963, Odłowy i zimowanie kuropatw, Łowiec Polski, 23-24 (1218-19), s. 3-5.

Sikorski J., 1965, Jeszcze o hodowli bażantów, Łowiec Polski, 2 (1245), s. 3,6.

Skrzypek R., 1981, Witaminy i składniki mineralne w reprodukcji bażantów. Cz. I. Witaminy, Łowiec Polski, 11-12, s. 10. 
Skrzypek R., 1981a, Witaminy i składniki mineralne w reprodukcji bażantów. Cz. II. Składniki mineralne, Łowiec Polski, 13-14, s. 5.

Sokołowski J., 1958, Ptaki ziem polskich, t. 2, Państwowe Wydawnictwo Naukowe, Warszawa. Sokołowski J., 1972, Ptaki ziem polskich, t. 2, Państwowe Wydawnictwo Naukowe, Warszawa. Stankiewicz M., 2000, Drzewa i krzewy w łowisku (2), Łowiec Polski, 5 (1848), s. 25-26.

Stankiewicz M., 2000a, Drzewa i krzewy w łowisku (2), Łowiec Polski, 5 (1848), s. 26-25.

Staszek S., 1961, Ratowanie wykoszonych gniazd kuropatw i bażantów oraz wychów piskląt, Zachodni Poradnik Łowiecki, II, 2, s. 12-19.

Stokowski A., 1952, O hodowli bażanta na dziko, Łowiec Polski, 4 (1001), s. 8.

Strojny W., 1986, Nasze zwierzęta, Państwowe Wydawnictwo Rolnicze i Leśne, Warszawa.

Szederjei M., 1958, Gospodarcze znaczenie kuropatwy i bażanta, Łowiec Polski, 22 (1097), s. 13.

Szczepkowski J.J., 1953, Składniki pożywienia kuropatw, Łowiec Polski, 6 (1015), s. 88-89.

Szczepkowski J., 1958, Wychów kuropatw z jaj, Łowiec Polski, 10 (1085), s. 4.

Taczanowski W., 1882, Ptaki krajowe, t.1, Wydawnictwo Akademii Umiejętności w Krakowie, Kraków.

Turček F., 1961, Ökologische beziehungen der Vögel und gehölze. Vydavatel'stvo slovenskey akadémie vied, Bratislava.

Walewski W., Konarski S., 1957, Bażanty, Państwowe Wydawnictwo Rolnicze i Leśne, Warszawa. Wielbo E., Dziedzic R., 1974, Odchów bażantów w OHZ Wierzchowiska w 1973, Łowiec Polski, 8 (1468), s. 6.

Wiktor S., 1905, Kuropatwa, Redakcja Łowca Polskiego, Warszawa.

Żołnierzak S., 1991, Hodowca radzi, Łowiec Polski, 11, s. 19-24. 


\section{Changes in the rural landscape of Mazovia and their impact on recreational values of the landscape due to the presence of Phasianidae birds}

\section{ABSTRACT}

The article attempts to show how activities at the planning and agricultural level affect the recreational values of the landscape caused by the behavior of Phasianidae birds. This goal was achieved on the example of three species connected with agrocenoses: partridges, quails and pheasants. In particular, food availability and the habitat of life were taken into account. The changes and their causes were analyzed in the context of both Poland and Mazovia. The selected ones that significantly influence the current quantitative structure of the discussed bird species, are: the structure of agricultural land use, chemization, fertilization and mechanization. The deductive methods used in landscape architecture were used to achieve the main goal and intermediate goals realized at individual stages of the work. Hypotheses, which were verified by analysing the literature in a specific aspect, were put forward. The main tested hypothesis was to determine, whether the progress in agriculture (taking into account the multifunctional use of the landscape) supported by planning methods, can contribute to the development of the recreational values of the landscape due to the protection of Phasianidae birds. It was confirmed that activities at the planning level do not meet the needs related to the protection of these species. The analysis of the connections and dependencies between humans, animal species and their environment, has shown that they can be both positive and negative in each case under consideration. The comparison of the period between 1990 and 2017 confirmed the progressive intensification of agriculture. Tabulated summary of plant food shows that the grouses eat 247 various kinds of plants (17 of which provide nourishment for three grouse species, and 55 for two). The division of plants into categories showed that the major feeding grounds for partridges and pheasants are landscape plants $(55 \%, 49.7 \%)$, useful plants $(50.5 \%, 57,4)$ and ornamental plants $(39.3 \%, 42 \%)$. Nourishment for quails consists of weeds $(56.3 \%)$, useful plants $(41.8 \%)$ and endangered plant species of Mazovia (32\%). In the case of partridges and pheasants, weeds constituted $38.2 \%$ and $29.4 \%$ of eaten plants and endangered plant species over $14 \%$. Agricultural crops constituted $23.5 \%$ of feeding grounds among partridges, $18.1 \%$ among quails and $14.4 \%$ among pheasants. In response to the problems mentioned above, the authors recognize the need for designing individual landscape and spatial models for individual municipalities. In the case of partridges these models should take into account, in particular, the band arrangement of subzones. They should also provide shelters, nesting places and feeding grounds.

Key words: landscape and spatial models, rural landscape, leisure, plant food, quail, partridge, pheasant 
I. Analizy i Studia / Analyses and Studies

Karolina Pietrzykowska, mgr inż. arch. kraj., absolwentka kierunków Architektura Krajobrazu, Ochrona Środowiska, Ochrona i Konserwacja Zabytkowych Założeń Ogrodowych, Pedagogika i Biologia na następujących uczelniach: Wyższa Szkoła Ekologii i Zarzq̨dzania, Szkoła Główna Gospodarstwa Wiejskiego, Uniwersytet Warszawski, Uniwersytet Łódzki. Zawodowo zwiq̨ana z ochrona środowiska i Wyższą Szkołą Ekologii i Zarządzania. Współautorka artykułów poświęconych problematyce ptaków i architektury krajobrazu m.in. „Drzewa i krzewy jako źródło pożywienia ptaków drozdowatych”, "Selected aspects of the process of landscaping the historic Park in Piekarty, Poland". Członek sekcji ornitologicznej PAN.

Karolina Pietrzykowska, MA, Eng, graduate of Landscape Architecture, Environmental Protection, Protection and Conservation of Historic Garden Assumptions, Pedagogy and Biology at the following universities: the University of Ecology and Management, the Warsaw University of Life Sciences, the Warsaw University, the University of Lodz. Professionally connected with environmental protection and the University of Ecology and Management. Co-author of articles on birds and landscape architecture, i.a. "Trees and shrubs as a source of food for thrush birds", "Selected aspects of the process of shaping the historical landscape of the park in Piekarty, Poland". Member of the ornithological section of the Polish Academy of Sciences.

Jerzy Wojtatowicz, dr inż. arch. kraj., absolwent i wieloletni pracownik naukowy Katedry Architektury Krajobrazu Szkoły Głównej Gospodarstwa Wiejskiego w Warszawie. Od 1997 r. pracownik Wyższej Szkoły Ekologii i Zarządzania w Warszawie, (w latach 2000-2014 Dziekan Wydziału Architektury), od 1995 r. współwłaściciel pracowni projektowej Aster-Park, współautor książki „Ptaki w ogrodzie”, redaktor naukowy ksiq̨żek: "Warszawska Przyroda. Obszary i obiekty chronione”, „Przyroda Warszawy” oraz współautor rozdziału "Zespoły przyrodniczo-krajobrazowe i tereny użytku ekologicznego" w monografii „Przyroda Bielan warszawskich".

Jerzy Wojtatowicz, PhD, Eng in Landscape Architecture. Graduate and long-term faculty member at the Department of Landscape Architecture at the Warsaw University of Life Sciences (SGGW). Since 1997, associated with the University of Ecology and Management in Warsaw, Dean of the Faculty of Architecture between 2000 and 2014. Co-owner of the Aster-Park design studio since 1995. Co-author of "Birds in the garden" and a monograph entitled "Nature in the Bielany District of Warsaw". Science editor of publications: "Warsaw's Nature. Protected sites and areas" and "Nature of Warsaw". 